\title{
Microeconomic Analyses of the Causes and Consequences of Political Violence
}

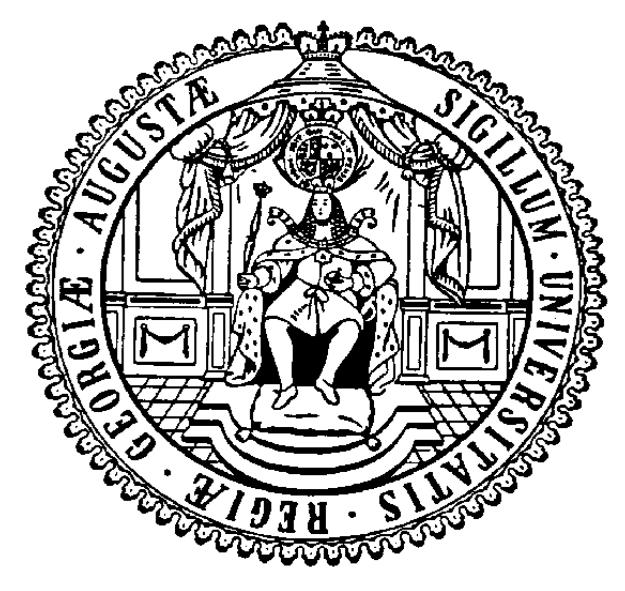

Dissertation zur Erlangung des wirtschaftswissenschaftlichen Doktorgrades der Wirtschaftswissenschaftlichen Fakultät der Universität Göttingen 


\section{Prüfungskommission:}

Erstgutachter:

Zweitgutachter:

Drittgutachter:

Tag der Disputation:
Prof. Stephan Klasen, Ph.D.

Prof. Dr. Axel Dreher

Prof. Dr. Martin Gassebner

22. Mai 2015 


\section{Danksagung}

Es ist also vollbracht, nach drei Jahren im Graduiertenkolleg 'Globalisierung und Entwicklung' an der Universität Göttingen kann ich durch die Seiten der fertigen Dissertation blättern. Ich möchte meinen beiden Betreuern, Stephan Klasen und Axel Dreher, danken für ihre fachliche Unterstützung, die Möglichkeit zu Feldforschung und Teilnahme an Konferenzen, aber auch für das persönliche Mentoring. Ich habe sehr viel gelernt in den letzten drei Jahren und wusste immer, dass die Tür offen steht, egal mit welcher Frage ich vorbeikomme. Vielen Dank auch an Martin Gassebner für seine Bereitschaft, als Drittprüfer zu fungieren.

Aber auch Kollegen, die inzwischen Freunde sind, haben diese Zeit geprägt. Ohne Mensaanrufe um 11.30 Uhr, Ausflüge am Wochenende und leckere, internationale Kochabende wäre die Promotion eine deutlich weniger bereichernde Zeit gewesen. Auch den Freunden in der Ferne ein großes Dankeschön, dass ich immer erzählen (und manchmal auch nörgeln) durfte!

Ein großer Dank gilt auch meiner Familie, die mich schon immer meinen eigenen Weg gehen lässt und mich darin unterstützt, meine Ziele zu erreichen.

Steffen, 'words... don't come easy': Danke! Für Statabefehle, Korrekturlesen, stete Ablenkung und Aufmunterung und die starke Schulter (in zunehmender Wichtigkeit)!

Merle Kreibaum

Göttingen, im April 2015 


\section{Table of Contents}

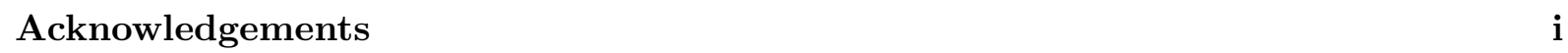

List of Abbreviations $\quad$ iv

List of Figures $\quad$ v

List of Tables $\quad$ vi

1 Introduction 1

1.1 Synopsis of Chapter 1: Weapon of Choice . . . . . . . . . . . . . . 3

1.2 Synopsis of Chapter 2: Their Suffering, Our Burden? How Congolese Refugees Affect the Ugandan Population . . . . . . . . . . . . . . . . . . . . . . 4

1.3 Synopsis of Chapter 3: Missing Men: Differential Effects of War and Socialism on Female Labour Force Participation in Vietnam . . . . . . . . . . . . . . 5

2 Weapon of Choice $\quad 6$

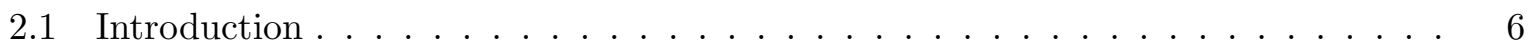

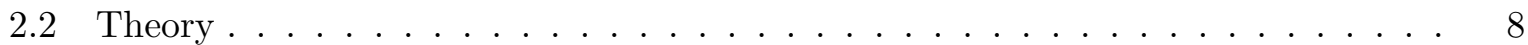

2.3 Method and Data. . . . . . . . . . . . . . . . . 12

2.4 Results . . . . . . . . . . . . . . . . . . . . . 17

2.4 .1 Tests for Robustness . . . . . . . . . . . . . . . . . . . 23

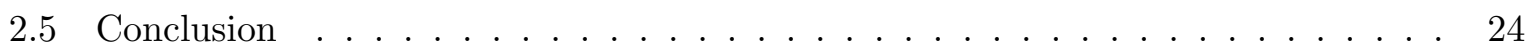

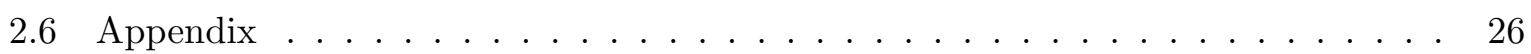

3 Their Suffering, Our Burden? How Congolese Refugees Affect the Ugandan $\begin{array}{ll}\text { Population } & 30\end{array}$

3.1 Introduction . . . . . . . . . . . . . . . . . . . . . 30

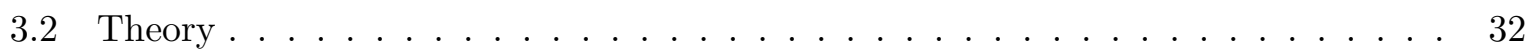

3.3 Refugees in Uganda . . . . . . . . . . . . . . . . . . . . 35

3.4 Data and Analysis . . . . . . . . . . . . . . . . . . 40

3.4 .1 Identification . . . . . . . . . . . . . . . . . . 44

3.4 .2 Model . . . . . . . . . . . . . . . . . . . 46

3.4 .3 Findings . . . . . . . . . . . . . . . . . . . . . . . . 47

3.4.4 Discussion and Robustness . . . . . . . . . . . . . . . . . 51

3.4.5 Instrumental Variable Approach . . . . . . . . . . . . . . . . . . . 52

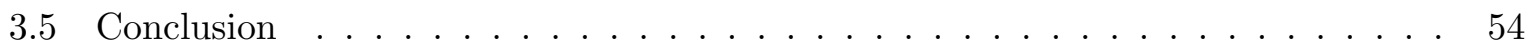




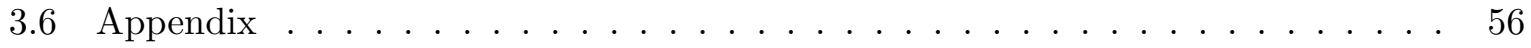

4 Missing Men: Differential Effects of War and Socialism on Female Labour

$\begin{array}{ll}\text { Force Participation in Vietnam } & 66\end{array}$

4.1 Introduction . . . . . . . . . . . . . . . . . . . . 66

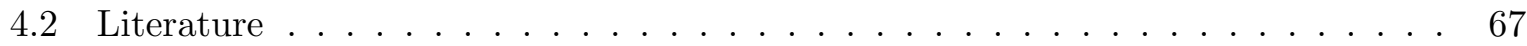

4.3 Model . . . . . . . . . . . . . . . . . . . . . . . 70

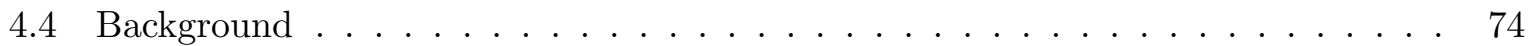

4.5 Empirical Analysis . . . . . . . . . . . . . . . . . . . . . . 75

$4.5 .1 \quad$ Data . . . . . . . . . . . . . . . . . . . . 76

4.5.2 Model and Findings . . . . . . . . . . . . . . . . . . . . . . . 79

4.5.3 The North-South Divide . . . . . . . . . . . . . . . . . . . . . . . 82

4.5.4 Tests for Robustness . . . . . . . . . . . . . . . . . . . 83

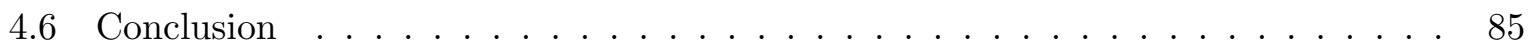

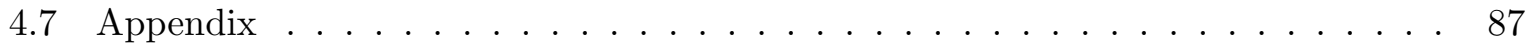

$\begin{array}{lr}\text { Bibliography } & 91\end{array}$

Eidesstattliche Erklärung viii 


\section{List of Abbreviations}

2SLS

ACLED

BSS

DAR

DRC

EPR

FLFP

FLFPR

GDP

IDP

IV

MAROB

MENA

NOAA

NGO

OLS

PPP

PRIO

SRS

UBOS

UGX

UNHCR

UNHS

USA

WFP

WVS

WWII
Two-stage Least Squares

Armed Conflict Location and Event Data

Behavioural Surveillance Survey

Development Assistance for Refugee-Hosting Areas

Democratic Republic of the Congo

Ethnic Power Relations Database

Female Labour Force Participation

Female Labour Force Participation Rate

Gross Domestic Product

Internally Displaced Person

Instrumental Variable

Minorities at Risk Organizational Behavior Database

Middle East and North Africa

National Oceanic and Atmospheric Administration

Non-Governmental Organisation

Ordinary Least Squares

Purchasing Power Parities

Peace Research Institute Oslo

Self-Reliance Strategy

Ugandan Bureau of Statistics

Ugandan Shillings

United Nations High Commissioner for Refugees

Ugandan National Household Survey

United States of America

World Food Programme

World Values Survey

World War II 


\section{List of Figures}

$3.1 \quad$ UNHCR Presence in Uganda as of July 2012 (Note: Rwamwanja settlement was only opened in 2012; Source: UNHCR website, accessed April 2nd, 2014) 37

$3.2 \quad$ Number of newly arriving refugees by settlement, 1990-2011 . . . . . . . 44

$4.1 \quad$ Share of Female Population by Province, $1979 \ldots \ldots \ldots$. . . . . . 78

$4.2 \quad$ Marginal Effects Across Cohorts, Including 95\% Confidence Intervals . . . . 82

$4.3 \quad$ Region Fixed Effects $($ North $=$ Black $) \ldots \ldots \ldots \ldots$

$4.4 \quad$ Distribution of Conflict Intensity . . . . . . . . . . . . . . . . . 84

C1 Marginal Effects Across Cohorts, Averaging Over Three Provinces, Including $95 \%$ Confidence Intervals . . . . . . . . . . . . . . . . . . . . 90 90

C2 Marginal Effects Across Cohorts, Dropping Quang Ninh Province, Including $95 \%$ Confidence Intervals . . . . . . . . . . . . . . . . . . . . 90 


\section{List of Tables}

2.1 Determinants of Terror and Insurgency, Multinomial Logit, 1980-2004 _ . 18

2.2 Determinants of Terror and Insurgency, Multinomial Logit, 1980-2004, Political Participation . . . . . . . . . . . . . . . . . 20

2.3 Determinants of Terror and Insurgency, Multinomial Logit, 1980-2004, Autonomy and Economic Discrimination . . . . . . . . . . . . 22

2.4 Determinants of Terror and Insurgency, Multinomial Logit, 1980-2004, Support by Foreign State . . . . . . . . . . . . . . . . . . . . . . 23

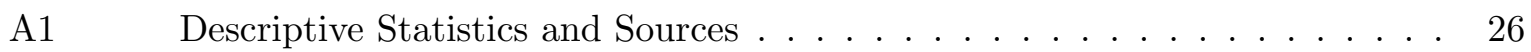

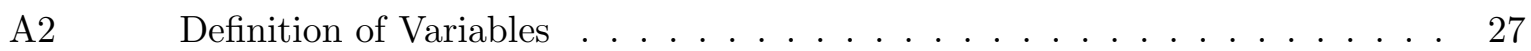

A3 Determinants of Peace and Insurgencies, Multinomial Logit, 1980-2004, Alternative Oil Measure . . . . . . . . . . . . . . . . 28

A4 Determinants of Peace and Insurgencies, Multinomial Logit, 1980-2004, Alternative Specifications/ Covariates . . . . . . . . . . . . . 29

$3.1 \quad$ Absolute and relative number of refugees, $2002-2010 \ldots \ldots \ldots$

$3.2 \quad$ Descriptive Statistics UNHS, at the Household and Community Level . . . . 41

$3.3 \quad$ Descriptive Statistics Afrobarometer, at the Household Level . . . . . . . . 41

3.4 District Characteristics in 1992, at the Household Level, Including t-Test . . 45

3.5 Refugee Presence and District Characteristics in $1992 \ldots \ldots$. . . . . . . 46

3.6 Household Consumption by Main Income Source, Linear Probability Models,

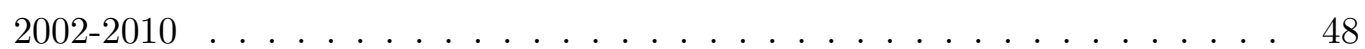

3.7 Public and Private Health Services in Community, Linear Probability Mod-

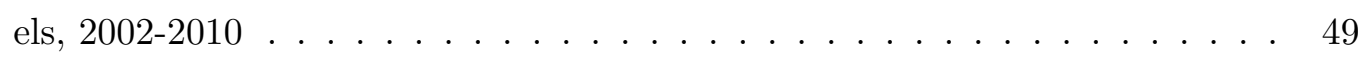

3.8 Public and Private Primary Education in Community, Linear Probability

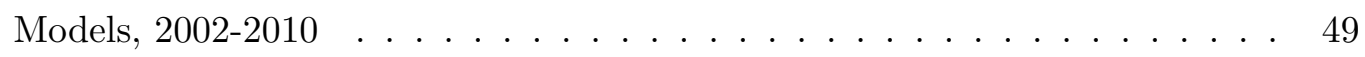

$3.9 \quad$ Households' Perceptions, Linear Probability Models, 2002-2010 _ . . . . . . 50

3.10 Instrumental Variable Approach, 2SLS Models, Second Stage, 2002-2010

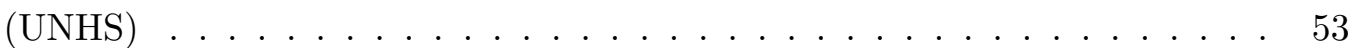

3.11 Instrumental Variable Approach, 2SLS Models, Second Stage, 2002-2010 (Afrobarometer) . . . . . . . . . . . . . . . . . 5 53

B1 Reduced Models for All Outcome Variables, Linear Probability Models, $2002-2010 \ldots \ldots \ldots \ldots \ldots \ldots \ldots \ldots$

3.2 Household Welfare by Main Income Source, Displaying Control Variables, Linear Probability Models, 2002-2010 . . . . . . . . . . . . . . . . . 57 
3.3 Public and Private Health Service Provision, Displaying Control Variables, Linear Probability Models, 2002-2010 _ . . . . . . . . . . . . . 58

3.4 Public and Private Primary Education, Displaying Control Variables, Linear Probability Models, 2002-2010 _ . . . . . . . . . . . . . . . . . . . 59

3.5 Households' Perceptions, Displaying Control Variables, Linear Probability

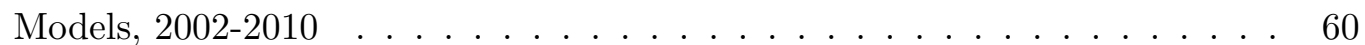

3.6 Replacing Refugee Levels with the M-V Indicator, Linear Probability Mod-

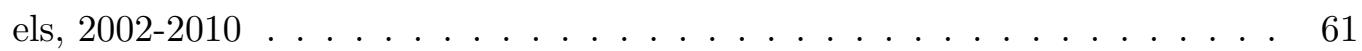

3.7 District Level Analysis, Linear Probability Models, 2002-2010 . . . . . . . . 62

3.8 Replacing Refugee Levels with an Instrumental Variable, Two-Stage Least Squares (2SLS) Models, 2002-2010 (Consumption and Health Service Provi-

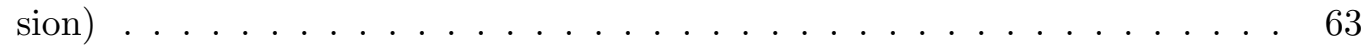

3.9 Replacing Refugee Levels with an Instrumental Variable, Two-Stage Least Squares (2SLS) Models, 2002-2010 (Primary School Provision) . . . . . . . . 64

3.10 Replacing Refugee Levels with an Instrumental Variable, Two-Stage Least Squares (2SLS) Models, 2002-2010 (Households' Perceptions) . . . . . . . . 65

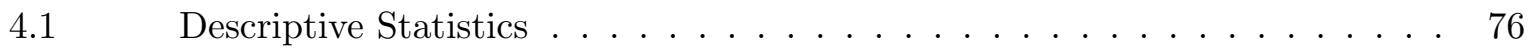

4.2 Determinants of Women's Choice to Work, Probit Models, 1989-2009 . . . . 81

C1 Descriptive Statistics by Census Wave . . . . . . . . . . . . . . . 87

C2 Determinants of Women's Choice to Work, Probit Models, 1989-2009, Including Cohort Interaction Effects . . . . . . . . . . . . . . . . . . 88

C3 Determinants of Women's Choice to Work: Robustness Checks, Probit Mod-

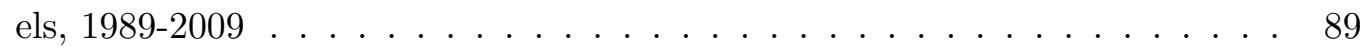




\section{Introduction}

'Most nations have experienced an internal armed conflict since 1960. Yet while civil war is central to many nations' development, it has stood at the periphery of economics research.'

Blattman and Miguel (2010):1

Violent conflict is common among the poorest countries and clearly one of the most important barriers to growth, destroying physical, human, and social capital, often in the long run. At the same time, it is a development 'trap' that is not easy to escape from as poverty has also been found to be one of the most important determinants of civil war (Collier 2008). Currently, 1.5 billion people live in areas affected by fragile statehood, conflict, or large-scale organised criminal violence - no low-income fragile or conflict-affected country has yet achieved a single Millennium Development Goal (World Bank 2011a). Each year over the course of the last decades, an average of two new civil wars broke out, creating a cost of approximately 100 billion US dollars - or double the aid budget (Collier 2008). In 2012, 14.5 million people lived abroad as refugees and 37,992 people were counted as battle-related deaths (World Bank 2015). These few descriptive numbers underline the human and economic harm that political violence brings about and hence the importance of understanding in detail its causes and consequences.

In the beginning of the 2000s, economics research began to address the determinants of (civil) war, namely in the form of the seminal cross-country analyses by Collier and Hoeffler (1998, 2004) and Fearon and Laitin (2003). ${ }^{1}$ These authors find similar factors driving the occurrence of violent conflicts, such as poor economic performance, ethnic diversity, the 'natural resource curse', and a larger share of young men who can potentially rebel. Indicators for political 'grievances', e.g., the political discrimination of specific groups, were not found to play a significant role.

While these macro level studies certainly have their merits and can claim credit for initiating the academic debate, they reach their limits when it comes to more differentiated questions, such as: 'What drives rebel organisations into violence?', 'Which groups are most severely affected by conflict?' or 'Which policy approaches work best for which part of the conflict-affected population?' Furthermore, empirically capturing 'war' is inherently difficult as one always has to rely on some type of ad hoc threshold of violence from which onwards rebellions or violent crime are to be considered as war (Sambanis 2004). Making causal inferences is another challenge in cross-country comparisons, although authors have found interesting instrumental variables

\footnotetext{
${ }^{1}$ For a detailed literature review of theoretical and empirical articles on the causes and legacies of civil war, see Blattman and Miguel (2010).
} 
when assessing the role of income in driving conflict (for example rainfall shocks in Miguel et al. (2004) or peaks in commodity prices in Besley and Persson (2009)). Still, the issue remains that the mere income - conflict nexus does not shed light on facets between wars.

Thus, especially with increasing data availability and quality at the household and regional level as well as the use of geo-coded information on violent events (for example Päivi et al. 2007 and Raleigh et al. 2010), micro level analyses offer a promising way forward in the conflict literature. They allow for specific wars' particularities to be accounted for and offer the possibility to detect natural experiments or other clean identification strategies. ${ }^{2}$ Although these works also discuss the reasons why individuals join groups and how these overcome collective action issues of mobilisation - again, economic motivations are often found to be dominant (Justino 2009) a large share of the empirical articles focusses on the consequences of violence for households. These can be direct (e.g., through changes in household composition because of deaths, changes in their economic situation following physical destruction, or through forced displacement) or indirect (i.e., at the community or national level represented by access to public goods and services) (Justino 2008). Among many other impacts, the literature suggests that civil war increases poverty and can have a detrimental effect on children's nutrition and, consequently, their likelihood to die (Verwimp 2012, Akresh et al. 2011). But violent conflict has also been found to shape people's values and their social behaviour, thus influencing the potential for the development of markets and democracies in the long run. Depending on the context, both strengthened and weakened social bonds have been documented (inter alia Blattman 2009, Cassar et al. 2013, Gilligan et al. 2014, and Rohner et al. 2013). What is more, the structure of the economy and the society of a country is often modified, e.g., regarding gender roles and female labour force participation (Menon and van der Meulen Rodgers 2013).

This dissertation contributes to this developing, quantitative literature on the causes and consequences of violent political behaviour at the micro level. The three chapters summarised below cover three different topics, namely the effect of regional oil resources on the violent behaviour of political groups, the effect of refugees on the host population as well as the long-term impact of war on female labour force participation. In each of these chapters, the focus lies on the sub-national level in order to draw a nuanced picture of the contexts studied, such as the specific characteristics that make a group rebel, the occupations that benefit and suffer most from refugee presence or which cohorts of women were drawn into the labour market by the Vietnam War. Each chapter finishes with individual policy recommendations and suggestions for further research in the field. In the following paragraphs, every chapter is summarised.

\footnotetext{
${ }^{2}$ For a literature review focussing especially on the micro level, see Justino (2009).
} 


\subsection{Synopsis of Chapter 1: Weapon of Choice}

The discovery of natural resources should allow a country to use the revenues for the social and economic good of its population. However, the civil war literature has widely found the presence of a 'resource curse', i.e., the effect of resources weakening institutions and possibly causing conflict (e.g., Fearon and Laitin 2003, Collier et al. 2009). ${ }^{3}$ Notably, in a study analysing 13 cases in detail with the aim of disentangling the causal channels, Ross (2004) stresses the importance of the distribution of extractable resources across the territory of a country. In contrast, works on terrorism have largely neglected the effect of fossil fuels. This is surprising as it can be expected that channels at work in the oil - conflict nexus could also apply to terrorist activities, for example economic or political discrimination, suppression of some parts of the population or negative externalities of the extraction process (Hunziker and Cederman 2012 and Karl 2007).

Taking up these motivations, this chapter applies the 'rational actor' theory to the strategic behaviour of groups, expecting higher returns or lower risks to make violence relatively more likely than peace. We use political group level data for the Middle East and North Africa, covering the years 1980 to 2004, and combine them with geo-coded information on the occurrence of oil and gas reserves on these groups' territories. Exploiting the panel-structure of the MAROB dataset (Minorities at Risk Organizational Behavior, Asal et al. 2008), we run multinomial logit models in order to distinguish determinants of peaceful, terrorist and large-scale violent behaviour of ethno-political groups. We find that the existence of mineral resources does not affect the choice to resort to terrorist means, while insurgencies become significantly more likely where a group has the prospect of controlling revenues from oil extraction. This effect can be mitigated by political participation at the central state level, thus increasing the access to revenues by peaceful means. Contrary, proven desire for autonomy or the support by a foreign state make (secessionist) conflicts more probable.

The results of the first chapter lead us to conclude, first, that regional distribution of resources and group characteristics are indeed crucial determinants of violent behaviour. This information is lost in cross-country analyses. Furthermore, terrorism appears to be driven more by political factors and insurgency by economic ones (a finding also put forward by Sambanis (2008)). In the vocabulary of the civil war literature, 'greed' dominates 'grievances' also at the micro level of violent conflicts.

\footnotetext{
${ }^{3}$ Here, 'natural resources' is used synonymously with 'fossil fuels' or 'oil'. Diamonds or renewable natural resources such as coca are not considered.
} 


\subsection{Synopsis of Chapter 2: Their Suffering, Our Burden? How Congolese Refugees Affect the Ugandan Population}

Refugee situations around the world become increasingly protracted, meaning that the displaced cannot return to their home countries for an average of 17 years (Jacobsen 2002). Despite providing important insights for policy makers designing refugee acts accounting for a long-term perspective, the quantitative empirical literature on the consequences of hosting refugees for the local population is scarce. Uganda represents a particularly valuable case to study as it has been hosting refugees - mainly from Rwanda, Burundi and most recently from the Democratic Republic of the Congo - for decades and follows a unique policy approach: Rather than confining the displaced to camps and prohibiting them from moving outside or taking up work, the Ugandan government aims at their 'local integration', both in economic and social terms (Fielden 2008). This means that refugees enjoy freedom of movement and of working, inducing frequent interaction with the host population in the labour and goods markets. Their public services are combined with the ones for the Ugandans in order to avoid duplication of structures (Dryden-Peterson and Hovil 2004). In addition to the long-term policies, new influxes pose a challenge requiring emergency assistance.

The second chapter carries out an evaluation of the Ugandan refugee legislation regarding its aim to increase economic activity around refugee settlements and to improve access to public infrastructure for the national population. Furthermore, the perceptions of the host population are taken into account. I use three waves of two different household surveys over the period 2002 to 2010 in order to compare areas hosting refugees with ones that do not in a difference-in-differences framework. In doing so, the long-term presence of refugees is differentiated from additional sudden shocks. I find that Ugandans living close to refugee settlements are better off in terms of consumption and access to public services, especially primary schooling. Possible channels include enhanced market size, foreign aid spilling over to the nationals, and improved infrastructure such as roads (see, e.g., Maystadt and Verwimp 2014). However, these improvements in objective measures are not reflected in subjective indicators. Those Ugandans located in refugee-hosting areas perceive themselves to be worse off than their fellow nationals and are alienated from their central state.

I conclude that the Ugandan policy approach is a promising one as it offers the refugees a long-run perspective independent from aid while at the same time improving the livelihoods of the local population. Yet, the process can only be fully successful with the support of the Ugandan people so that information and inclusion campaigns should be intensified. Meetings between the refugees and the hosts could also be a solution to reduce prejudices. 


\subsection{Synopsis of Chapter 3: Missing Men: Differential Effects of War and Socialism on Female Labour Force Participation in Vietnam}

The perception of what women should and should not be doing in a society is a rather inflexible concept, in many cases confining them to the role of housewife and mother (e.g., Gaddis and Klasen 2014). Yet, violent conflict through reduced household income and a lack of labour supply induces significant powers pushing and pulling women into new positions as men are absent. With the support of a theoretical model as well as anecdotal evidence, we hypothesise that these exogenous dynamics have the potential to 'fast forward' cultural change as social learning about gender stereotypes is initiated and the stigma attached to working women is muted. Another important factor regarding social views is the political context, namely the dominant political ideology. Particularly socialist systems have the reputation of fostering female economic empowerment (e.g., Klasen 1994).

Both these dynamics, war and socialism, have been at play in $20^{\text {th }}$ century Vietnam. Quantifying and comparing their impact renders important policy implications and sheds light on the question of the permanence of changes during crises. Using three waves of censuses $(1989,1999$, and 2009), we implement probit models estimating the determinants of a woman's choice to enter the labour market. We proxy the effect of the conflict with the share of female population shortly after the war and the effect of socialism with the length of pre-economic reform socialist rule in the Northern part of the country. In order to differentiate the effects of war for women directly affected by it from women only reaching working age after its end, we also carry out a cohort analysis, interacting our indicator for 'missing men' with binary variables for different birth cohorts. We find a significant and positive impact of the share of female population on the probability to work for women of working age during the Vietnam War. For younger generations the effect is still positive but smaller and less robust. In contrast, living in the North and thus having been exposed to socialism for a longer period of time substantially increases the likelihood of a woman working.

We conclude that, although women indeed increasingly entered the workforce in the course of the Vietnam War, this exogenous shock only produced a muted long-term cultural change in perceptions regarding gender roles. Yet, policies supporting working women, such as child care and parental leave as introduced under the socialist Northern Vietnamese regime do have an enhancing effect on female labour force participation. Combining these two findings, well-designed policies after a conflict have the ability to stabilise potentially desirable results of dire straits, such as more working women, thus preventing a fall-back into the pre-war status quo. 


\title{
2 Weapon of Choice
}

\begin{abstract}
We investigate the effect of natural resources on whether ethno-political groups choose to pursue their goals with peaceful as compared to violent means, distinguishing terrorism from insurgencies. We hypothesise that whether or not the extraction of fossil fuels sparks violence depends both on the group's characteristics and the state's behaviour. We use data from the Minorities at Risk Organizational Behavior (MAROB) project, covering 118 organisations in 13 countries of the Middle East and North Africa over the 1980-2004 period. Our multinomial logit models combine group- and country-specific information and show that ethno-political groups are more likely to resort to rebellion rather than using peaceful means or becoming terrorists when representing regions rich in oil. This effect is enhanced for groups already enjoying regional autonomy or being supported by a foreign state but can be mitigated by power sharing arrangements.
\end{abstract}

\subsection{Introduction}

The discovery and exploration of oil reserves gives rise to high hopes among the populations of these resource-rich countries. Resource-abundance can however also turn into a threat to stability and peace, particularly in poor and badly governed countries. While this aspect of the so-called resource-curse is widely discussed in the context of civil wars (e.g., Fearon and Laitin 2003; Collier and Hoeffler 2004), it has largely been neglected when analysing the causes of terrorism. ${ }^{4}$ This neglect is surprising. In a large number of countries, natural resource abundance has disadvantaged the local population, leading to high regional unemployment and mass immigration (Karl 2007). It thus seems straightforward that marginalised populations in areas with a wealth of natural resources might resort to terrorism in order to express their grievances. This problem plays a particularly important role in the Middle East and North Africa (MENA) region, which has a large number of oil-rich, fragile states.

Consider Iraq. Political groups such as the Kurdistan Democratic Party or the Patriotic Union of Kurdistan, which represent the Kurdish minority in the North of the country, first fought for more autonomy, then for their own state. During the course of this fighting, they have resorted to violent means, both at a terrorist scale and at a larger battle-sized scale. While the public discourse of the movement focuses on the discrimination of this largest people without their own territory, petroleum reserves are likely to be another important driver of their unrest. Despite obtaining significant regional autonomy in 1991, the situation has remained tense, with oil revenues being a main cause of conflict both among Kurds (Wimmer 2002) and between the

This is joint work with Axel Dreher.

We thank Dominik Noe for participating in developing the idea and constructing the database for this paper. We thank Todd Sandler and other participants of the Terrorism and Policy Conference 2014 for helpful comments and Jamie Parsons for proofreading.

${ }^{4}$ For a detailed definition of the concepts of civil war and terrorism, please see section 2.3 . 
Kurds and the national government (Chulov 2009).

In this chapter, we investigate whether and to what extent the availability of oil determines whether ethno-political organisations choose to pursue their aims with peaceful means, resort to terrorism, or start insurgencies, thus closing an important gap in the literature. Our focus is on political organisations claiming to represent the interest of specific ethnic populations before their own state, i.e., we look at activities within their own country, at the sub-national level. ${ }^{5}$ To the extent that resorting to violence is a rational step taken by the respective organisation, the type of violence applied is a strategic choice, depending on the organisation's characteristics, the context, and the reaction of the state to its actions. Applying the rational actor approach, we theorise that groups will weigh risks and benefits of their political actions based on the support they enjoy, their aims, and the strength of the state they face. Factors that we will include in our analysis are, inter alia, discrimination, access to power, and support by a foreign state.

While there are some studies on the country level either predominantly focusing on greed or on the relative importance of greed and grievances (see, inter alia, Collier and Hoeffler 2004, Collier et al. 2009 and Regan and Norton 2005) as well as a more recent article by Hunziker and Cederman (2012) analysing the behaviour of ethnic groups, we look at political organisations, thus adding an important perspective to the literature. As highlighted in Asal and Wilkenfeld (2013), the actions of an organisation claiming to act on behalf of an ethnic group may not actually be representative of that group. At the same time, investigating ethnic groups in their entirety might hide important differences among the various organisations representing each group.

We test our hypotheses using data from the Minorities at Risk Organizational Behavior (MAROB) dataset, as we explain in more detail in section 2.3. In the same section we also explain how our multinomial logit panel models combine organisation- and country-specific information to test the determinants of an organisation's choice between pursuing their goals with peaceful means, taking up arms for small-scale terrorist activities, or for a larger scale rebellion.

We present our results in section 2.4. They show that insurgencies are more likely with larger resource extraction, both with respect to peace and to terrorism. This leads us to conclude that economic considerations (or greed) are the main channel through which natural resources affect large-scale violence. This reasoning is underlined by two further results linking the desire to control a territory comprising oil reserves with violence: Both support by foreign states as well as regional autonomy (and thus a demonstrated will for at least some independence) enhance

\footnotetext{
${ }^{5}$ As Denny and Walter (2014) point out, the bulk of civil wars are initiated by an ethnic group, frequently as a consequence of grievances along ethnic lines.
} 
the escalating impact of oil. The choice to engage in terrorist activities however is not affected by resource availability within a group's territory. While terrorism seems to be driven more by political factors, grievances generated by the extraction of oil are not sufficiently strong to induce terrorist activities among the groups in our sample. The final section 2.5 concludes the chapter.

\subsection{Theory}

As Hunziker and Cederman (2012) point out, the civil war literature widely accepts the existence of a link between petroleum and intra-state conflict. Fearon and Laitin (2003), Humphreys (2005) and De Soysa and Neumayer (2007), among many others, find that countries rich in oil and gas have a higher risk of civil war. This is attributed to a number of factors that can broadly be classified to represent, first, greed or opportunity and, second, grievances. The greed-based hypothesis postulates that resources directly lead to rebellions or coups because controlling an area or state rich in resources is comparably more valuable than one without them. The presence of natural resources has been shown to weaken institutions, as politicians have no incentive to develop them when they do not have to rely on a broad tax base (e.g., Fearon and Laitin 2003). Furthermore, resource abundance allows rebel groups easy access to finance, making revolutions more feasible (Collier et al. 2009).

However, the grievance-channel to violent behaviour should not be neglected, and be it as an ideological factor of mobilisation. Indeed, as De Soysa and Binningsbø (2009) show, natural resource abundance leads to the repression of large parts of the population. Hunziker and Cederman (2012) show that violent reactions of ethnic groups become likely when members of the group feel themselves deprived of their fair share of gains from natural resources and when these resources incur negative externalities on them. Their examples of externalities include the reorganisation of land rights, pollution, disruptions of the labour market due to shifts in demand away from unskilled workers, large-scale in-migration, urbanisation, and rapid centralisation of state powers. They thus find the role of grievances to be of equal importance to that of greed in explaining civil war, rather than just having residual explanatory power. ${ }^{6}$ Karl (2007) points out that the oil industry is highly capital-intensive and therefore creates few jobs, in particular for unskilled labour, and is dominated by foreigners, thereby marginalising domestic businesses. She also stresses the absence of a significant multiplier effect of oil wealth, limited opportunities for technology diffusion, and consequently low living standards for large parts of the population in areas rich in oil. Among the unwelcome effects of oil Karl (2007) stresses increased prostitution, prevalence of HIV/AIDS, environmental damage, increases in the costs of living, and food price instability.

\footnotetext{
${ }^{6}$ Also see Denny and Walter (2014).
} 
Arguably, such negative effects will be mitigated by participatory political institutions. As shown in Hunziker and Cederman (2012), the risk of civil war as a consequence of resource abundance is linked only to those groups that are excluded from the central government as such groups perceive the interference by the central power, the extraction, and the resulting externalities to be illegitimate.

In a study on 13 cases, Ross (2004) tests a number of potential causal channels for the resourceconflict relationship. While he finds neither greed nor grievances to matter for non-separatist civil wars, he stresses the importance of the geographical distribution of oil across the country. Separatist motives are likely to come into play in cases of grievances over the distribution of benefits from resource extraction or based on the incentive to control these revenues. He also shows pre-emptive repression of groups by the own state out of fear to lose control over resources as well as interventions by foreign states to spark civil wars.

In contrast to the literature on larger scale civil unrest, natural resources hardly feature in the literature on what determines terrorism. ${ }^{7}$ Exceptions to this are Tavares (2004), Bravo and Dias (2006), and Sambanis (2008). Tavares (2004) includes primary goods exports as a share of GDP as a measure of resource abundance in his analysis of what determines terrorism, but does not provide a specific theory as to why resources should matter. He does not find resource abundance to be associated with more terror - in fact, he finds that resources reduce terror. Sambanis (2008) includes a binary variable indicating dependence on oil exports as a control variable in his cross-sectional analysis of what determines the existence of terrorism, and finds it not to be significant at conventional levels. Bravo and Dias (2006) test whether countries of geo-strategic importance are more prone to become victims of terror, and include the existence of large energy and mineral reserves among their variables of strategic importance. Their results show that top suppliers of minerals (but not of energy) experience more attacks, in a cross-section of 60 countries. Based on these papers, Gassebner and Luechinger (2011) include the share of a country's total exports made up by primary goods in their large-scale robustness analysis of what determines terror, exploiting varying definitions and sources of terrorism. Across their models, they do not find a robust relationship between the share of primary goods among a country's exports and the number of terrorist attacks against its citizens.

Arguably, the presence of natural resources is important in determining the extent of terrorism as well as insurgencies. The externalities of mineral resource extraction described above

\footnotetext{
${ }^{7}$ We refer here to oil, gas, diamonds and other non-renewable valuables rather than renewable resources such as wood or narcotics. There is a substantial literature on the relation between narcotics and terrorism, in particular regarding the financing of terrorist activity in Colombia (one example is Leech 2004).
} 
all compound into substantial grievances, potentially also leading representatives of repressed minorities to resort to terrorist activities. ${ }^{8}$ The neglect of natural resources in the literature on terrorism is thus surprising.

So far, our discussion concerned the choice of violence over peaceful means, but we have had no hypotheses regarding the likelihood of resorting to terrorism over insurgency or vice versa. Sambanis (2008) stresses that terrorism and civil wars are distinct strategic choices, with civil wars being driven more by economic factors and terrorist activities rather by political aspects. The logic of opportunity cost established in the context of civil war would then not fit terrorists' considerations. Regan and Norton (2005) differentiate between the importance of grievances as the backbone of a movement and of resources as the means of paying out selective benefits to group members. They find that, overall, similar factors are related to protest, rebellion, and civil war (namely, income and distributional issues, repressive policies of the state, and access to exploitable resources) but that the reaction of the state determines whether violence escalates, where repression is more effective at lower than at higher levels of violence. ${ }^{9}$

A small and recent literature analyses groups that apply terrorism during civil war (but not the distinct choice between them), finding that democracies are more vulnerable to civilian casualties and thus to terrorism, while groups depending on mass mobilisation would not attack civilians (Stanton 2013). Additionally, terrorism appears to benefit the group's survival, but not to be effective in reaching their political goals (Fortna 2014). Findley and Young (2012) describe how the five strategies of terrorism - provocation, attrition, intimidation, outbidding, and spoiling play different roles before, during, and after a conflict.

The approach of looking at groups rather than at countries is valuable both from a theoretical and from an empirical point of view. Conceptually, the greed versus grievances debate seems too broad and simplistic (Keen 2008). Finer degrees of motivation and strategic policy choices are likely to play a role, which can only be identified by looking at organisations. One possibility to theoretically capture these strategic considerations is to apply the rational actors' perspective and to assume that a group's ability for collective violence depends on its members' expected costs and benefits taking into account the socio-economic and political context (Conteh-Morgan 2003). The group does not operate in a vacuum but is affected by its surroundings, especially the state against which it rebels and which reacts to this threat. The institutional environment

\footnotetext{
${ }^{8}$ One might argue that natural resources would allow governments to buy consent or repress opposition, thereby reducing terror rather than increasing it (Karl 2007; De Soysa and Binningsb $\varnothing$ 2009). However, such effects should be absorbed by control variables such as GDP per capita and democratic participation. We therefore hypothesise terror to increase as a consequence of natural resource abundance.

${ }^{9}$ Besley and Persson (2011) develop a similar logic.
} 
influences the ability of opposing groups to mobilise, their perceived chances of success and the political measures at their disposal (Muller and Seligson 1987). Noticeably, collective action turns violent when those protesting against a certain perceived grievance do not have access to institutions that peacefully mediate them (Tarrow 1998). The power (a-)symmetry between the group and the state as well as the level of public support determine the degree of mobilisation and the type of violence (Sambanis 2008).

In the context discussed here, a group's strategic 'weapon of choice' will depend on the balancing of costs and benefits of reaching the political aim most efficiently. The extent of mobilisation clearly smaller for terrorist activities than for insurgencies as the former can also be actions of individuals - then depends on both the need or the desired political outcome as well as on the ability, i.e., the strength of the state and the number of people willing to join the movement.

Based on the theoretical considerations and the evidence described in this chapter, our empirical analysis is built along the following hypotheses: First, the mere existence of fossil fuels in a region is likely to lead to disturbances which can cause both terrorism and insurgency, while at the same time revenues can be used to pay selective benefits (see, e.g., Regan and Norton 2005). We thus expect an increasing effect of oil revenues on both forms of violence relative to peace. Second, this effect on insurgencies should be mitigated by mediating political institutions, i.e., with increased citizen participation in the wealth created by the resources and in deciding about how to exploit them (Hunziker and Cederman 2012). In line with Dreher and Fischer (2012), we expect participation in power to also reduce the extent of terrorism. Closely related, political discrimination should enhance violence linked to resources (Dreher and Fischer 2012). Following Sambanis (2008), we consider terrorism to be driven more by political reasons and insurgencies by economic ones, thus expecting the effect of discrimination to be stronger for terrorist activities. We interact our oil measure with indicators for participation in the central government and for political discrimination to test these hypotheses. We thereby expect a violence-decreasing impact for the groups being part of the central government and an escalating effect of discrimination in political opportunities. In contrast, where separatist ambitions exist and a state of autonomy has already been reached, oil revenues can be a motivation to strive for complete secession which will usually only be possible using violence as the central state is unlikely to give up territory (Ross 2004). An example for this process are the Kurds in Iraq as described in this chapter's introduction. Thus, third, we interact our oil measure with an indicator for regional autonomy and expect an escalating effect only for insurgencies. Fourth, as Karl (2007) points out, oil-induced income inequality is likely to be perceived as more severe compared to similar levels of inequality due to other reasons because the income generating 
process is perceived to be unfair. We therefore also interact our measure of resource abundance with economic discrimination and just as for political discrimination expect a stronger impact on terrorist activities than on civil wars. Fifth, we expect the strength of the group to play a key role. The stronger the state relative to dissenting groups, the higher the probability that such groups will turn to terrorism rather than other forms of violence. ${ }^{10}$ Or termed the other way around: If a group feels strong enough vis-à-vis the state, it will dare to take up arms in a more coordinated fashion (Ross 2004, Regan and Norton 2005, and Sambanis 2008). We will test this using the variable of whether a group is supported by a foreign state as a proxy for the strength of an organisation as 'an available source of support external to the arena of conflict can empower organisations to engage in contentious politics in a way inaccessible to those without similar sources' (Asal et al. 2013, p. 309f.).

\subsection{Method and Data}

Our approach follows a number of recent papers focusing on violent organisations, all relying on multinomial logit regressions. Among them, Gaibulloev and Sandler (2014) examine what determines how terrorist groups cease to exist. Asal et al. (2015) focus on an organisation's choice to target civilians. Carter (2012) investigates the impact of state support on group survival, while Meierrieks and Krieger (2014) model the choice between terrorism and civil war, as we do here. ${ }^{11}$ We follow this literature and estimate our model as a multinomial logit. This allows us to determine differential impacts of the variables of interest on the strategic choice of the observed political organisations. This assumes that the process from peace to terrorism to insurgency is not continuous, i.e., it is not a process of (de-)escalation, but rather represents separate decisions. However, even if the process were ordered, the multinomial specification would still be important for us to be able to estimate separate coefficients for the explanatory variables for each possible outcome. When organisations engage in terror and larger scale insurgencies at the same time we code them as insurgencies, as our method of estimation requires the groups to be exclusive. ${ }^{12}$

We implement our specification as a multi-level model, which allows us to exploit the panel

\footnotetext{
${ }^{10}$ According to Carter (2014)'s game-theoretical analysis, states that are better able to fight groups with territorial objectives attract more terrorism.

${ }^{11}$ Meierrieks and Krieger (2014) compare the determinants of Islamist terrorism and civil wars that involve Islamist groups for 155 countries between 1968 and 2006. They find that the onset of Islamist conflict is associated with the discrimination of Islamic minorities, military dependence from the U.S. and a large Muslim population. Large governments and external cultural influences, in contrast, matter for the onset of Islamist terrorism.

${ }^{12}$ Of the 525 observations (group-years) coded as being involved in an insurgency by us, 30 percent also apply terrorism. Our results do not change when we omit those observations that are coded for more than one form of violence. While our main models are unable to distinguish the coexistence of the two forms of violence as a fourth category from the other categories, results are unchanged in a multinomial logit model with year fixed effects and standard errors clustered at the organisation level. Insurgency is still significantly determined by oil reserves on a group's territory but this relationship is neither significant for terrorism nor for the overlapping category.
} 
structure of our dataset and thus variation for the same group over time rather than across organisations. This is a novelty with regards to the other studies using multinomial logit models introduced above. We assume the three choices that every organisation can take in each year (peace, terrorism, and insurgency) to be nested in organisations, as an organisation's decisions in different years will not be independent from each other. We include random intercepts for each organisation, thereby splitting the residual into one part that is identical for all decisions of the same group and one part that is specific to the choice of that organisation in a particular year. We assume that the organisations' 'choice of weapon' in each year is conditionally independent given the organisation random effect and the explanatory variables. ${ }^{13}$ Our reduced-form empirical model is at the organisation-year level:

$$
\text { Weapon }_{i, t}=\alpha+\beta \text { Resources }_{i, t-1}+\gamma X_{i, t-1}+\delta \text { Resources }_{i, t-1} * X_{i, t-1}+\zeta Z_{i, t-1}+\epsilon_{i, t},
$$

where Weapon reflects organisation $i$ 's weapon of choice in year $t$ and Resources is our indicator of natural resource abundance in the preceding year. We expect $\beta>0 . X$ represents the variables we interact with oil production to test our hypotheses: (i) two indicators for a group's possibilities to participate in political decision making processes, namely political discrimination and whether the ethnic group shares central power with others; (ii) an indicator for regional autonomy of the ethnic group; (iii) an indicator for the group being economically discriminated against; and (iv) whether a group was supported by a foreign state. We expect $\delta>0$ in all cases but for power sharing where it should be $\delta<0$. $Z$ contains our control variables (at the country and group level) and $\epsilon$ is the error term, which is clustered at the organisation level. All our independent variables are lagged by one year in order to minimise bias due to reverse causality.

Our main variables are taken from the Minorities at Risk Organizational Behavior (MAROB) dataset (Asal et al. 2008). The dataset contains an unbalanced panel of organisation level information on 118 political organisations claiming to represent the interests of 22 ethnic groups in 13 countries and territories of the Middle East and North Africa, over the 1980-2004 period. ${ }^{14}$ Our dependent variable measures whether an organisation is peaceful in a given year (then it takes the value zero), whether it carries out any terrorist activity (represented by a value of one), or whether it is involved in a larger scale insurgency (then it is equal to two). ${ }^{15}$ Distinguishing

\footnotetext{
${ }^{13}$ We implement the model using the gllamm package in Stata 13.0 (Rabe-Hesketh et al. 2004). A possible third stage would be the country-level. However, due to the small number of countries in our sample the resulting model is fragile when estimating a three-level model. Including dummies for each country is also not an option as some countries do not have any oil (and thus no variation in our variable of interest), and we would lose the observations for six out of the 13 countries in the sample. We therefore do not use these models.

${ }^{14}$ The countries and territories included in the sample are Algeria, Bahrain, Cyprus, Iran, Iraq, Israel, Jordan, Lebanon, Morocco, Saudi Arabia, Syria, Turkey, West Bank and Gaza.

${ }^{15}$ Our 'peace' category comprises both inaction and non-violent political action such as protests etc. As we are mainly interested in severe attacks on the state we do not specifically address issues raised in a fashion not challenging the state's monopoly of violence.
} 
the two forms of violence is a key challenge to our econometric analysis. We will rely on a combination of action-based (the level of violence) and actor-based (the group's attributes) approaches (Asal et al. 2012). According to Mickolus et al. (2004) 'terrorism is the use or threat of use, of anxiety inducing extranormal violence for political purposes by any individual or group, whether acting for or in opposition to established government authority, when such action is intended to influence the attitudes and behaviour of a target group wider than the immediate victims. ${ }^{16}$ Criteria for the inclusion of a group in the MAROB database include that they must not be created by the government and that they have to be political in their goals and activities. Following a large number of previous studies, the definition for terrorism applied here is a narrow one, comprising violent attacks on civilians only (including non-security state personnel such as civil service personnel and government representatives that are not police, military, etc.), but excluding those on state institutions and the military, which are conceptually different and often termed as guerilla activities (see inter alia Kydd and Walter 2006; Abrahms 2012; Fortna 2014). ${ }^{17}$ Specifically, any group that attacked civilians directly on a low scale or forcefully secured their support is deemed to be a terrorist organisation. ${ }^{18}$ Large-scale violent events include those targeting security personnel and state institutions as well as those attacks that attempt to seize control over a town, guerilla activity, and civil wars fought by rebel military units with base areas. Violence arising from groups with control over a specific area with some degree of governance structure is also included in this category. ${ }^{19}$

Asal et al. (2008)'s data have two main advantages over alternative datasets. First, they are available at the organisation- rather than the ethnicity or country level. Compared to data at

\footnotetext{
${ }^{16}$ See Enders and Sandler (2012) for a detailed discussion.

${ }^{17}$ Specifically, we code our dependent variable as terrorism when any of MAROB's variables orgst6 or orgst'7 are greater than zero, or domorgviolence equals one, four, or five. Orgst6 is a three-scale ordinal variable where values larger than zero indicate that a group forcefully secures financial, material, or personnel support from the local population. Orgst7 is a three-scale ordinal variable, where values greater than zero imply that a group attacks civilians, including non-security state personnel. Domorgviolence is a six-scale ordinal variable where one indicates that an 'organisation is using violence as occasional strategy but is not specifically targeting persons,' four implies that a group 'is occasionally targeting civilians,' and five shows that it is 'targeting civilians regularly.'

${ }^{18}$ The MAROB dataset defines terrorism in the narrow manner that we do, and this definition is similar to the criteria for inclusion in the most recent version of the Global Terrorism Database (GTD). Among the large number of definitions of terrorism, there are also broader ones encompassing those groups that mainly or exclusively attack state institutions. As our aim is to distinguish terror from broader insurgencies and to identify differences in their respective determinants, we choose this specific cutoff, while in reality the borders can be blurred. When we rely on the broader definition instead, our results regarding the determinants of violent behaviour with peace as a base category remain very similar, while we hardly find differences between the two forms of violence.

${ }^{19}$ Specifically, we code our dependent variable as insurgency when MAROB's variable domorgviolence equals two or three, orgreb is greater than two, or orgst8 or orgst9 are greater than zero. For domorgviolence this implies that an organisation 'is using violence regularly as a strategy but is targeting security personnel.' Orgreb is an eightscale ordinal variable where values greater than two imply that an organisation is involved in 'local rebellion,' 'small-scale guerilla activity,' 'intermediate guerilla activity,' 'large-scale guerilla activity,' or 'civil war.' Orgst8 is a three-scale ordinal variable with values greater than zero implying 'small-scale' and 'intermediate guerilla activity'; orgst9 is a three-scale ordinal variable where values greater than zero indicate that a group 'controls movement into/ out of a territory' or 'sets up government structures.'
} 
the country level, this allows using geo-coded data on natural resources to test whether resources in a certain region affect violence related to the same region. More broadly, our data allow the investigation of more differentiated reasons for violence. Compared to the ethnic group level, organisation level data allow exploiting variation in individual organisations' 'choice of weapons' that represent the same ethnicity. Rather than attributing violence to ethnicities as a whole, characteristics of groups from the same ethnicity can be distinguished (Asal and Wilkenfeld 2013). Second, the dataset includes peaceful as well as violent groups. This is contrary to most previous organisational level studies that include organisations only once they become violent (Stanton 2013; Fortna 2014) and are therefore unable to examine the determinants of whether organisations choose to be violent per se (rather than the amount of violence). However, the data have a number of drawbacks as well that we would like to stress from the outset. The most important drawback is the limited regional coverage and the resulting small number of independent observations we can exploit for our regressions. The MENA region is different from other areas in a number of ways, so that we are careful in not generalising our results to other regions of the world. What is more, while Asal et al. (2008) follow clear guidelines on how to code organisations' actions, the boundaries between terrorism and insurgencies in particular are sometimes blurred (Sambanis 2008), and the resulting data are noisy. We have no reason, however, to expect a systematic bias in testing our hypotheses and make this distinction as clear as possible by applying the strict definition described above.

We rely on two indicators for natural resource abundance, coded at the regional level. Our main resource indicator follows Hunziker and Cederman (2012) who use data from the 'Giant Oil and Gas Fields of the World' database (Horn 2010), which includes geo-coded information on the location and size of petroleum occurrence in million barrels of oil equivalents across the world (for fields containing at least 500 million barrels oil or gas equivalents). The data allow us to code the share of a state's oil reserves that is situated on a specific ethnic group's territory. We follow Hunziker and Cederman in using the annual value of a country's oil production (taken from Ross 2013) to estimate the return to oil production on a group's territory in a given year

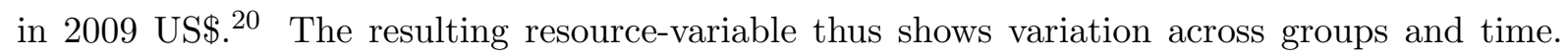
Given that the variable is highly skewed, we use it in logs. ${ }^{21}$

Our second indicator of resource abundance is a binary indicator based on the geo-coded location

\footnotetext{
${ }^{20}$ For a detailed discussion of the merits and drawbacks of this measure see Hunziker and Cederman (2012).

${ }^{21}$ In cases without any fossil fuels on the territory of a group, we apply a Box-Cox type transformation, specifically, we add one to the oil value. This approach is reasonable as the next largest non-zero value is $1,827,721$ so that one is sufficiently small.
} 
of oil and gas fields in PRIO's Petroleum dataset v. 1.2 (Päivi et al. 2007). ${ }^{22}$ Compared to the data in Horn (2010) it has the advantage of also including rather small fields. However, these data do not measure the degree of resource abundance. What is more, they hardly vary within groups in the same country and do not vary at all within the same country over time.

We use a number of variables to control for observed heterogeneity at the group and country level. At the group level, and also taken from the MAROB database, we control for the goals of a group. Specifically, we include indicator variables for organisations that aim to eliminate political, economic, or cultural discrimination, groups that aim for autonomy or independence, and groups that want to establish an Islamic state. ${ }^{23}$ Asal et al. (2008) coded these variables based on the expressed aims and motivations of the groups as reported in newspapers and other sources. We expect fighting for autonomy or independence, or an Islamic state, to lead groups to taking up arms at a larger scale as these are goals that states do not usually give in to, considering how drastically this would cut into their authority and integrity. Organisations with 'other' goals are the omitted category.

We control for whether organisations receive financial, political, humanitarian or military support from foreign states, as this is likely to fuel violence, for example through improved logistical support or finances. We control for negotiations between the state government and the political organisation, as members of the group that do not wish to reach an agreement with the state or that expect larger concessions when showing strength could opt for increased violence. In addition, we include whether or not the government uses violence against an organisation, that is, if the organisation is considered legal or if it faces lethal violence by the state. ${ }^{24}$ We also add a variable indicating if a group provided social services as this requires a certain degree of organisation as well as financial means and thus strength.

At the country level, we rely on a number of standard control variables from the terrorism and civil war literature. Due to our very small sample size regarding countries, however, we will not put a huge weight on their estimated coefficients, as their standard errors are likely to be biased. We control for whether the country is a democracy, relying on indicators from Freedom House (2014) for the average of the civil liberties and political rights, ranging between

\footnotetext{
${ }^{22}$ Other, more easily lootable resources such as diamonds or narcotics might also be relevant for our hypothesis. However, such resources are hardly relevant in the region we consider here - the Middle East and North Africa. ${ }^{23}$ The goals of a group might reflect the degree of grievances it experiences and might thus close an important transmission channel for how resource abundance affects terrorism and insurgencies. When we exclude these variables, however, our results are very similar.

${ }^{24}$ This is a binary indicator that equals one when Asal et al. (2008)'s three-scale ordinal variable stateviolence is larger than one, indicating that a state is using 'periodic lethal violence' or 'consistent lethal violence against the organisation.'
} 
one and seven, with higher values indicating less freedom. ${ }^{25}$ We also include a country's logged GDP per capita (in purchasing power parities (PPP) and constant 2005 international Dollars) to proxy for its level of development. As Sambanis (2008) points out, the negative correlation between per capita GDP and civil war is widely accepted. GDP per capita however is not a robust determinant of terrorism (Abadie 2005, Sambanis 2008) - the evidence in Gassebner and Luechinger (2011) is mixed. ${ }^{26}$

We control for ethno-linguistic fractionalisation because of the assumption that a higher degree of fractionalisation leads to a higher potential for conflict. However, the empirical evidence regarding the effects of fractionalisation is mixed (see Blattman and Miguel 2010). We take these data from Yeoh (2012), measured as the probability that a randomly selected pair of individuals in a society will belong to different groups, ranging from 0 to 1, i.e., from complete homogeneity to every individual belonging to a separate group.

In line with the previous literature we expect greater levels of repression in countries with larger populations, as the risk of conflict is larger there (De Soysa and Binningsbø 2009). Gassebner and Luechinger (2011) find population to be among the few variables that robustly increase terrorism. Collier and Hoeffler (2004) and Collier et al. (2009) find the risk of civil war to increase with population. Following Hunziker and Cederman (2012) we also control for the logged value of oil produced at the national level, which could be related to facets of the resource curse relevant at the country rather than the group level. We show the sources of all variables and their descriptive statistics in Appendix A1, while Appendix A2 reports the exact definitions of all variables.

\subsection{Results}

Table 2.1 shows the results for our reduced and main specifications, with peace being the omitted base category. The coefficients thus allow us to compare the choice of the two forms of violence with respect to peace. We report relative risk ratios (or odds ratios) that can be directly interpreted with respect to the quantitative effect of the variables. The exponentiated multinomial logit coefficients that we show in the table provide an estimate of the risk of the respective category relative to the omitted base category (peace). They show to what extent the relative risk ratio of an outcome changes relative to the reference group following a unit change

\footnotetext{
${ }^{25}$ The empirical evidence on the effect of democracy on terror is mixed (Sandler 1995; Gassebner and Luechinger 2011), while a negative correlation between civil war and democracy is well-established (e.g., Sambanis 2008).

${ }^{26}$ According to Enders et al. (2014), the effect of GDP per capita on terrorist attacks is non-linear in their global sample. It is arguably linear among the sample of lower-middle and middle income countries that we consider here.
} 
in a variable, for constant values of the other variables in the model. ${ }^{27}$ Odds ratios larger than one indicate a positive correlation between an explanatory variable and the respective outcome, while odds ratios less than one indicate negative relationships. By testing whether the difference between the odds ratios for our two violent outcomes is significant, we can also compare them among each other.

Table 2.1: Determinants of Terror and Insurgency, Multinomial Logit, 1980-2004

\begin{tabular}{|c|c|c|c|c|c|c|}
\hline & $\begin{array}{c}(1) \\
\text { Terror }\end{array}$ & $\begin{array}{c}(2) \\
\text { Insurgency }\end{array}$ & $\begin{array}{c}(3) \\
\text { Terror }\end{array}$ & $\begin{array}{c}(4) \\
\text { Insurgency }\end{array}$ & $\begin{array}{c}(5) \\
\text { Terror }\end{array}$ & $\begin{array}{c}(6) \\
\text { Insurgency }\end{array}$ \\
\hline Log(Group oil production) & $\begin{array}{l}1.0505 \\
(0.556)\end{array}$ & $\begin{array}{l}1.3027^{*} \\
(0.074)\end{array}$ & $\begin{array}{l}1.0237 \\
(0.733)\end{array}$ & $\begin{array}{c}1.3523^{* * *} \\
(0.004)\end{array}$ & $\begin{array}{l}0.9863 \\
(0.863)\end{array}$ & $\begin{array}{c}1.3739^{* * *} \\
(0.000)\end{array}$ \\
\hline Log(National oil production) & $\begin{array}{l}0.9316 \\
(0.374)\end{array}$ & $\begin{array}{l}0.7928 \\
(0.118)\end{array}$ & $\begin{array}{l}0.9694 \\
(0.635)\end{array}$ & $\begin{array}{c}0.8094^{* *} \\
(0.048)\end{array}$ & $\begin{array}{l}1.0113 \\
(0.897)\end{array}$ & $\begin{array}{c}0.7995^{* *} \\
(0.040)\end{array}$ \\
\hline Goal: Eliminate discrimination & & & $\begin{array}{l}2.3900 \\
(0.372)\end{array}$ & $\begin{array}{l}3.5440 \\
(0.428)\end{array}$ & $\begin{array}{l}4.6385 \\
(0.192)\end{array}$ & $\begin{array}{c}15.4623 \\
(0.125)\end{array}$ \\
\hline Goal: Autonomy, independence & & & $\begin{array}{l}0.2933 \\
(0.253)\end{array}$ & $\begin{array}{c}0.1286 \\
(0.212)\end{array}$ & $\begin{array}{l}0.2305 \\
(0.205)\end{array}$ & $\begin{array}{l}0.7397 \\
(0.870)\end{array}$ \\
\hline Goal: Eliminate economic discrimination & & & $\begin{array}{l}0.6957 \\
(0.761)\end{array}$ & $\begin{array}{c}6.5291 \\
(0.231)\end{array}$ & $\begin{array}{l}0.4010 \\
(0.430)\end{array}$ & $\begin{array}{l}5.9578 \\
(0.166)\end{array}$ \\
\hline Goal: Eliminate cultural discrimination & & & $\begin{array}{l}0.9944 \\
(0.994)\end{array}$ & $\begin{array}{l}1.1051 \\
(0.910)\end{array}$ & $\begin{array}{c}0.4422 \\
(0.263)\end{array}$ & $\begin{array}{l}0.7651 \\
(0.757)\end{array}$ \\
\hline Group supported by foreign state & & & $\begin{array}{c}4.3188^{* * *} \\
(0.003)\end{array}$ & $\begin{array}{c}3.5508^{* * *} \\
(0.004)\end{array}$ & $\begin{array}{c}3.4554^{* *} \\
(0.033)\end{array}$ & $\begin{array}{c}3.0760^{* *} \\
(0.017)\end{array}$ \\
\hline Goal: Islamic state & & & $\begin{array}{l}3.8189 \\
(0.326)\end{array}$ & $\begin{array}{l}2.7597 \\
(0.631)\end{array}$ & $\begin{array}{l}7.5744 \\
(0.208)\end{array}$ & $\begin{array}{l}4.5127 \\
(0.528)\end{array}$ \\
\hline State uses violence against group & & & $\begin{array}{c}3.1923^{* *} \\
(0.018)\end{array}$ & $\begin{array}{l}2.0715 \\
(0.175)\end{array}$ & $\begin{array}{c}9.5612^{* * *} \\
(0.000)\end{array}$ & $\begin{array}{c}3.6533^{*} \\
(0.068)\end{array}$ \\
\hline State negotiated with organisation & & & $\begin{array}{c}0.3487^{* *} \\
(0.038)\end{array}$ & $\begin{array}{l}0.5955 \\
(0.376)\end{array}$ & $\begin{array}{c}0.3139^{*} \\
(0.057)\end{array}$ & $\begin{array}{l}1.0216 \\
(0.969)\end{array}$ \\
\hline Group provides social services & & & $\begin{array}{c}7.8942^{* * *} \\
(0.009)\end{array}$ & $\begin{array}{c}15.7226^{* * *} \\
\quad(0.003)\end{array}$ & $\begin{array}{c}15.0198^{* * *} \\
(0.001)\end{array}$ & $\begin{array}{c}18.3152^{* * *} \\
(0.000)\end{array}$ \\
\hline Log(GDP p.c.) & & & & & $\begin{array}{c}5.6679^{* *} \\
(0.014)\end{array}$ & $\begin{array}{l}2.3939 \\
(0.165)\end{array}$ \\
\hline $\log ($ Population $)$ & & & & & $\begin{array}{l}0.8819 \\
(0.691)\end{array}$ & $\begin{array}{l}1.2537 \\
(0.621)\end{array}$ \\
\hline Freedom House & & & & & $\begin{array}{l}1.9433^{*} \\
(0.056)\end{array}$ & $\begin{array}{l}1.2300 \\
(0.558)\end{array}$ \\
\hline Ethnolinguistic Fractionalisation & & & & & $\begin{array}{l}0.3019 \\
(0.582)\end{array}$ & $\begin{array}{c}161.61^{* *} \\
(0.029)\end{array}$ \\
\hline Number of groups & \multicolumn{2}{|c|}{112} & \multicolumn{2}{|c|}{107} & \multicolumn{2}{|c|}{105} \\
\hline $\begin{array}{l}\text { Number of observations } \\
\text { Log-Likelihood }\end{array}$ & \multicolumn{2}{|c|}{$\begin{array}{c}5,031 \\
-865.122\end{array}$} & \multicolumn{2}{|c|}{$\begin{array}{c}4,146 \\
-644.080\end{array}$} & \multicolumn{2}{|c|}{3,360} \\
\hline
\end{tabular}

We start with only including our two oil variables without any control variables (columns 1 and 2 of Table 2.1) before adding group characteristics (columns 3 and 4) and finally estimating the

\footnotetext{
${ }^{27}$ See http://www.ats.ucla.edu/stat/stata/output/stata_mlogit_output.htm (accessed April 23, 2014).
} 
full model (without any interactions, columns 5 and 6). As can be seen, ethno-political groups are more likely to engage in insurgencies the higher the value of the oil resources that were extracted from their territory in the previous year. ${ }^{28}$ This effect is robust across the different specifications. The odds ratios in columns 2,4 , and 6 of Table 2.1 are significant at the ten (column 2) and at the one (columns 4 and 6) per cent levels and indicate that the odds of a group being involved in an insurgency rather than in peaceful activities increase by a factor of 1.37 (full model, column 6) with an increase in the logged value of oil production in the group's area by one (its mean being 7.55). There is no evidence that resource abundance in the group's territory affects its choice of terrorism versus peace, however (this can be seen from columns 1, 3 , and 5 of Table 2.1). These results point to the absence of grievances arising from the extraction of oil strong enough to induce terrorism among the countries and years in our sample. Thus, regarding our first hypothesis, it appears that the effect of oil on insurgencies reported previously in the literature finds support at the sub-national level, while we do not estimate a significant relationship with terrorism. Also when comparing the coefficients for the two violent outcomes, oil makes civil wars significantly more likely than terror (p-value 0.0009).

Regarding the control variables of the models, the results in Table 2.1 show that the groups' official goals do not appear to make a difference regarding their pursuing these aims in a peaceful or violent manner. In contrast, aiming at eliminating economic discrimination is significantly more related to large-scale violence than to terrorism. Having the support of a foreign state makes both forms of violence more likely - all odds ratios in columns 3 to 6 are larger than one and significant at the 1 per cent level. There is no significant difference between the two outcomes in this regard (p-value 0.8561). A state using violence against a group robustly increases the likelihood of this group turning to terrorism, while the same is only true for insurgencies in the full model (column 6), but even here the impact is significantly larger for terrorist activities than for insurgencies (p-value 0.04). Negotiations are found to have a negative effect on the probability of terrorism (significant at the 5 and 10 per cent level), thus giving an indication of potential negotiating success rather than group members trying to spoil negotiations with increased violence. Whether a group provides social services - our proxy for the degree of organisation - is positively associated with both forms of violence, the effect being significant at the 1 per cent level in all specifications (columns 3 to 6 ).

As pointed out above, we do not put a lot of weight on the national control variables due to the small number of countries and territories in the sample. Overall, the effect of oil production

\footnotetext{
${ }^{28}$ There might be reverse causality even though we lag oil resources by one year, so that violence reduces the amount of oil produced. In this case the estimated coefficient would reflect a lower bound for the effect of oil abundance on conflict. Also note that our results hold when we use the dummy for the existence of oil fields rather than oil production below, which is arguably exogenous to conflict.
} 
at the national level is not robustly significant. When adding group characteristics (column 4) and country-level variables (column 6), however, it seems that extracting fossil fuels somewhere on the national territory decreases the probability of violent outbreaks, possibly due to positive spill-overs from these regions in terms of social services or employment. ${ }^{29}$ Focusing on the full model (i.e., columns 5 and 6), both richer and less democratic (or less 'free') countries are more likely to face terrorist attacks but not to be confronted with larger scale challenges. ${ }^{30}$ While the positive relationship between per capita GDP and terrorism is in line with the literature above, the negative association between democracy and terrorism is not, and might arise both from the specificities of the region under observation or the small sample size. On the other hand, ethnolinguistic fractionalisation has a large and positive effect on insurgency (as found by other authors before) but does not appear to be linked to terror. This is also confirmed by the significant difference between the two odds ratios in columns 5 and 6 (p-value 0.003).

Table 2.2: Determinants of Terror and Insurgency, Multinomial Logit, 1980-2004, Political Participation

\begin{tabular}{|c|c|c|c|c|}
\hline & $\begin{array}{c}\text { (1) } \\
\text { Terror }\end{array}$ & $\begin{array}{c}(2) \\
\text { Insurgency }\end{array}$ & $\begin{array}{c}(3) \\
\text { Terror }\end{array}$ & $\begin{array}{c}(4) \\
\text { Insurgency }\end{array}$ \\
\hline Log(Group oil production) & $\begin{array}{l}0.9353 \\
(0.464)\end{array}$ & $\begin{array}{c}1.2995^{* * *} \\
(0.002)\end{array}$ & $\begin{array}{l}0.9510 \\
(0.565)\end{array}$ & $\begin{array}{c}1.574^{* * *} \\
(0.000)\end{array}$ \\
\hline Log(National oil production) & $\begin{array}{l}1.1241 \\
(0.268)\end{array}$ & $\begin{array}{c}0.7694^{* * *} \\
(0.022)\end{array}$ & $\begin{array}{c}1.8782^{* *} \\
(0.013)\end{array}$ & $\begin{array}{c}0.7794^{* *} \\
(0.050)\end{array}$ \\
\hline Interaction term oil and political discrimination & $\begin{array}{l}1.0011 \\
(0.960)\end{array}$ & $\begin{array}{l}1.0445 \\
(0.108)\end{array}$ & & \\
\hline Political discrimination & $\begin{array}{c}1.8595^{* *} \\
(0.038)\end{array}$ & $\begin{array}{l}0.6683 \\
(0.255)\end{array}$ & & \\
\hline Interaction term oil and power sharing & & & $\begin{array}{l}1.0757 \\
(0.440)\end{array}$ & $\begin{array}{c}0.7439^{* * *} \\
(0.001)\end{array}$ \\
\hline Ethnic group shares power with others & & & $\begin{array}{l}3.2593 \\
(0.375) \\
\end{array}$ & $\begin{array}{c}15.5840^{*} \\
(0.082)\end{array}$ \\
\hline Number of groups & & 103 & & 88 \\
\hline Number of observations & &, 366 & & 2,496 \\
\hline Log-Likelihood & -41 & 4.307 & & -308.901 \\
\hline
\end{tabular}

We next turn to our second hypothesis, testing whether the effect of oil extraction on the "choice of weapon' depends on possibilities of political participation of the ethnic group. As is well known, interpreting the significance of interaction effects in nonlinear models such as ours might not be straightforward. However, these difficulties do not pertain to incidence rate ratios, which rely on a multiplicative rather than an additive scale (Buis 2010). In this case, the interaction

\footnotetext{
${ }^{29}$ Higher national oil production could also mean that the state is richer and more powerful. Yet, this channel should be controlled for by including GDP per capita.

${ }^{30}$ The Freedom House indicator ranges from 1 representing 'free' to 7 'not free' so that higher values indicate lower levels of democracy.
} 
reflects the ratio of the odds ratios of the two interacted variables (which do not depend on the values of the other variables in the model) and the significance of the incidence ratio is correctly calculated.

An ethnic group is considered to be increasingly politically discriminated against if a group is not only politically under-represented but if, additionally, there are either no measures taken to remedy the situation or even measures introduced that further restrict the group's political participation relative to other groups. We take this variable from the Minorities at Risk (2009) database. In order to measure whether an ethnic group represented by an organisation in our sample has a share in central political power, we rely on a variable from the Ethnic Power Relations dataset (Wimmer et al. 2009). As presented in Table 2.2, the overall positive and highly significant (at the 1 per cent level) odds ratio for local oil production is robust to the inclusion of the interaction terms (columns 2 and 4). It can be seen that while political grievances per se do on average increase the probability of terror by a factor of 1.8 (column 1 ), we do not find an effect conditional on regional fuel extraction for either type of violence (columns 1 and 2 ). While this is in line with our assumption of terrorism being a more political phenomenon than insurgency the effect does not appear to be linked to natural resources. In contrast, the diminishing effect of power sharing on the relationship between oil and civil war finds support in column $4 .^{31}$ This result is in line with our hypothesis that groups that participate in power are less likely to choose violent over peaceful means. It is also in line with Hunziker and Cederman's (2012) observation that the risk of civil war as a consequence of resource abundance is linked to those groups that are excluded from central power.

Columns 1 and 2 of Table 2.3 present the results for our third hypothesis, including an interaction term between our indicator of resource abundance and a binary variable indicating whether or not an ethnic group enjoyed regional autonomy. This information is also taken from the EPR database (Wimmer et al. 2009). It can be seen that when it comes to autonomy, the effect for both forms of violence is exactly opposing one another: While regional autonomy appears to make terrorism less likely in combination with oil reserves (column 1), it increases the probability of violent conflict (column 2). This is in line with Sambanis (2008), showing economic factors to be relatively important for civil wars, while terrorist activities are predominantly driven by political aspects. Political grievances over the appropriation of fuel revenues are largely addressed by the status of regional autonomy while only independence grants full economic control. The finding regarding civil war is also in accordance with Ross' (2004) result that regions where ethnic groups strive for more autonomy might be driven into secessionist wars where financial

\footnotetext{
${ }^{31}$ The number of observation is noticeably reduced in columns 3 and 4 because the EPR data are not available for Bahrain, Cyprus or the Palestinian territories.
} 
Table 2.3: Determinants of Terror and Insurgency, Multinomial Logit, 1980-2004, Autonomy and Economic Discrimination

\begin{tabular}{|c|c|c|c|c|}
\hline & $\begin{array}{c}(1) \\
\text { Terror }\end{array}$ & $\begin{array}{c}(2) \\
\text { Insurgency }\end{array}$ & $\begin{array}{c}(3) \\
\text { Terror }\end{array}$ & $\begin{array}{c}(4) \\
\text { Insurgency }\end{array}$ \\
\hline Log(Group oil production) & $\begin{array}{l}1.0168 \\
(0.801)\end{array}$ & $\begin{array}{c}1.3070^{* * *} \\
(0.000)\end{array}$ & $\begin{array}{l}0.9763 \\
(0.777)\end{array}$ & $\begin{array}{c}1.3220^{* * *} \\
(0.001)\end{array}$ \\
\hline Log(National oil production) & $\begin{array}{c}1.6052^{* *} \\
(0.046)\end{array}$ & $\begin{array}{l}0.8466 \\
(0.101)\end{array}$ & $\begin{array}{l}1.1082 \\
(0.275)\end{array}$ & $\begin{array}{c}0.8107^{* *} \\
(0.036)\end{array}$ \\
\hline Interaction term oil and autonomy & $\begin{array}{c}0.2985^{* *} \\
(0.011)\end{array}$ & $\begin{array}{c}1.2488^{* *} \\
(0.020)\end{array}$ & & \\
\hline Ethnic group has regional autonomy & $\begin{array}{l}0.4640 \\
(0.486)\end{array}$ & $\begin{array}{l}0.1562 \\
(0.347)\end{array}$ & & \\
\hline Interaction term oil and economic discrimination & & & $\begin{array}{l}0.9958 \\
(0.865)\end{array}$ & $\begin{array}{l}1.0137 \\
(0.674)\end{array}$ \\
\hline Economic discrimination & & & $\begin{array}{c}2.0703^{* * *} \\
(0.005)\end{array}$ & $\begin{array}{l}0.8947 \\
(0.735)\end{array}$ \\
\hline Number of groups & \multicolumn{2}{|c|}{88} & \multicolumn{2}{|r|}{103} \\
\hline Number of observations & \multirow{2}{*}{\multicolumn{2}{|c|}{2,517}} & \multicolumn{2}{|c|}{$\begin{array}{c}3,366 \\
-415,383\end{array}$} \\
\hline Log-Likelihood & & -315.477 & \multicolumn{2}{|c|}{-415.383} \\
\hline
\end{tabular}

incentives from natural resources are available.

Columns 3 and 4 of Table 2.3 turn to our fourth hypothesis, testing the impact of economic discrimination or inequality. The findings resemble those for political discrimination in that economic discrimination per se increases the probability for terrorism twofold (column 3) but does not appear to be related to insurgencies or have a differential effect in oil-extracting areas.

The results for our fifth hypothesis - expecting support by a foreign state to increase the likelihood for insurgency in oil-rich regions due to increased strength of the group relative to the central state and also based on higher stakes for the supporting state — yields some interesting insights: While in column 1 of Table 2.4 it can be seen that foreign state support per se remains significant at the ten per cent level (just as in the previous specifications), indicating that groups supported from abroad are 2.7 times more likely to resort to terrorism, the interaction term is not significantly different from zero. Thus, although organisations with foreign assistance resort to violence more often, in the case of terrorist activities this seems to be independent from oil. In contrast, just as discussed by Ross (2004), the high possible income from fossil fuels seems to encourage foreign states to back up groups in larger scale insurgencies (column 2), while the support as such is no longer significant, indicating that here sponsorship is indeed related to mineral resources.

In summary, we find evidence in line with the 'resource curse' in relation to large-scale violence 
Table 2.4: Determinants of Terror and Insurgency, Multinomial Logit, 1980-2004, Support by Foreign State

\begin{tabular}{|c|c|c|}
\hline & $\begin{array}{c}(1) \\
\text { Terror }\end{array}$ & $\begin{array}{c}(2) \\
\text { Insurgency }\end{array}$ \\
\hline Log(Group oil production) & $\begin{array}{l}0.9709 \\
(0.716)\end{array}$ & $\begin{array}{c}1.3192^{* * *} \\
(0.004)\end{array}$ \\
\hline Log(National oil production) & $\begin{array}{l}1.0092 \\
(0.915)\end{array}$ & $\begin{array}{c}0.7960^{* *} \\
(0.039)\end{array}$ \\
\hline Interaction term oil and foreign support & $\begin{array}{l}1.0788 \\
(0.192)\end{array}$ & $\begin{array}{c}1.1511^{* *} \\
(0.037)\end{array}$ \\
\hline Group supported by foreign state & $\begin{array}{l}2.7315^{*} \\
(0.094)\end{array}$ & $\begin{array}{l}1.6774 \\
(0.225)\end{array}$ \\
\hline Number of groups & & 105 \\
\hline Number of observations & & 3,360 \\
\hline Log-Likelihood & & -421.664 \\
\hline \multicolumn{3}{|c|}{$\begin{array}{l}\text { Notes: Odds ratios shown. Additional control variables (as in the main } \\
\text { specifications) are included in all regressions but not shown. } \\
\text { p-values in parentheses. }{ }^{*} p<0.10,{ }^{* *} p<0.05,{ }^{* * *} p<0.01 \\
\text { All variables are lagged by one year and standard errors are clustered at the } \\
\text { organisation level. }\end{array}$} \\
\hline
\end{tabular}

but not when it comes to terrorism. In our approach to differentiating the two, we find political and economic discrimination to increase terrorism, but independent of oil resources. However, while power sharing can mitigate the escalating impact of mineral resources, in areas that strive for more independence (as shown in their status of autonomy), the prospect of high revenues appears to induce insurgencies. Similarly, foreign states' involvement in regions with fossil fuel reserves is likely to spark civil wars while it increases terrorism independently from oil.

\subsubsection{Tests for Robustness}

Appendix A3 tests the robustness of our main results to using PRIO's binary indicator for the existence of oil fields rather than oil extraction. As described above, this database also includes small fields but does not measure the degree of resource abundance. Furthermore, this indicator hardly varies within groups and it is constant over time within the same region. It is likely that it is this loss in power which leads to one change in the results of this robustness check compared to the main results: Considering our hypothesis 1, the relationship between fossil fuels and both forms of violence is no longer robustly significant, in three out of six specifications oil reserves in the region of a group now make terrorist activities significantly less likely than peace (in line with Tavares 2004). Possibly here, revenues from resource extraction are spent at the advantage of the local population, offsetting potential grievances that might exist.

However, with this oil indicator, the likelihood of insurgency rather than terrorism is still significantly higher, in line with the main findings. We are also able to reproduce all the findings from the models including interaction terms. Overall, our main results are thus robust to using 
the alternative measure of resource abundance.

Appendix A4 presents a number of further tests for robustness. Columns 1 and 2 show our main specification with standard errors clustered at the country rather than at the organisation level. Columns 3 and 4 apply the Polity IV (Marshall et al. 2014) rather than the Freedom House measure for democracy. As Polity IV does not include the Palestinian territories, we did not use it in the analysis above, although it is the more commonly used used indicator of democracy (e.g., Schneider 2014). Finally, columns 5 and 6 replace ethnolinguistic fractionalisation with polarisation (Montalvo and Reynal-Querol 2005), as Montalvo and Reynal-Querol (2005) and others argue that a measure of polarisation should capture the non-monotonic relationship between ethnic diversity and conflict better than an index of fractionalisation. Again, the number of observations is noticeably reduced as this measure is not available for Lebanon and the Palestinian territories. These three variations leave our main findings unchanged.

\subsection{Conclusion}

In this chapter we investigate what determines ethno-political organisations' choice between pursuing their goals with peaceful means or violent action, distinguishing between smaller-scale terrorist activities and larger scale insurgencies. According to our theory, the extraction of natural resources exerts externalities on ethnic groups populating the regions where resources are extracted, leading to grievances. At the same time, revenues from fossil fuels represent important economic incentives. The consequent risk of both terrorism and rebellion depends on the group's characteristics as well as the state's reaction to its actions. Based on this reasoning, we run a multinomial logit model where we include regional and national oil production and then add a number of interaction terms representing these factors. Indeed, our results show that insurgencies are more likely with greater resource extraction, both with respect to peace and with respect to terrorism. The choice to take up arms for terrorist activities is not affected by resource availability however.

Access to a share in political power reduces the likelihood of insurgencies. While Hunziker and Cederman (2012) interpret this result to indicate the importance of grievances rather than greed, ethnic groups participating in power might also be able to extract a larger share of the resources in their territory, reducing the chances of greed-based insurgencies. This reading is supported by the finding that a status of regional autonomy helps to diminish the effect of regional oil extraction on terrorist activities but even enlarges the probability of insurgencies. What is more, while economic and political grievances per se increase the risk of terrorism, this relationship appears to be independent from fossil fuel extraction. Additionally, in regions where 
oil can be extracted, foreign states' support of the political group also escalates violent processes.

Taken together, our findings indicate that natural resources are an important factor in the mobilisation for civil war, e.g., as a means for selective payments, but play less of a role in terrorist movements where a smaller degree of mobilisation is required. This is in line with the analyses of both Sambanis (2008) and Ross (2004) who also conclude that terrorism is rather driven by political than by economic factors while for civil wars greed dominates grievances as a motive for ethno-political organisations to turn violent as a consequence of oil production in the regions of the ethnicities that they represent (in line with the country level analyses in Collier and Hoeffler 2004 and Collier et al. 2009).

In addition, the regional distribution of oil matters as do specific group characteristics and an organisation's standing vis-à-vis the state. The information on all of these aspects is lost when comparing countries, as is the focus of most of the previous literature. Furthermore, although the geographical coverage of the MAROB data is limited to the MENA region, looking at groups should arguably benefit from a higher external validity as the 'rationality of actors' should be independent from their country of origin.

However, future research should take up the innovations of this paper - notably moving the 'resource-curse' literature to the sub-national level, looking at political groups, and comparing causes of violent behaviour per se as well as causes of its different forms - and include further geographical regions and natural resources. 


\subsection{Appendix}

Table A1: Descriptive Statistics and Sources

\begin{tabular}{lcccccc}
\hline \hline & Mean & SD & Min & Max & N & Source \\
\hline \hline 'Weapon of Choice' & 0.54 & 0.83 & 0 & 2 & 1120 & MAROB (Asal et al. 2008) \\
Regional Oil Production (Million US\$) & 1886.85 & 6610.29 & 0 & 76699 & 1120 & Horn (2010) \\
National Oil Production (Million US\$) & 8697.32 & 19409.70 & 0 & 162612 & 1120 & Horn (2010), Ross (2013) \\
GDP per capita & 9780.94 & 6933.81 & 2162 & 28094 & 1120 & Penn World Tables, World Development Indicators \\
Population in 1000s & 13834.36 & 17306.95 & 374 & 69342 & 1120 & World Development Indicators \\
Freedom House & 4.54 & 1.90 & 1 & 7 & 1120 & Freedom House \\
Polity IV & 0.71 & 8.13 & -10 & 10 & 761 & Marshall et al. (2014) \\
Ethnolinguistic fractionalisation & 0.50 & 0.20 & 0 & 1 & 1120 & Yeoh (2012) \\
Ethnolinguistic polarisation & 0.62 & 0.18 & 0 & 1 & 793 & Montalvo and Reynal-Querol (2005) \\
Goal: eliminate discrimination, remedial policies & 0.60 & 0.49 & 0 & 1 & 1119 & MAROB (Asal et al. 2008) \\
Goal: autonomy, independence & 0.25 & 0.44 & 0 & 1 & 1119 & MAROB (Asal et al. 2008) \\
Goal: eliminate economic discrimination & 0.19 & 0.39 & 0 & 1 & 1120 & MAROB (Asal et al. 2008) \\
Goal: eliminate cultural discrimination & 0.32 & 0.47 & 0 & 1 & 1120 & MAROB (Asal et al. 2008) \\
Group supported by foreign state & 0.35 & 0.48 & 0 & 1 & 1100 & MAROB (Asal et al. 2008) \\
Goal: Islamic state & 0.08 & 0.27 & 0 & 1 & 1120 & MAROB (Asal et al. 2008) \\
State uses violence against group & 0.13 & 0.33 & 0 & 1 & 1117 & MAROB (Asal et al. 2008) \\
Group provides social services & 0.21 & 0.41 & 0 & 1 & 1116 & MAROB (Asal et al. 2008) \\
State negotiated with organisation & 0.11 & 0.32 & 0 & 1 & 1120 & MAROB (Asal et al. 2008) \\
Economic Discrimination & 2.05 & 1.61 & 0 & 4 & 1029 & Minorities at Risk \\
Political Discrimination & 2.25 & 1.73 & 0 & 4 & 1029 & Minorities at Risk \\
Ethnic group has regional autonomy & 0.15 & 0.36 & 0 & 1 & 832 & Ethnic Power Relations (Wimmer et al. 2009) \\
Ethnic group shares political power with others & 0.18 & 0.38 & 0 & 1 & 832 & Ethnic Power Relations (Wimmer et al. 2009) \\
\hline \hline Notes: Oil production variables are displayed here in million US\$ for better clarity. They are included in totals in the analysis.
\end{tabular}

Notes: Oil production variables are displayed here in million US\$ for better clarity. They are included in totals in the analysis.

All variables except for the Oil Dummy and the ethnolinguistic fractionalisation/ polarisation vary from year to year. 
Table A2: Definition of Variables

\section{'Weapon of Choice'}

Regional Oil Production

National Oil Production

Oil Dummy

GDP per capita

Population

Freedom House

Polity IV

Ethnolinguistic fractionalisation

Ethnolinguistic polarisation
Definition

$0=$ no violent behaviour; $1=$ terrorism, i.e., attacks on civilians incl. non-security state personnel, no control of territory; $2=$ insurgency, i.e., attacks targeting security personnel and state authorities, local rebellion, guerilla activity, civil war, control of territory

Value of the share of the national hydrocarbon production in a year, located on an ethnic group's territory, in constant 2009 million US $\$$ (for fields containing at least 500 million barrels oil or gas equivalents)

Value of the national hydrocarbon production in a year in constant 2009 US $\$$ (for fields containing at least 500 million barrels oil Value of the national hydrocarbon production in a year in constant 2009 US

Indicates that hydrocarbon reserves are located on an ethnic group's territory

GDP per capita, PPP, in constant 2005 US \$

Measured in $1000 \mathrm{~s}$

Average of civil liberties and political rights indices; from $1=$ free to $7=$ not free; civil liberties: freedom of expression and belief, associational and organisational rights, rule of law, and personal autonomy and individual rights; political rights: electoral process, political pluralism and participation, and functioning of government

Polity scale ranges from +10 (strongly democratic) to -10 (strongly autocratic)

Probability that a randomly selected pair of individuals in a society will belong to different groups; from $0=$ complete homogeneity Probability that a randomly selected pair of individuals in a society will belong to different groups; from $0=$ complete homogeneity
to $1=$ complete heterogeneity

Captures the distance of the distribution of ethnic groups from the bipolar distribution, ranging from $0=$ least polarised to $1=$

Goal: eliminate discrimination, remedial policies $\begin{aligned} & \text { maximally polarised (bipolar) } \\ & \text { Majganisational goals focused on eliminating discrimination and on creating increasing remedial policies }\end{aligned}$

Goal: autonomy, independence $\quad$ Major organisational goals focused on creating or strengthening autonomous status for group or on creating a separate state for the group or revanchist change in border of state

Goal: eliminate economic discrimination

Group expresses economic grievances focused on elimination of discrimination or on creating or strengthening economic remedial policies

Group expresses cultural grievances focused on elimination of discrimination or on strengthening economic remedial policies (i.e., establishing or increasing state funding for cultural protection and/or promotion) Has the organisation received support from foreign state in year being coded - i.e., financial, humanitarian, political, or military support?

Has the organisation expressed the goal of creating an Islamic state/ an Islamic government or of introducing Islamic law?

Does the state use periodic or consistent lethal violence against the organisation?

The provision of social services is a minor or major strategy of the organisation

The state negotiated with the group in the year and the state might even have made concessions

$0=$ no discrimination, $1=$ neglect but remedial policies; $2=$ neglect, no remedial policies; $3=$ social exclusion, neutral policies; $4=$ exclusion/ repressive policy

$0=$ no discrimination, $1=$ neglect but remedial policies; $2=$ neglect, no remedial policies; $3=$ social exclusion, neutral policies; $4=$ exclusion/ repressive policy

Elite members of the group have no central power but have some influence at the subnational level (i.e., the provincial or district Elite members of the group have no central power but have

Ethnic group has regional autonomy

Ethnic group shares political power with others Any (formal or informal) arrangement that divides executive power among leaders who claim to represent particular ethnic groups Notes: Oil production variables are displayed here in million US\$ for better clarity. They are included in totals in the analysis.

All variables except for the Oil Dummy and the ethnolinguistic fractionalisation/ polarisation vary from year to year. 
Table A3: Determinants of Peace and Insurgencies, Multinomial Logit, 1980-2004, Alternative Oil Measure

\begin{tabular}{|c|c|c|c|c|c|c|c|c|c|c|c|c|}
\hline & $\begin{array}{c}(1) \\
\text { Terror }\end{array}$ & $\begin{array}{c}(2) \\
\text { Insurgency }\end{array}$ & $\begin{array}{c}(3) \\
\text { Terror }\end{array}$ & $\begin{array}{c}(4) \\
\text { Insurgency }\end{array}$ & $\begin{array}{c}(5) \\
\text { Terror }\end{array}$ & $\begin{array}{c}(6) \\
\text { Insurgency }\end{array}$ & $\begin{array}{c}(7) \\
\text { Terror }\end{array}$ & $\begin{array}{c}(8) \\
\text { Insurgency }\end{array}$ & $\begin{array}{c}(9) \\
\text { Terror }\end{array}$ & $\begin{array}{c}(10) \\
\text { Insurgency }\end{array}$ & $\begin{array}{l}(11) \\
\text { Terror }\end{array}$ & $\begin{array}{c}(12) \\
\text { Insurgency }\end{array}$ \\
\hline Oil or gas field on group's territory & $\begin{array}{l}0.0468^{* *} \\
(0.0454)\end{array}$ & $\begin{array}{c}0.339 \\
(0.534)\end{array}$ & $\begin{array}{c}0.0471 \\
(0.0778)\end{array}$ & $\begin{array}{c}0.122 \\
(0.248)\end{array}$ & $\begin{array}{l}0.0147^{* *} \\
(0.0205)\end{array}$ & $\begin{array}{c}0.440 \\
(0.946)\end{array}$ & $\begin{array}{c}0.0599 \\
(0.0993)\end{array}$ & $\begin{array}{c}0.204 \\
(0.428)\end{array}$ & $\begin{array}{l}0.0957 \\
(0.141)\end{array}$ & $\begin{array}{c}0.452 \\
(0.865)\end{array}$ & $\begin{array}{c}0.0259^{* * *} \\
(0.0269)\end{array}$ & $\begin{array}{l}0.0701 \\
(0.121)\end{array}$ \\
\hline Log(National oil production) & $\begin{array}{c}1.081 \\
(0.0551)\end{array}$ & $\begin{array}{c}1.091 \\
(0.0888)\end{array}$ & $\begin{array}{l}1.172^{*} \\
(0.0847)\end{array}$ & $\begin{array}{c}1.126 \\
(0.0941)\end{array}$ & $\begin{array}{l}1.798^{*} \\
(0.433)\end{array}$ & $\begin{array}{c}1.107 \\
(0.0795)\end{array}$ & $\begin{array}{l}1.635^{*} \\
(0.360)\end{array}$ & $\begin{array}{c}1.035 \\
(0.0932)\end{array}$ & $\begin{array}{l}1.162^{*} \\
(0.0871)\end{array}$ & $\begin{array}{c}1.084 \\
(0.0885)\end{array}$ & $\begin{array}{c}1.086 \\
(0.0540)\end{array}$ & $\begin{array}{c}1.103 \\
(0.0896)\end{array}$ \\
\hline Group supported by foreign state & $\begin{array}{l}3.951^{*} \\
(2.235)\end{array}$ & $\begin{array}{l}3.640^{* *} \\
(1.778)\end{array}$ & $\begin{array}{l}3.289^{*} \\
(1.817)\end{array}$ & $\begin{array}{l}3.581^{*} \\
(1.788)\end{array}$ & $\begin{array}{c}1.329 \\
(0.800)\end{array}$ & $\begin{array}{c}2.914 \\
(1.645)\end{array}$ & $\begin{array}{c}1.471 \\
(0.948)\end{array}$ & $\begin{array}{c}2.757 \\
(1.522)\end{array}$ & $\begin{array}{l}3.289^{*} \\
(1.898)\end{array}$ & $\begin{array}{l}3.639^{* *} \\
(1.800)\end{array}$ & $\begin{array}{c}2.996 \\
(1.725)\end{array}$ & $\begin{array}{l}1.720 \\
(0.727)\end{array}$ \\
\hline Ethnic group politically discriminated & & & $\begin{array}{l}2.085^{* *} \\
(0.489)\end{array}$ & $\begin{array}{c}1.104 \\
(0.371)\end{array}$ & & & & & & & & \\
\hline Interaction term oil and political discrimination & & & $\begin{array}{c}0.809 \\
(0.332)\end{array}$ & $\begin{array}{c}1.379 \\
(0.789)\end{array}$ & & & & & & & & \\
\hline Interaction term oil and power sharing & & & & & $\begin{array}{l}10.74 \\
(19.72)\end{array}$ & $\begin{array}{l}0.0147^{*} \\
(0.0305)\end{array}$ & & & & & & \\
\hline Ethnic group shares political power with others & & & & & $\begin{array}{c}0.994 \\
(1.220)\end{array}$ & $\begin{array}{c}1.118 \\
(1.861)\end{array}$ & & & & & & \\
\hline Interaction term oil and regional autonomy & & & & & & & $\begin{array}{c}0.00000886^{* * *} \\
(0.0000138)\end{array}$ & $\begin{array}{l}234.6^{*} \\
(517.7)\end{array}$ & & & & \\
\hline Ethnic group has regional autonomy & & & & & & & $\begin{array}{c}0.484 \\
(0.483)\end{array}$ & $\begin{array}{c}0.208 \\
(0.391)\end{array}$ & & & & \\
\hline Ethnic group economically discriminated & & & & & & & & & $\begin{array}{l}1.989^{* *} \\
(0.503)\end{array}$ & $\begin{array}{l}1.027 \\
(0.340)\end{array}$ & & \\
\hline Interaction term oil and economic discrimination & & & & & & & & & $\begin{array}{c}0.792 \\
(0.394)\end{array}$ & $\begin{array}{c}0.831 \\
(0.616)\end{array}$ & & \\
\hline Interaction term oil and foreign support & & & & & & & & & & & $\begin{array}{c}5.315 \\
(5.990) \\
\end{array}$ & $\begin{array}{l}38.40^{*} \\
(57.61) \\
\end{array}$ \\
\hline Number of groups & \multicolumn{2}{|c|}{105} & \multicolumn{2}{|c|}{103} & \multicolumn{2}{|c|}{88} & \multicolumn{2}{|c|}{88} & \multicolumn{2}{|c|}{103} & \multicolumn{2}{|c|}{105} \\
\hline Number of observations & \multirow{2}{*}{\multicolumn{2}{|c|}{$\begin{array}{c}3,360 \\
-424.049\end{array}$}} & \multirow{2}{*}{\multicolumn{2}{|c|}{$\begin{array}{c}3,336 \\
-416.696\end{array}$}} & \multirow{2}{*}{\multicolumn{2}{|c|}{$\begin{array}{c}2,517 \\
-317.374\end{array}$}} & \multirow{2}{*}{\multicolumn{2}{|c|}{$\begin{array}{c}2,517 \\
-317.2555\end{array}$}} & \multirow{2}{*}{\multicolumn{2}{|c|}{$\begin{array}{c}3,336 \\
-417.753\end{array}$}} & \multirow{2}{*}{\multicolumn{2}{|c|}{$\begin{array}{c}3,360 \\
-420.463\end{array}$}} \\
\hline Log-Likelihood & & & & & & & & & & & & \\
\hline
\end{tabular}

Notes: Odds ratios shown. Additional control variables (as in main specifications) are included in all regressions but not shown.

p-values in parentheses: ${ }^{*} p<0.05,{ }^{* *} p<0.01,{ }^{* * *} p<0.001$

All variables are lagged by one year and standard errors are clustered at the organisation level. 
Table A4: Determinants of Peace and Insurgencies, Multinomial Logit, 1980-2004, Alternative Specifications/ Covariates

\begin{tabular}{|c|c|c|c|c|c|c|}
\hline & $\begin{array}{c}(1) \\
\text { Terror }\end{array}$ & $\begin{array}{c}(2) \\
\text { Insurgency }\end{array}$ & $\begin{array}{c}(3) \\
\text { Terror }\end{array}$ & $\begin{array}{c}(4) \\
\text { Insurgency }\end{array}$ & $\begin{array}{c}(5) \\
\text { Terror }\end{array}$ & $\begin{array}{c}(6) \\
\text { Insurgency }\end{array}$ \\
\hline Log(Group oil production) & $\begin{array}{l}0.9863 \\
(0.895)\end{array}$ & $\begin{array}{c}1.3739^{* * *} \\
(0.000)\end{array}$ & $\begin{array}{l}0.9019 \\
(0.459)\end{array}$ & $\begin{array}{c}1.7575^{* * *} \\
(0.001)\end{array}$ & $\begin{array}{l}1.0095 \\
(0.909)\end{array}$ & $\begin{array}{c}1.4787^{* * *} \\
(0.003)\end{array}$ \\
\hline $\log ($ National oil production) & $\begin{array}{l}1.0113 \\
(0.920)\end{array}$ & $\begin{array}{c}0.7995^{* * *} \\
(0.000)\end{array}$ & $\begin{array}{l}1.0720 \\
(0.568)\end{array}$ & $\begin{array}{c}0.7917^{*} \\
(0.089)\end{array}$ & $\begin{array}{l}1.1677 \\
(0.209)\end{array}$ & $\begin{array}{l}0.9091 \\
(0.546)\end{array}$ \\
\hline Group supported by foreign state & $\begin{array}{l}3.4554 \\
(0.154)\end{array}$ & $\begin{array}{c}3.0760^{* *} \\
(0.046)\end{array}$ & $\begin{array}{c}6.4668^{*} \\
(0.063)\end{array}$ & $\begin{array}{l}3.1417 \\
(0.269)\end{array}$ & $\begin{array}{l}5.7551 \\
(0.130)\end{array}$ & $\begin{array}{l}4.4281 \\
(0.190)\end{array}$ \\
\hline State uses violence against group & $\begin{array}{c}9.5612^{* * *} \\
(0.000)\end{array}$ & $\begin{array}{c}3.6533^{* * *} \\
(0.005)\end{array}$ & $\begin{array}{l}2.2435 \\
(0.321)\end{array}$ & $\begin{array}{l}3.4627 \\
(0.269)\end{array}$ & $\begin{array}{l}4.3496^{*} \\
(0.054)\end{array}$ & $\begin{array}{l}5.5114 \\
(0.117)\end{array}$ \\
\hline State negotiated with organisation & $\begin{array}{c}0.3139^{*} \\
(0.081)\end{array}$ & $\begin{array}{l}1.0216 \\
(0.974)\end{array}$ & $\begin{array}{c}5.85 \mathrm{e}-08 \\
(0.198)\end{array}$ & $\begin{array}{l}1.2403 \\
(0.682)\end{array}$ & $\begin{array}{l}0.3296 \\
(0.398)\end{array}$ & $\begin{array}{l}0.4623 \\
(0.294)\end{array}$ \\
\hline Group provides social services & $\begin{array}{c}15.0198^{* * *} \\
(0.000)\end{array}$ & $\begin{array}{c}18.3152^{* * *} \\
(0.000)\end{array}$ & $\begin{array}{c}12.3340^{* * *} \\
(0.008)\end{array}$ & $\begin{array}{c}45.8325^{* * *} \\
(0.000)\end{array}$ & $\begin{array}{c}24.5443^{* * *} \\
(0.003)\end{array}$ & $\begin{array}{c}17.8276^{* * *} \\
(0.005)\end{array}$ \\
\hline $\log ($ GDP p.c.) & $\begin{array}{c}5.6679^{* * *} \\
(0.002)\end{array}$ & $\begin{array}{l}2.3939 \\
(0.439)\end{array}$ & $\begin{array}{c}29.3888^{* * *} \\
\quad(0.004)\end{array}$ & $\begin{array}{l}1.1277 \\
(0.888)\end{array}$ & $\begin{array}{l}2.7998 \\
(0.372)\end{array}$ & $\begin{array}{c}17.9102^{* *} \\
(0.024)\end{array}$ \\
\hline $\log ($ Population $)$ & $\begin{array}{l}0.8819 \\
(0.737)\end{array}$ & $\begin{array}{l}1.2537 \\
(0.515)\end{array}$ & $\begin{array}{l}1.8560 \\
(0.216)\end{array}$ & $\begin{array}{l}1.4555 \\
(0.508)\end{array}$ & $\begin{array}{l}0.9956 \\
(0.993)\end{array}$ & $\begin{array}{l}2.9022 \\
(0.245)\end{array}$ \\
\hline Freedom House & $\begin{array}{c}1.9433^{* *} \\
(0.015)\end{array}$ & $\begin{array}{l}1.2302 \\
(0.716)\end{array}$ & & & $\begin{array}{l}0.6373 \\
(0.473)\end{array}$ & $\begin{array}{l}0.8620 \\
(0.775)\end{array}$ \\
\hline Polity IV & & & $\begin{array}{c}0.8312^{* *} \\
(0.016)\end{array}$ & $\begin{array}{c}1.4052^{* * *} \\
(0.001)\end{array}$ & & \\
\hline Ethnolinguistic Fractionalisation & $\begin{array}{l}0.3019 \\
(0.571)\end{array}$ & $\begin{array}{c}161.61^{* *} \\
(0.019)\end{array}$ & $\begin{array}{c}13.5016 \\
(0.667)\end{array}$ & $\begin{array}{c}4.53 \mathrm{e}+06^{* * *} \\
(0.000) "\end{array}$ & & \\
\hline Ethnoliguistic Polarisation & & & & & $\begin{array}{c}0.0007^{*} \\
(0.054)\end{array}$ & $\begin{array}{c}469.8275 \\
(0.315)\end{array}$ \\
\hline $\begin{array}{l}\text { Number of groups } \\
\text { Number of observations } \\
\text { Log-Likelihood }\end{array}$ & $\begin{array}{r}1 \\
3, \\
-424\end{array}$ & 105 & \multicolumn{2}{|c|}{$\begin{array}{c}2,409 \\
-220.672\end{array}$} & $\begin{array}{r}8 \\
2, \\
-226\end{array}$ & $\begin{array}{l}30 \\
379 \\
6.723\end{array}$ \\
\hline $\begin{array}{l}\text { Notes: Odds ratios shown. Ad } \\
\text { regressions but not shown. All } \\
\text { at the organisation (columns } 3\end{array}$ & onal contr & ntry level & $\begin{array}{l}\text { (as in mai } \\
\text { one year an }\end{array}$ & $\begin{array}{l}\text { specificati } \\
\text { d standard } \\
\text { ad 2). }\end{array}$ & $\begin{array}{l}\text { ns) are inclu } \\
\text { rors are clu }\end{array}$ & $\begin{array}{l}\text { ded in all } \\
\text { stered }\end{array}$ \\
\hline
\end{tabular}




\title{
3 Their Suffering, Our Burden? How Congolese Refugees Affect the Ugandan Population
}

\begin{abstract}
This paper analyses the impact of both the long-term presence and additional influxes of refugees on the local population in Uganda. Uganda has a unique legal framework of local integration which makes it an interesting case to study. Two different household surveys covering the years 2002-' 10 are used in order to employ a difference-in-differences approach. In doing so, the natural experiment of two sudden inflows is exploited, while simultaneously controlling for long-term trends in refugee numbers. The findings presented here suggest that the Ugandan population living nearby refugee settlements benefits both in terms of consumption and public service provision. However, their negative perceptions regarding their own economic situation and their alienation from their national identity contradict this objective improvement of livelihoods.
\end{abstract}

\subsection{Introduction}

The Second Congo War has also been named Africa's World War, referencing its disastrous impact as the deadliest conflict since World War II. Especially in the East of the country, millions have become internally displaced or fled to neighbouring states. In Uganda, having a history of recent civil war itself, the accommodation of refugees was initially met with popular support. However, as their situation became increasingly protracted and their return was not conceivable, reluctance developed as they were perceived to become a burden on public infrastructure and a source of competition in the labour market.

Similarly, the number of protracted refugee situations, i.e., those that have been lasting for more than five years (Crisp 2003) has globally increased from 22 in 1999 to 33 by the end of 2013 (United Nations High Commissioner for Refugees 2014), with refugees living in uncertainty about their future for an average of 17 years (Jacobsen 2002). For a long time, refugee policies largely had an emergency aid type of character, caring for them in camps and aiming at sending them home or to third countries as fast as possible. In 2005, however, the United Nations High Commissioner for Refugees (UNHCR) performed a policy shift towards their local integration (United Nations High Commissioner for Refugees 2005). In a background note in the World Development Report 2011, the World Bank also acknowledges the 'development challenge' that exists due to the impact of refugees on their neighbouring countries (Puerto Gomez and Christensen 2010).

I thank the members of the Development Economics Research Group at the University of Goettingen, participants of the HiCN workshop 2013 in Berkeley and the CSAE Conference 2014 in Oxford as well as the members of the RTG Globalisation and Development for helpful feedback. Funding by the German Research Foundation (DFG) is gratefully acknowledged. In addition, the Refugee Law Project provided logistical support and invaluable guidance in the field while UNHCR Uganda shared data. 
The Ugandan government has followed a political process from stressing the aim of economic self-reliance of the refugees to its Refugee Act of 2006/9 that promotes local integration of refugees and aims at merging public services for Ugandans and the displaced to both groups' advantage. ${ }^{32}$ This approach differs from the well-known approach of 'refugee warehousing.' But integration cannot be carried out if the hosts are reluctant to include the foreigners into their society and economy because they feel - and possibly rightfully so - that the latters' presence is to the formers' disadvantage (Fielden 2008).

Uganda has been facing two linked but distinct challenges: Together with the international community, it has to simultaneously provide emergency aid and long-term development support and find a transition from one to the other. Arriving refugees need to receive basic goods and services while at the same time sustainable health and education systems as well as employment opportunities should be open to those persons that have to stay longer. Both of these tasks run the risk of being fulfilled at the cost of the local Ugandan population due to a tight public budget and an economic environment that is sensitive to externally induced changes in supply and demand. While the presence of refugees will always have an effect on the local population, this impact is likely to be much more pronounced in the Ugandan context of local integration.

The purpose of this chapter, then, is threefold: First, the degree to which the declared political goals of the Refugee Act - economic activity independent of aid and inclusion of public services - impact the situation of the host population is analysed. This is done by looking at household welfare in terms of consumption and at the accessibility of health and primary education institutions. This is based on the hypothesis that the presence of refugees has an impact on the economic welfare of the population of surrounding areas, depending on the persons' source of income. This might be through either price effects or competition in the (labour) market. Furthermore, it is expected that when opening up public services provided by international aid donors to the host population, the general availability of services increases, while when allowing refugees to access state-run services, funds are redirected away from services for nationals. In addition to these objective measures, the subjective view of the local population of their economic situation and in how far they identify with their national state is taken into account. The presence of a large number of foreigners will impact the population's perceptions. As important stakeholders in the integration process, these have to be considered. Third, the impact of the long-term development of the refugee population is differentiated from the effect of short-term variations (or shocks) to distinguish the general trend from emergency situations.

Three waves $(2002,2005,2010)$ of two different household surveys are used, respectively, in order

\footnotetext{
${ }^{32}$ The Refugee Act was drafted in 2006 but passed in 2009.
} 
to employ a difference-in-differences approach, comparing the effect of additional refugees on the three outcomes described above in refugee-hosting areas with the control group of non-hosting districts. The findings presented here suggest that Uganda can benefit from its decades long experience of hosting refugees and providing for internally displaced persons as well as its exemplary policy framework. There is an overall significantly positive effect of refugee presence on households' consumption that is superposed in times of sudden additional influx for income groups competing with refugees in the labour market. Regarding public services, results show that in terms of education, the non-governmental organisations and other private agencies help the state to cope with the additional demand for services while this functions less well in the health sector. However, Ugandans living in the surrounding areas of refugee settlements have more negative views on their present economic situation and feel more alienated from their central government. This could motivate policy makers to look further into this issue and possibly increase efforts to reduce prejudices between the groups.

This chapter is organised as follows: First, the chapter summarises the literature this work contributes to (section 3.2) from which the theory of change is derived. Then the background information regarding refugees and their hosts in Uganda as well as the conflict in the Democratic Republic of the Congo are explained (section 3.3). Following, the chapter describes the identification strategy, model, and data before presenting the findings (section 3.4). The final part concludes.

\section{$3.2 \quad$ Theory}

Most literature about refugee crises focuses on the displaced persons themselves, while the perspective of the population living close to the settlements remains largely under-researched. Yet, a large increase in population can be expected to impact the local economy, specifically if the receiving country is a developing one which might have difficulties providing for its own population. As Kibreab (1985) describes, in a complex chain of events a refugee situation will first affect the displaced population and then spread to the country of asylum, the country of origin and, lastly, the international community. He states that, giving them the right support in terms of land, agricultural inputs, and access to markets, refugees will be a stimulus of economic growth and development rather than a burden. As described above, the purpose of this work is to analyse in how far the Congolese refugees impact the Ugandan population given the unique legal framework of the country.

The impact on a household's consumption is a priori unclear. Possible risks include disease outbreaks, food and land scarcity, unsafe drinking water, and wage competition (Baez 2011). In 
a macro level study Salehyan and Gleditsch (2006) find that civil war in one country significantly increases the likelihood of conflict for its neighbours. They specifically stress the importance of refugee flows that on the one hand might extend the network of the rebels and on the other hand might be a humanitarian burden, with negative effects on economic conditions and demographic structures in receiving countries. Kirui and Mwaruvie (2012) also stress the security threats that the Dadaab refugee camp and the porous Somalian border pose to North-Eastern Kenya while Montalvo and Reynal-Querol (2007) report an increased occurrence of Malaria.

In contrast, external funding and additional human resources could raise the welfare of the host community and stimulate their local economies through higher demand and the influx of resources from international humanitarian assistance (Baez 2011). Jacobsen (1996, 2002) focuses on factors determining the policy chosen concerning refugees and stresses the potential benefits of economically active refugees and additional development funding.

In the seminal theoretical paper moving to the micro level, Chambers (1986) finds that net sellers of agricultural products will benefit from increased food demand at the cost of net buyers, while land abundance can mean that more land is used benefiting everyone. He argues that ignoring especially vulnerable groups of the host population is fatal as they have needs similar to those of the refugees but cannot use the 'safety net' of a camp. Many empirical works have directly or indirectly built on these thoughts. In a case study about Burundian, Rwandan, and Congolese refugees in Western Tanzania, Whitaker (2002) finds that a number of these general hypotheses hold, e.g., an increase in trade and business, positive effects of relief operations but also altered social dynamics and new diseases. Overall, households and districts that were already better off tended to benefit while others were further marginalised. In the same context, Berry (2008) describes how a bigger cheap labour force and more trade benefited the economy. Agblorti (2011) finds that refugee-hosting areas in Ghana undergo a massive structural change as a small agricultural settlement became a growing urban settlement attracting even Ghanaians to move there.

This qualitative and descriptive literature has only very recently been complemented by quantitative empirical works. ${ }^{33}$ Ten years after the influx of Rwandan and Burundian refugees into Tanzania and eight years after their repatriation, Maystadt and Verwimp (2014) conclude that the overall effect of refugees on the host population's welfare as measured by consumption is positive. Yet, this conceals winners and losers determined by the access to resources, education, or power. In a follow-up study looking at the year 2010 (i.e., 14 years after the departure of the

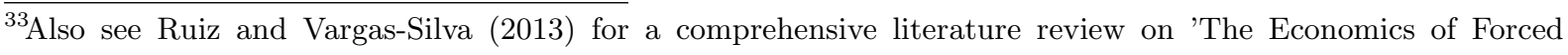
Migration'.
} 
refugees), Duranton and Maystadt (2013) find that the effect has even increased and relate this to the improved road network in the area. Alix-Garcia and Saah (2009) studied the same setting but looked at a shorter time horizon (four years after the influx), documenting large positive price effects of non-aid food items and more modest price effects for aid-related food items as the effect is mitigated through external supplies. When differentiating, they, too, display that the welfare effects at the household level depend on whether they are net sellers (rural population) or net buyers (urban population) of agricultural goods.

For the Ugandan context, Dryden-Peterson and Hovil (2004) argue that, where the lack of coordination between refugee assistance structures and the wider district development structures is resolved, refugees have the potential to benefit commerce as traders and customers. On a similar note, Kaiser (2000) describes that in Uganda's Kibanda district, an estimated 40 per cent of the assistance provided by UNHCR was directed to the area surrounding the refugee settlement at Kiryandongo, again pointing towards a positive impact of refugee presence on households' consumption.

At the community level, effects foreseen by the literature are clearer: The general notion that school and health care facilities might be overburdened by the influx while international funding can lead to more and improved infrastructure (Baez 2011) is differentiated by Chambers (1986), stating that public services and common property resources will be strained in the short run but can benefit in the long term as external aid creates additional supply. For Uganda specifically, Dryden-Peterson and Hovil (2004) describe how public infrastructure provision for nationals is enhanced where hosts are allowed to access refugee schools.

Apart from these objective outcomes, the perceptions of the population are crucial. Jacobsen (2001), for example, determines three main obstacles to local integration: real and perceived security threats, economic and environmental resource burdens (perceived or actual) as well as resistance to integration and pressure on authorities to segregate refugees. In Western Tanzania, Berry (2008) identifies conflicts caused by environmental degradation, while in Ghana hosts generally accepted social and economic integration of Liberians, but were reluctant to political inclusion as well as mingling with their families. Refugees tend to be scapegoats for social ills since they are easily attacked and often unable to defend themselves (Salehyan and Gleditsch 2006) so that, whatever the objective effect of refugee influxes, they are often perceived to be a burden by the host population (Sorenson 1994).

In Uganda, Dryden-Peterson and Hovil (2004) describe the perceived injustice from the part of the local populations in Uganda witnessing trucks of the World Food Programme (WFP) 
entering the settlements. The Ugandan government as well as the UNHCR and its implementing partners stress the necessity of including the national population into the budgeting and planning of service provision in order to avoid conflicts. Notably, contradicting perceptions exist between the local population who see a strain on existing resources and services by the refugees and government officials and aid agencies who report that infrastructure such as health centres would not exist in the absence of refugees and that the new institutions provide a much higher quality of services than generally available in rural Uganda (International Organization for Migration 2013).

This study then contributes to the growing body of quantitative microeconometric literature in a number of ways: While the Tanzanian studies are ex post, the crisis in Uganda is still ongoing, so that looking at this context offers the opportunity to distinguish long-term effects of refugee presence from short-term additional inflows after shocks in the sending country. To our knowledge and also according to Ruiz and Vargas-Silva (2013), this is thus the first study focussing on the effects of a prolonged refugee presence. Additionally, so far the studies were rather descriptive in taking the presence of refugees as given and analysing their effect on markets or on welfare through market mechanisms. In contrast, I carry out a policy analysis less of the impact on the market but rather on the success of the Ugandan state to mitigate it. Tanzania and Uganda are interestingly distinct in their path of political reforms regarding refugees' rights and status: While both have a long history of hosting refugees, Tanzania initially encouraged the Burundians fleeing their home in 1972 to integrate and to become economically self-sustainable, but facing the inflow in 1993/4 restricted their freedom of movement to a $4 \mathrm{~km}$ radius around the camp. As mentioned above and described in more detail in section 3.3, the Ugandan government decided to take the opposite route and to significantly increase the refugees' possibilities to settle and work where they wish to do so. Hence, the impact of refugees in Uganda is likely to be more pronounced and lasting than the short-term, isolated shock in Tanzania. Finally, the host population's perceptions have not yet been considered in a quantitative study.

\subsection{Refugees in Uganda}

Uganda is situated in central eastern Africa with the Democratic Republic of Congo (DRC), Rwanda, and Sudan among its neighbouring countries. Hence, it is in the centre of a region that has seen many internal and internationalised civil wars and a vast extent of destruction and human suffering over the last half century. Most of the more than 190,000 refugees in Uganda come from neighbouring countries, including Burundi, the DRC, Kenya, Rwanda and Sudan (United Nations High Commissioner for Refugees 2013). 
Uganda has traditionally hosted refugees in settlement structures rather than camps, i.e., in large villages in isolated rural areas. In 1999, the Ugandan government passed the so-called self-reliance strategy (SRS), which initially aimed at Sudanese refugees in the West Nile Region but has been extended to the whole country. It is supposed to move refugee support from relief to development. When they arrive, they receive a set of non-food items, a plot of land as well as seeds and food rations for two to four seasons until they are supposed to be self-reliant, i.e., economically independent from food aid. In 2004, the SRS was replaced with the Development Assistance for Refugee-Hosting Areas (DAR) programme which, however, kept the initial focus of the SRS (Clark 2008). Following this was the Refugee Act from 2006/9 that was regarded as a model for Africa, recognising the right of the country's refugees to work, move around the country and live in the community, rather than in special areas. However, if they wish to benefit from UNHCR assistance, they are still bound to the settlements which tend to be located in remote and marginal areas, where access to markets can be difficult. Self-settled refugees in urban areas are not eligible for support (Kaiser 2006). The Act introduced steps towards locally integrating the displaced, e.g., through shared use of hospitals and schools in order to resolve inefficient parallel systems. Notably, in many cases services provided to refugees were of better quality than the local ones, hence the surrounding populations are likely to have benefited from the refugee presence in cases where they could tap newly established social services. In the case of all three laws - SRS, DAR, and the Refugee Act - implementation of the laws has been recorded to be slow and unstructured (see inter alia Dryden-Peterson and Hovil 2004; Garimoi Orach 2005; Rowley et al. 2006).

While in general, refugees and nationals live together peacefully and interact economically and socially, the main source of conflict between them appears to be resources, specifically land. When the first refugees arrived in the 1960s and then again in the early 1990s, both populations were rather small, so giving the displaced persons means for agricultural activities was even considered to be a measure to cultivate underutilised land (Jacobsen 2001). However, in the meantime both groups have grown and land has become a scarce resource with refugees complaining about the size and quality of their plots and hosts accusing them of encroaching on their fields (personal interviews with refugees and aid agency representatives 2014).

The group of refugees under observation in this work originate from the DRC, a state that has been divided by a violent conflict which was sparked by the Rwandan civil war and genocide. The Second Congo War began in 1998 after a coup led by Laurent Kabila took place against long-term dictator Joseph Mobutu and officially ended in July 2003. During these five years, an estimated 3.5 million people were killed, either as a direct result of the fighting or from 
Figure 3.1: UNHCR Presence in Uganda as of July 2012 (Note: Rwamwanja settlement was only opened in 2012; Source: UNHCR website, accessed April 2nd, 2014)

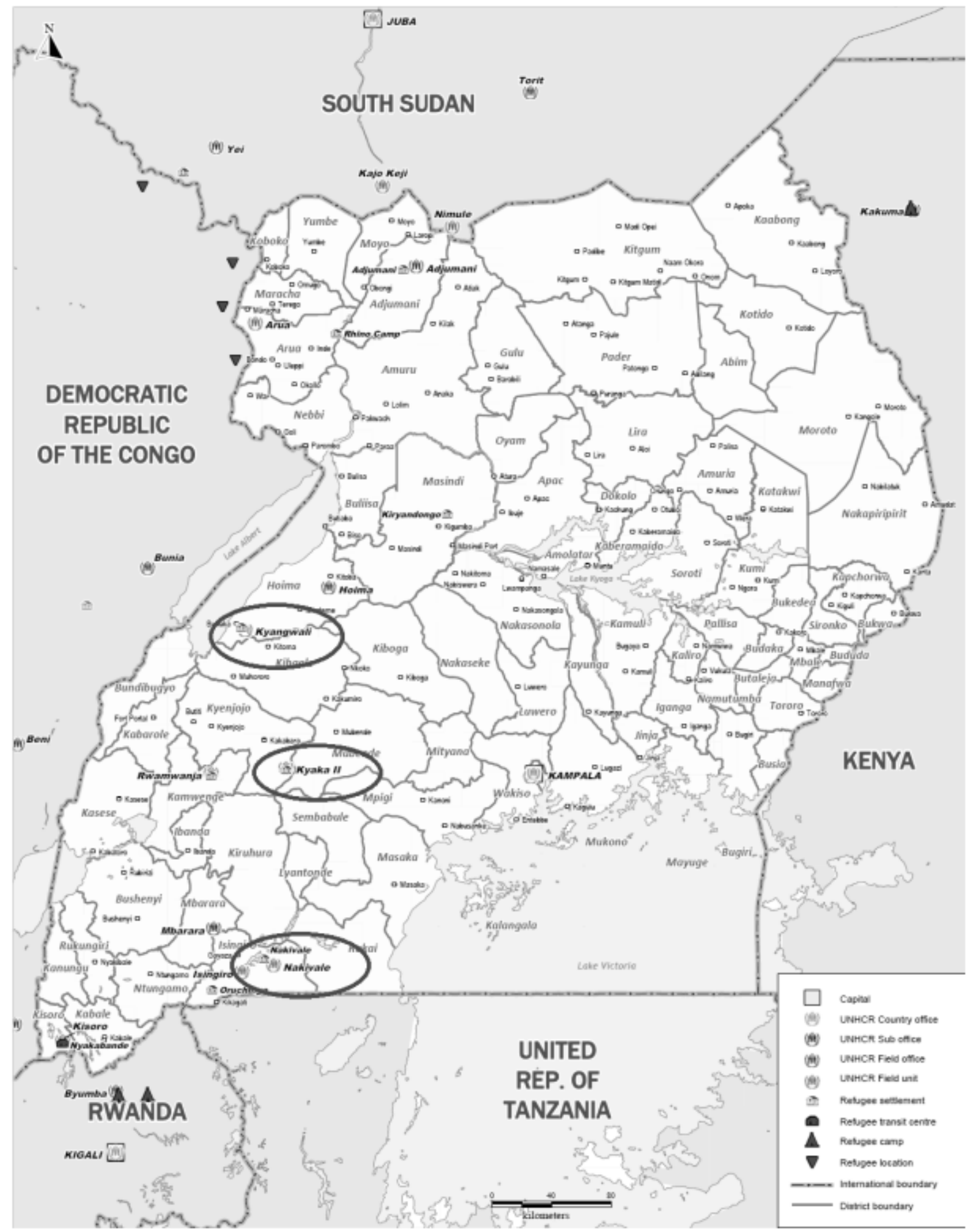


starvation and disease, and an additional 3.6 million people were displaced. Up to nine African states and about 25 armed groups were involved. Although the conflict was initially fought along ethnic lines, there are clear economic interests at work as well, since the DRC is rich in a number of natural resources such as gold, diamonds, timber, and coltan. Still, despite the peace settlement, the situation is highly fragile since many areas remain under the control of rebel forces. While the conflict appeared to calm down after 2003, two major waves of influx of Congolese into Uganda can be noted: In 2005/6 they were sent especially to Kyaka II (Kyenjojo district, Central Region), and in 2008 mainly to Nakivale and Kyangwali (Isingiro and Hoima districts, both Western Region). These inflows are clearly visible in the numbers presented in Table 3.1, both in absolute terms and relative to the district population. The three settlements' locations can be seen in Figure 3.1.

Table 3.1: Absolute and relative number of refugees, 2002-2010

\begin{tabular}{cccccccccc}
\hline \hline & 2002 & 2003 & 2004 & 2005 & 2006 & 2007 & 2008 & 2009 & 2010 \\
\hline Kyangwali & 16,220 & 17,220 & 17,000 & 18,090 & 19,100 & 20,109 & 12,957 & 20,000 & 22,230 \\
& 47.20 & 47.78 & 45.06 & 45.91 & 46.31 & 46.58 & 28.68 & 42.30 & 44.54 \\
\hline Kyaka 2 & 3,159 & 6,180 & 8,780 & 14,600 & 16,415 & 18,229 & 20,033 & 19,132 & 18,230 \\
& 8.38 & 15.79 & 21.64 & 34.77 & 37.72 & 40.41 & 42.86 & 39.49 & 36.12 \\
\hline Nakivale & 14,770 & 14,729 & 15,800 & 15,680 & 21,000 & 33,176 & 38,822 & 50,000 & 56,067 \\
& 61.29 & 60.04 & 58.77 & 55.64 & 67.99 & 98.47 & 111.02 & 135.39 & 144.95 \\
\hline \hline
\end{tabular}

Source: Numbers collected from reports by UNHCR and the Refugee Law Project. The upper row presents the refugee population in a settlement, the bottom row divides this number by district population in 1000s.

Kyangwali is the oldest refugee settlement in Uganda. The land was first home to the displaced from the conflict in Rwanda beginning in 1960. After the majority of these repatriated in the early 1990s, the camp was vacant until 1997 when the crisis in eastern DRC flared up. Now, it is mainly home to Congolese refugees, whose number is fluctuating between about 16,000 and 22,000 over the period under observation. ${ }^{34}$ Kyangwali is known for its inhabitants' relatively high degree of economic self-reliance (Werker 2002, personal interviews with government representatives 2014). Furthermore, integration of infrastructure has been carried out to the degree that health centres and primary schools in the settlement are equally accessible to refugees and the host community (Refugee Law Project 2008).

Nakivale is the second oldest and largest refugee settlement in Uganda. Founded in the early 1960s to accommodate Rwandans fleeing from the unrests, the Nakivale settlement kept its Rwandan character for a long time: In 2003, of the 14,729 refugees living there, 12,311 were

\footnotetext{
${ }^{34}$ These numbers and the ones to follow are estimates collected from reports by the UNHCR, the Refugee Law Project and others.
} 
Rwandans and only 1,154 Congolese. But in 2008, the total number had risen to 38,822, among which there still were 12,632 Rwandans but now also 14,400 Congolese. The host community has been allowed to access the oldest primary school in the area which for a long time was the only one in the county. The 'critical mass' of Ugandan pupils allows the school to keep running even when the number of refugee children fluctuates (downwards) (Dryden-Peterson and Hovil 2003).

Kyaka II has developed in a way similar to Nakivale in the last decade: The number of its population rose from 3,159 in 2002 to about 20,000 in 2008, the increase also stemming mainly from Congolese refugees, about 17,000 of which lived there in 2008. Here as well, hosts can access primary schools initially built by UNHCR and its implementing partners (Dryden-Peterson and Hovil 2004).

UNHCR and its partner organisations carried out an HIV Behavioural Surveillance Survey (BSS) for the refugees in Kyaka II and surrounding communities in 2010 which gives an impression of the composition of both groups as well as the extent of their social and economic interaction (United Nations High Commissioner for Refugees and Intergovernmental Authority on Development 2010). First, it can be noted that the groups are very similar in many regards: They both are by majority Christian, half of which are Catholic and Protestant, respectively. 95 per cent of both groups have only completed primary education at most (refugees do have a larger share of those who never attended school, though). While in both groups the majority of people interviewed depends on agriculture as their main source of income (70 per cent of the refugees vs. 57 per cent of the Ugandans), the share of those active in pastoralism, trading, and crafts is higher among Ugandans. This is not surprising as refugees get their start-up aid in the form of land while the other employment types require a more long-term perspective as well as larger initial investments. Around Kyaka II, it appears that the inward mobility of Ugandans visiting the settlement is larger than outward mobility of refugees travelling to surrounding areas (21 vs. 6 per cent do so 'many times a month' while 66 vs. 73 per cent 'never' do so or 'less than once a month'). The main reason for Ugandans entering the settlement is indeed the infrastructure provided: They use the market for shopping and benefit from the health care. Refugees have less dominant reasons, they more or less equally go for employment, trade, health care, schools or visiting relatives. A small tendency of getting food or visiting the local market being more important than other reasons can be seen. Summarising the findings, it can be said that the two groups are quite similar and that it appears that the local population uses the opportunity to interact more frequently than the refugees which is probably due to the increase in infrastructure for the former who live in remote areas but also to movement restrictions and aid provided to 
the latter.

\subsection{Data and Analysis}

This work is based on two distinct surveys: the Uganda National Household Survey (UNHS) as well as the Afrobarometer Uganda, both carried out in the three waves of 2002/3, 2005/6 and 2009/10 (Ugandan Bureau of Statistics 2010; Afrobarometer 2010). The Afrobarometer creates national probability samples of the populations at voting age (i.e., at least 18 years old), randomly selecting at each stage and interviewing at the household level. It includes 3,777 households in total. ${ }^{35}$ The UNHS also follows a stratified probability proportional to size approach. It includes information at the individual level, however, here only household heads have been kept in the sample as the variables of interest are captured at the household level. The sample consists of 10,833 households in total. ${ }^{36}$

Descriptive statistics of both datasets are displayed in Tables 3.2 and 3.3, organised by refugeehosting and non-hosting areas. ${ }^{37}$ There are 32 districts overall, three of which host refugee settlements. ${ }^{38}$ Kampala has been excluded as it is the main urban centre of the country and thus very different from other districts. Furthermore, it hosts many unofficial refugees that cannot be accounted for.

The unconditional comparison indicates that, while households are similar in terms of size, source of income, education as well as gender and age structure, there appear to be differences with regard to the explaining factors of interest; i.e., refugee presence, violent events, and distance to the DRC and Rwandan border. In line with the reasoning above, refugee-hosting districts are closer to the borders and further away from Kampala while suffering from higher numbers of violent events. From Tables 3.2 and 3.3, it would also appear that the presence of refugees is associated with lower consumption, lower education, and lower economic activity as proxied by the night-time light. This is an observation underlining the importance of proper econometric analysis as the results below will not confirm this impression.

This analysis encompasses three fields of possible impacts: First, household level welfare measured by a consumption aggregate calculated by the Ugandan Bureau of Statistics (UBOS). It encompasses monthly household consumption expenditure per adult equivalent. Second, public

\footnotetext{
${ }^{35}$ Specifically, there are 1,113 households in the year 2002/3, 949 in 2005/6 and 1,715 in 2009/10.

${ }^{36}$ Specifically, the UNHS captures 4,822 households in the year 2002/3, 3,366 in 2005/6, and 2,645 in 2009/10.

${ }^{37}$ These are districts comprising refugee settlements. Self-settled refugees cannot be accounted for as they are not registered.

${ }^{38}$ In order to disentangle external effects from conflicts abroad in the form of international refugees from economic hardships caused by fighting during the civil war and internally displaced persons (IDPs), this work focuses on the relatively peaceful Southern and Western parts of Uganda. The Ugandan civil war took place approximately from 1987 to 2005, then the fighting moved abroad to the DRC and the Central African Republic. The South-West is also the bordering region with the DRC and Rwanda and the refugees' point of entry, thus their share relative to the local population is especially high.
} 
Table 3.2: Descriptive Statistics UNHS, at the Household and Community Level

\begin{tabular}{|c|c|c|c|c|c|c|c|}
\hline & \multicolumn{3}{|c|}{ Non-hosting areas } & \multicolumn{3}{|c|}{ Refugee-hosting areas } & \multirow[t]{2}{*}{ t-statistic } \\
\hline & Mean & $\mathrm{SD}$ & $\mathrm{N}$ & Mean & SD & $\mathrm{N}$ & \\
\hline \multicolumn{8}{|l|}{ Household level } \\
\hline Consumption & 59115.18 & 104971.34 & 10017 & 46495.88 & 43963.89 & 814 & $3.41^{* * *}$ \\
\hline Age & 39.96 & 14.54 & 10019 & 40.08 & 14.60 & 814 & -0.22 \\
\hline Male & 0.72 & 0.45 & 10019 & 0.78 & 0.42 & 814 & $-3.28^{* *}$ \\
\hline Household members & 5.13 & 3.06 & 10019 & 5.34 & 2.93 & 814 & -0.214 \\
\hline Highest grade & 6.45 & 5.40 & 9863 & 5.72 & 5.16 & 811 & $3.73^{* * *}$ \\
\hline \multicolumn{8}{|l|}{ Main source of income } \\
\hline Wage & 0.23 & 0.42 & 9958 & 0.22 & 0.42 & 811 & 0.22 \\
\hline Self-employed & 0.30 & 0.46 & 9958 & 0.21 & 0.41 & 811 & $5.14^{* * *}$ \\
\hline Property & 0.01 & 0.09 & 9958 & 0.01 & 0.09 & 811 & -0.06 \\
\hline Transfers & 0.05 & 0.22 & 9958 & 0.05 & 0.22 & 811 & -0.06 \\
\hline Agriculture & 0.42 & 0.49 & 9958 & 0.50 & 0.50 & 811 & $-4.9^{* * *}$ \\
\hline \multicolumn{8}{|l|}{ Community level } \\
\hline Refugees per 1,000 & 0.00 & 0.00 & 1046 & 48.94 & 32.84 & 84 & $-48.44^{* * *}$ \\
\hline Urban & 0.26 & 0.44 & 1046 & 0.18 & 0.39 & 84 & 1.70 \\
\hline Population in 1,000 & 388822.46 & 240407.10 & 1046 & 398103.48 & 61825.44 & 84 & -0.35 \\
\hline Distance border & 124.16 & 85.54 & 1046 & 52.17 & 19.50 & 84 & $7.69^{* * *}$ \\
\hline Violent events & 0.33 & 0.68 & 1046 & 0.66 & 0.81 & 84 & $-4.20^{* * *}$ \\
\hline Night-time light $(* 1,000,000)$ & 0.60 & 1.08 & 1046 & 0.07 & 0.08 & 84 & $4.53^{* * *}$ \\
\hline \multicolumn{8}{|l|}{ Public services available } \\
\hline Gov. primary school & 0.39 & 0.49 & 1040 & 0.33 & 0.47 & 84 & 1.00 \\
\hline Priv. primary school & 0.35 & 0.48 & 917 & 0.30 & 0.46 & 73 & 0.88 \\
\hline Gov. health unit & 0.09 & 0.28 & 1042 & 0.08 & 0.28 & 84 & 0.15 \\
\hline Priv. health unit & 0.34 & 0.47 & 1003 & 0.26 & 0.44 & 77 & 1.49 \\
\hline
\end{tabular}

Column 7 shows the t-statistic for the t-test of equal means between the groups.

Table 3.3: Descriptive Statistics Afrobarometer, at the Household Level

\begin{tabular}{lccccccc}
\hline \hline & \multicolumn{3}{c}{ Non-hosting areas } & \multicolumn{3}{c}{ Refugee-hosting areas } & \multicolumn{2}{c}{ t-statistic } \\
& Mean & SD & N & Mean & SD & N \\
\hline Living conditions & 0.39 & 0.49 & 3106 & 0.43 & 0.50 & 658 & -1.78 \\
Ethnic rather than national identity & 0.24 & 0.43 & 3005 & 0.22 & 0.42 & 623 & 0.84 \\
Age & 33.46 & 12.33 & 3118 & 33.92 & 12.42 & 659 & -0.86 \\
Male & 0.50 & 0.50 & 3118 & 0.50 & 0.50 & 659 & -0.02 \\
Highest grade & 3.21 & 1.79 & 3113 & 3.33 & 1.75 & 658 & -1.54 \\
Gone w/o food & 0.76 & 1.01 & 3114 & 0.59 & 0.98 & 653 & $4.06^{* * *}$ \\
Gone w/o water & 1.02 & 1.26 & 3115 & 1.20 & 1.39 & 657 & $-3.35^{* * *}$ \\
Gone w/o medical care & 1.36 & 1.20 & 3113 & 1.33 & 1.20 & 656 & 0.72 \\
Radio news & 3.46 & 1.07 & 3116 & 3.56 & 1.00 & 658 & $-2.13^{*}$ \\
Refugees per 1,000 & 0.00 & 0.00 & 3118 & 32.06 & 13.02 & 659 & $-137.59^{* * *}$ \\
Night-time light $(* 1,000,000)$ & 0.00 & 0.00 & 3118 & 0.00 & 0.00 & 659 & $13.05^{* * *}$ \\
Urban & 0.15 & 0.35 & 3118 & 0.15 & 0.35 & 659 & 0.12 \\
Population in 1,000 & 440788.00 & 266915.13 & 3118 & 921088.53 & 401771.84 & 659 & $-37.99^{* * *}$ \\
Distance border & 116.60 & 86.93 & 3118 & 60.68 & 7.99 & 659 & $16.50^{* * *}$ \\
Violent events & 0.38 & 0.78 & 3118 & 0.49 & 0.73 & 659 & $-3.25^{* *}$ \\
\hline \hline
\end{tabular}

Notes: ${ }^{*} p<0.05,{ }^{* *} p<0.01,{ }^{* * *} p<0.001$

Column 7 shows the t-statistic for the t-test of equal means between the groups. 
good provision, specifically health and education as these are among the most basic services that a state provides. They are captured at the community level through the question: 'Is there a [education/ health facility] present in this community?' Although these indicators make a statement on the existence of rather than the effective access to a service, they are still meaningful indicators here. While a positive effect of the presence of refugees would indicate the building of new facilities, a negative impact would imply the diversion of scarce resources away from refugee localities in reliance on the international aid community or within the refugee localities away from service provision to nationals to providing for displaced people. Third, households' subjective well-being is analysed, reported as the answer to: 'In general, how would you describe: Your own present living conditions?' as well as 'Let us suppose that you had to choose between being a Ugandan and being a _ (Ethnic Group). Which of the following best expresses your feelings?' In the first case, the variable takes a value of one for 'Neither good nor bad', 'Fairly good' or 'Very good' rather than 0 which represents 'Very bad' or 'Fairly bad'. In the second case, the variable is 1 if 'I feel only Ugandan' or 'I feel more Ugandan than (ethnic group)' as opposed to 0 which stands for 'I feel only (ethnic group)', 'I feel more (ethnic group) than Ugandan' or 'I feel equally Ugandan and (ethnic group).' The motivation for analysing whether a person feels more belonging to their nationality or their ethnicity is based on the idea that perceived identity also depends on the context the person finds themselves in (e.g., Hadnes and Roggemann 2014) and might be used as a means of differentiation. That is, Ugandans and refugees have a similar ethnic background and, depending on the degree to which the Ugandans sympathise with or feel the need to discriminate against the refugees, either one identity could become more important.

The main variables of interest then capture the long-term level of refugee presence as well as the shocks between the respective survey waves (also see the section on identification). The number of refugees per 1,000 inhabitants is used as an indicator for host country capacity, following the UNHCR. ${ }^{39}$ In the first analysis, the levels themselves are applied. This is the most straightforward measure of refugee pressure and follows the long-term trend. Yet, it does not consider spikes in refugee numbers between two survey years such as the emergencies in 2006 and in 2008 which might better explain outcomes malleable in the short run. In order to do so, further specifications simultaneously account for this shock, too. The shock is first represented by a variable capturing the maximum increase in refugees over local population from one year to another (between survey waves), divided by the distance to the next settlement. The latter transformation has the advantage that it does not only vary at the district but at the sub-county

\footnotetext{
${ }^{39}$ Both the number of refugees and the district population vary over time. Population size is included as a control variable in all specifications in order to capture population changes.
} 
level, thus increasing variation and allowing for the inclusion of district fixed effects (see below). Extreme increases in refugee population are deemed a strain on local infrastructure and a possible trigger of public resentment. ${ }^{40}$

Based on the general conflict literature, a binary distance measure is adopted as an instrument for intensity, too (see inter alia Akresh and De Walque 2008; Miguel and Roland 2011; Serneels and Verpoorten 2012; Voors et al. 2012). It takes the value 1 if the household or community are situated within a $60 \mathrm{~km}$ radius of the settlement and 0 otherwise.

There is a difference between district level treatments and distance that should be kept in mind: While policy decisions are made at the district level, distance also accounts for communities that border respective districts - who might suffer when refugees leave the settlement and just go to the closest school (or hospital or market) rather than the district one, without the hosts getting the same kind of compensation.

Furthermore, control variables are added for the individual level, explaining the household's ability to make a living as well as their attitudes. Namely, I include age, sex, the highest grade of schooling completed, and dummies for the main income source (wage, self-employment, property, transfers or subsistence agriculture). In line with the literature, I also add the squared term of age, as an inverted U shaped relationship between age and both income (or consumption) and life satisfaction has been found (e.g., Dolan et al. 2008, Lohmann 2015 and van Biesebroeck 2010). In addition, community (rural/ urban), and district characteristics are included such as violent events (Report data from ACLED: Raleigh et al. 2010) and night-time light as a proxy for regional development (NOAA National Geophysical Data Center and US Air Force Weather Agency 2011). In general, the situation in Uganda's South and South-West was peaceful in the period under observation. The activities of the Lord's Resistance Army (LRA) were concentrated in the North of the country and moved into Southern Sudan and the DRC from 2006 onwards. The activities of the Allied Democratic Forces (ADF) peaked between 1997 and 2001, while by 2002, they had calmed down (De Luca and Verpoorten 2011). In line with this, there are very few event days per year on average recorded, which are not focussed on specific areas of the country. Regarding GDP p.c., one might assume that the more straightforward measure would be the average per capita consumption as measured by the survey. However, this measure would not be available for the Afrobarometer. In addition, while including district fixed effects,

\footnotetext{
${ }^{40}$ Of course, extreme reductions in the refugee population can decrease overall population to a degree that makes running services uneconomical which would also threaten the host population's access to those services. However, this phenomenon is not the focus of this paper. At the same time, inflows are more likely to be exogenous to the dependent variables, while outflows of refugees - both to other areas of the host country or back to their country of origin - are likely to depend on the living conditions within the settlement.
} 
it would be a very close predictor of household consumption and overlay the effect of other variables. Thus, in order to ensure comparability between all specifications, the light data is used as a proxy. As mentioned above, refugees might just be sent to sparsely inhibited areas as well as those ones close to the border with the conflict region. Thus, both the district population (Ugandan Bureau of Statistics 2011) and the shortest sub-county distance to either the DRC or Rwanda (author's calculation) are controlled for.

\subsubsection{Identification}

As there are two time horizons applied to this analysis, both must be considered separately in terms of identification. The identification of the effects of the sudden inflow of refugees rests on the unexpected size and nature of the refugee influxes, generating a natural experiment. Although all three settlements under observation already existed when these shocks occurred, so that a certain degree of adaptation by the local infrastructure and the population is likely to have had taken place, especially Nakivali and Kyaka II massively increased in size which will have affected the surrounding communities. Figure 3.2 displays the absolute number of refugees arriving each year between 1990 and 2011. As can be seen, the numbers are very close to zero throughout the 1990s and the peaks in inflows described above are clearly visible.

Figure 3.2: Number of newly arriving refugees by settlement, 1990-2011

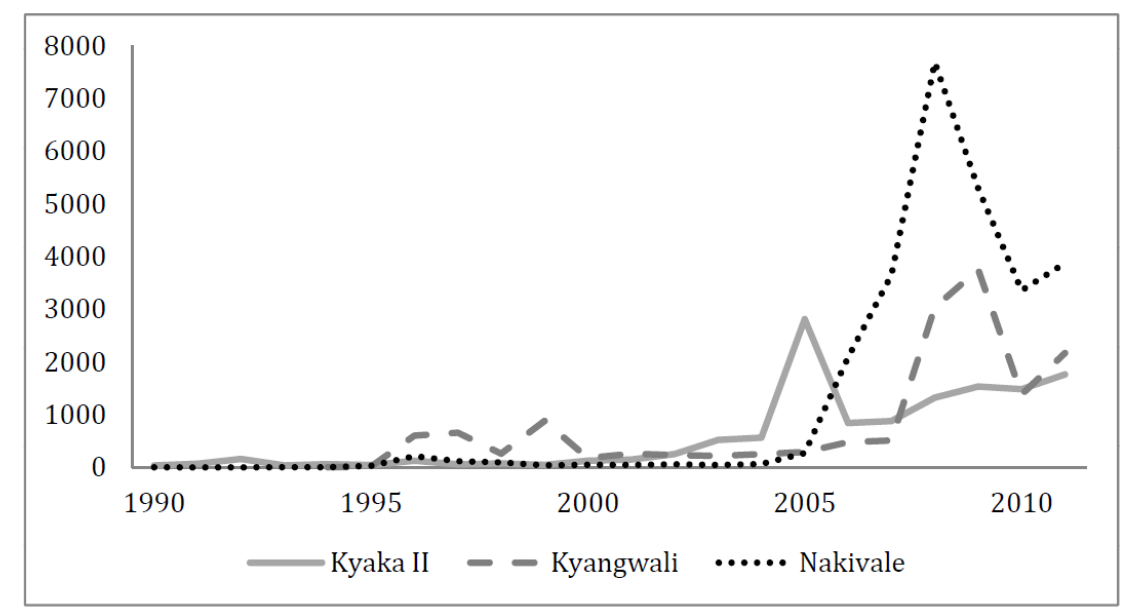

The earliest available wave of the UNHS is from the year 1992.41 As this is 'in between' the two periods of activity of the refugee settlements (i.e., the 1960s and the 2000s), this data can help to test if refugee-hosting districts differed from those without a refugee settlement (see Table 3.4). ${ }^{42}$ As can be seen, the two groups appear to be very similar, they do not differ

\footnotetext{
${ }^{41}$ However, no detailed information on the size of the refugee settlements is available so that the analysis cannot be extended to the waves of 1992, 1995, and 1999.

${ }^{42}$ The current number of districts (32) is the result of multiple partitions in the course of the 1990s. In 1992, there were merely 18 districts, thus the small number of observations in Table 3.4.
} 
Table 3.4: District Characteristics in 1992, at the Household Level, Including t-Test

\begin{tabular}{|c|c|c|c|}
\hline & $\begin{array}{c}\text { Non-hosting areas } \\
\text { Mean }\end{array}$ & $\begin{array}{c}\text { Refugee-hosting areas } \\
\text { Mean }\end{array}$ & t-statistic \\
\hline Age & 39.49 & 38.33 & 1.02 \\
\hline Male & 0.73 & 0.74 & -0.26 \\
\hline Household members & 4.51 & 4.38 & 0.50 \\
\hline Highest grade & 5.91 & 6.53 & -0.95 \\
\hline Av. welfare in district & 25331.46 & 28888.64 & -1.27 \\
\hline Urban & 0.30 & 0.42 & -1.63 \\
\hline Population in 1,000 & 5206941.87 & 6548489.33 & -0.59 \\
\hline Distance border & 107.28 & 56.32 & 0.98 \\
\hline \multicolumn{4}{|l|}{ Main source of income: } \\
\hline Wage & 0.25 & 0.27 & -0.41 \\
\hline Self-employed & 0.14 & 0.18 & -1.31 \\
\hline Property & 0.00 & 0.01 & -1.51 \\
\hline Transfers & 0.00 & 0.00 & -0.52 \\
\hline Agriculture & 0.57 & 0.48 & 1.20 \\
\hline \multicolumn{4}{|l|}{ Public service available: } \\
\hline Primary school & 0.34 & 0.35 & -0.09 \\
\hline Gov. health unit & 0.12 & 0.09 & 0.34 \\
\hline Priv. health unit & 0.14 & 0.02 & 1.48 \\
\hline
\end{tabular}

significantly in any of the characteristics (see the t-statistics of the two-group mean-comparison test). In addition, when following Sribney (1996) with his suggested test for a common trend of the dependent variables under analysis before 2010, in the majority of cases, it is not possible to reject the null hypothesis of a parallel development between hosting and non-hosting regions. ${ }^{43}$

When arriving in one of the transition centres at the borders, refugees do not have a choice concerning their long-term settlement but are allocated according to capacity of the settlements. Whether refugees ended up in a specific area or not can be considered as being random from another perspective as well: The Congolese people entered Uganda rather than another neighbouring country because of movements in their own country which are presumably unrelated to public service provision and welfare in Ugandan districts. While this could be disputable in districts bordering the DRC, considering that Ugandan rebels are also involved in the conflict, this certainly holds for those concerned here as they were initially set up for Rwandan refugees and are thus further away from the Congolese border and do not shelter insurgent groups. ${ }^{44}$

Regarding the long-term presence, camps are likely to have been established in order to facilitate food aid, to be easily accessible by the refugees and to be in areas with unused land. When taking the very simple approach of regressing a binary indicator for refugee presence on district characteristics for the very earliest available data from the year 1992 (see Table 3.5), neither district welfare nor the distance to the border with the DRC appear to be significant in neither

\footnotetext{
${ }^{43}$ Notably, simple pairwise correlation between the outcomes and the group membership are calculated, a logit model with refugee presence as an outcome variable is run, and a nonparametric test for a trend across ordered groups is carried out. Only the availability of government primary schools turns out to be negatively significant in the last case.

${ }^{44}$ Maystadt and Verwimp (2014), Alix-Garcia and Saah (2009), and Baez (2011) follow a similar identification strategy in their analysis of the impact of Rwandan and Burundian refugees on Tanzanian markets.
} 
Table 3.5: Refugee Presence and District Characteristics in 1992

\begin{tabular}{lcc}
\hline \hline & $(1)$ & $(2)$ \\
& OLS & Logit \\
\hline Av. welfare in district & 0.0000003 & -0.00005 \\
& $(0.00003)$ & $(0.0002)$ \\
Urban & 1.2 & 11.1 \\
& $(0.9)$ & $(7.9)$ \\
Population in 1,000 & 0.00000003 & 0.0000004 \\
& $(0.00000004)$ & $(0.0000005)$ \\
Distance border & -0.001 & -0.01 \\
Constant & $(0.001)$ & $(0.02)$ \\
& -0.3 & -5.6 \\
& $(0.6)$ & $(5.0)$ \\
\hline Observations & 18 & 18 \\
\hline
\end{tabular}

Standard errors in parentheses

The dependent variable is a binary variable indicating whether the district will host refugees in future.

${ }^{*} p<0.10,{ }^{* *} p<0.05,{ }^{* * *} p<0.01$

the ordinary least squares (OLS) nor the Poisson specification. The analysis nevertheless controls for these factors and takes advantage of variation in the number of refugees over time. Additionally, district-specific factors that are constant over time are captured in fixed effects.

In most specifications, the analysis will take into account the district level 'refugee intensity' and also district level shocks. ${ }^{45}$ Two factors support the assumption that the effect will be rather confined to the district level: The first one concerns the location of the settlements which are situated in remote rural areas with high transportation costs. That is to say, interaction among refugees and the host population will be confined to a rather small radius. The displaced are only considered for UNHCR support when living in the settlements, so that if they make use of their newly acquired right to work outside the settlement, most will be likely to do so within commuting distance. Second, the political system in Uganda after democratisation has put a lot of weight on decentralisation and allocated the power of decision-making over public policies to the so-called LC5 level, i.e., the districts (Byenkya 2012; Ranis 2012). This means that, for example, negotiations between the UNHCR and the government over the service provision and sharing will take place in a district-specific way.

\subsubsection{Model}

This work exploits two exogenous incidences of refugee influx, using two survey waves collected before and one after their occurrence to calculate a three-period difference-in-differences model. Large refugee inflows (the so-called treatment) are indicated in two different ways, described in detail above. Both datasets consist of three repeated cross-sections which allows to control for a common time trend before the treatment. In general, the equation that includes household and

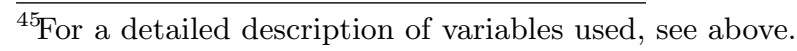


district control variables $\left(X_{i, t}\right.$ and $\left.D_{d, t}\right)$ takes the following form:

$$
y_{i, t}=\beta_{0}+\beta_{1} \text { refugee_level }_{d, t}+\beta_{2} \text { treatment }_{s, t}+\beta_{3} X_{i, t}+\beta_{4} D_{d, t}+\delta_{t}+\delta_{d}+\epsilon_{d, t},
$$

with $y$ being the different outcomes, $i$ indicates the household or community, $s$ the sub-county, $d$ the district, and $t$ the year. Using a pooled cross-section inherently assumes that the impact remains equal over the years. In order to account for differing distributions due to repeated sampling, different intercepts are allowed, i.e., year fixed effects are included $\left(\delta_{t}\right)$. At the same time, district fixed effects are included to control for unobserved heterogeneity $\left(\delta_{d}\right)$. As the units of observation (households, communities) are at a lower level than the unit of the measure for refugee presence (districts), standard errors $\epsilon$ are clustered at the district level. ${ }^{46}$ The coefficients of interest then are $\beta_{1}$ for the long-term impact of refugees on the host population in a specific district and $\beta_{2}$ representing the additional effect of sudden inflows at the sub-county level.

In each case, linear probability models have been given preference over logit or probit ones due to the more straightforward interpretation of coefficients as marginal effects. However, results do not change when applying a nonlinear model, when it is possible.

\subsubsection{Findings}

Results of the impact of refugee inflows on economic welfare of households in the hosting districts are presented in Table 3.6. ${ }^{47}$ Overall, refugee presence appears to increase monthly consumption (column 1), while large positive fluctuations do so even more (column 2), which is line with reports from the field that Ugandans can partly access emergency aid. Hence, it appears that a larger population does benefit those already living in the area, for example by opening up new possibilities to trade and attracting new enterprises. Economically, the effect means that increasing the number of refugees per 1,000 inhabitants by 10 (which is reasonable looking at the data in Table 3.1), would on average increase consumption by 2 per cent. At the average expenditure in refugee-hosting areas of 46,496 Ugandan shillings (UGX), this would be about 935 UGX or 50 US cents, 1.43 US dollars if purchasing power parities are considered. This is roughly equivalent to a day's income.

\footnotetext{
${ }^{46}$ This affects the numbers of observation reported. They represent the households or communities in the survey while the 'real' number of observations has to be based on the sub-counties and districts as these are the levels where the treatments vary. The sample encompasses 32 districts, three of which host refugees as described above, and 379 sub-counties. Hence, a higher number of households makes the estimates more efficient while the model is identified by the variation across districts and sub-counties.

${ }^{47} \mathrm{~A}$ reduced model including only the indicator for refugee levels and fixed effects are presented in the appendix. The results are identical with the full models and thus not shown here for improved manageability. For the same reason, control variables and standard errors have been suppressed in the main tables. Full tables are also included in the appendix.
} 
Table 3.6: Household Consumption by Main Income Source, Linear Probability Models, 2002-2010

\begin{tabular}{|c|c|c|c|}
\hline & \multicolumn{3}{|c|}{ Log(Consumption) } \\
\hline & (1) & $(2)$ & (3) \\
\hline Refugees per 1,000 & $0.003^{* * *}$ & 0.001 & $0.002^{* * *}$ \\
\hline Maximum increase & & $8.4^{* * *}$ & \\
\hline Radius 60 km & & & 0.05 \\
\hline Wage*Refugees per 1,000 & -0.001 & & \\
\hline Self-employed*Refugees per 1,000 & -0.001 & & \\
\hline Property*Refugees per 1,000 & 0.001 & & \\
\hline Transfers*Refugees per 1,000 & $-0.006^{* * *}$ & & \\
\hline Wage*Max. increase & & $-10.1^{* * *}$ & \\
\hline Self-employed*Max. increase & & $-2.4^{*}$ & \\
\hline Property*Max. increase & & -6.8 & \\
\hline Transfers*Max. increase & & $-28.8^{* * *}$ & \\
\hline Wage*Radius $60 \mathrm{~km}$ & & & $-0.1^{* *}$ \\
\hline Self-employed*Radius 60km & & & -0.05 \\
\hline Property*Radius $60 \mathrm{~km}$ & & & -0.06 \\
\hline Transfers*Radius $60 \mathrm{~km}$ & & & $-0.2^{*}$ \\
\hline Wage & $0.1^{* * *}$ & $0.1^{* * *}$ & $0.1^{* * *}$ \\
\hline Self-employed & $0.2^{* * *}$ & $0.2^{* * *}$ & $0.2^{* * *}$ \\
\hline Property & $0.3^{* * *}$ & $0.3^{* * *}$ & $0.3^{* * *}$ \\
\hline Transfers & $0.2^{* * *}$ & $0.1^{* * *}$ & $0.2^{* * *}$ \\
\hline Observations & 10623 & 10623 & 10623 \\
\hline Mean Consumption & 10.64 & 10.64 & 10.64 \\
\hline R Squared & 0.331 & 0.332 & 0.331 \\
\hline
\end{tabular}

Differentiating by income source draws a more nuanced picture. While the overall effect is robust and each group benefits in general, those depending on wage income and transfers appear to face hardships in times of a shock and to be even worse off in the presence of refugees (columns 1 and 2). ${ }^{48}$ This finding holds across different shock measures and is intuitive assuming that refugees are a priori more likely to enter dependent employment and compete with rural landless workers while starting an enterprise or living off property requires higher initial investments.

Regarding the public service provision (Tables 3.7 and 3.8), notably health facilities and schools, there are indications for congestions in the health sector. It appears that public centres are less likely to be accessible when the relative number of refugees increases (columns 1 and 2 of Table 3.7). In the health sector, especially regarding government services, the distinctness of the distance as opposed to the district level measures is visible: While fluctuation in the relative number of refugees in the same district does not appear to be significantly related to the accessibility of clinics (column 3 of Table 3.7), Ugandans living close to the settlements independently of district borders are more likely to report to have access to a government health unit (column 2 of Table 3.7). The effect for private health centres is clearly counter-intuitive. However, when going back to the 1992 characteristics in Table 3.4, one can see that, although not significantly different in the t-test, the availability of private clinics is already higher in

\footnotetext{
${ }^{48}$ The omitted category is subsistence agricultural income which is presumably the most independent from the economic environment.
} 
Table 3.7: Public and Private Health Services in Community, Linear Probability Models, 2002-2010

\begin{tabular}{lccccccc}
\hline & \multicolumn{3}{c}{ Government health unit } & & \multicolumn{3}{c}{ Private health unit } \\
\cline { 2 - 3 } \cline { 7 - 8 } & $(1)$ & $(2)$ & $(3)$ & & $(4)$ & $(5)$ & $(6)$ \\
\hline Refugees per 1,000 & $-0.0008^{* *}$ & $-0.0009^{* * *}$ & -0.001 & $-0.003^{*}$ & $-0.002^{*}$ & -0.002 \\
Maximum increase & & & 0.8 & & & $-2.5^{*}$ \\
Radius 60 km & & $0.08^{* *}$ & & & -0.06 & \\
\hline Observations & 1126 & 1126 & 1126 & 1080 & 1080 & 1080 \\
Mean Provision & 0.0879 & 0.0879 & 0.0879 & & 0.337 & 0.337 & 0.337 \\
R Squared & 0.0559 & 0.0595 & 0.0559 & & 0.178 & 0.178 & 0.178 \\
\hline Control variables as well as year and district fixed effects are included in \\
all specifications. Standard errors are clustered at the district level. \\
${ }^{*} p<0.1,{ }^{* *} p<0.05,{ }^{* * *} p<0.01$
\end{tabular}

non-refugee hosting areas (0.14 vs. 0.02). It thus appears that the divergence has continued due to service provision clustering around Kampala and Lake Victoria (as visible when looking at values by district) and the difference has by now become significant.

With regard to primary schools, privately provided education (e.g., by non-governmental organisations, NGOs) is more common where more refugees live (see Table 3.8, columns 4 to 6). This again is in line with policy expectations as NGOs react to humanitarian crises. There is no significant effect for government schools (columns 1 to 3 of Table 3.8). Taken together, the results indicate that the Ugandan government does not readjust the service provision in the health sector to the increased population. In primary education, outcomes could stem from private providers building new infrastructure and opening it for refugees or from the refugee population making it worthwhile to provide education in sparsely settled areas. Both of these channels are in line with the literature.

Table 3.8: Public and Private Primary Education in Community, Linear Probability Models, 2002-2010

\begin{tabular}{|c|c|c|c|c|c|c|}
\hline & \multicolumn{3}{|c|}{ Government primary school } & \multicolumn{3}{|c|}{ Private primary school } \\
\hline & (1) & $(2)$ & (3) & (4) & $(5)$ & (6) \\
\hline Refugees per 1,000 & 0.0009 & 0.0010 & -0.0002 & $0.006^{* * *}$ & $0.006^{* *}$ & $0.006^{* * *}$ \\
\hline Maximum increase & & & 5.1 & & & 1.9 \\
\hline Radius 60 km & & -0.06 & & & 0.08 & \\
\hline Observations & 1124 & 1124 & 1124 & 990 & 990 & 990 \\
\hline Mean Provision & 0.384 & 0.384 & 0.384 & 0.348 & 0.348 & 0.348 \\
\hline R Squared & 0.0717 & 0.0724 & 0.0725 & 0.185 & 0.186 & 0.185 \\
\hline
\end{tabular}

The magnitude of the effects on private education and public health facilities is notable, as the coefficients estimated represent marginal effects, ergo an increase in 10 refugees over 1,000 inhabitants is correlated with a $\beta$ times 10 percentage points increase in the likelihood of a service being provided in the community. For private primary schooling, this would mean an 
increase of 0.06 percentage points (columns 4 to 6 of Table 3.8), at an average likelihood of a private primary school in a refugee-hosting area of 0.3 which would be around 20 per cent. For public health services, the same example would lead to a decrease of 0.009 percentage points (column 2 of Table 3.7) but at an average likelihood of 0.08 , which is about 11 per cent. Thus, in the health sector, there is an indication towards a deterioration of the availability of state-run services while in the primary education provision, it points towards an increase in private sector service provision.

Table 3.9: Households' Perceptions, Linear Probability Models, 2002-2010

\begin{tabular}{|c|c|c|c|c|c|c|}
\hline & \multicolumn{3}{|c|}{ Living conditions } & \multicolumn{3}{|c|}{ Ethnic rather than national identity } \\
\hline & (1) & $(2)$ & $(3)$ & (4) & $(5)$ & $(6)$ \\
\hline Refugees per 1,000 & $-0.004^{*}$ & $-0.004^{*}$ & $-0.005^{*}$ & $0.007^{* * *}$ & $0.007^{* * *}$ & $0.009^{* * *}$ \\
\hline Maximum increase & & & 2.3 & & & -6.4 \\
\hline Radius $60 \mathrm{~km}$ & & $-0.08^{* * *}$ & & & 0.04 & \\
\hline Observations & 3741 & 3741 & 3741 & 3608 & 3608 & 3608 \\
\hline Mean Perception & 0.400 & 0.400 & 0.400 & 0.233 & 0.233 & 0.233 \\
\hline R Squared & 0.128 & 0.129 & 0.128 & 0.0492 & 0.0493 & 0.0497 \\
\hline
\end{tabular}

Interestingly, when looking at the households' own assessment of their economic situation in Table 3.9, it yields a result contradicting the welfare analysis but in line with qualitative findings of Kaiser (2000) and Dryden-Peterson and Hovil (2004) described above: On average, people feel as though they are worse off in areas with a higher level of refugees (columns 1 to 3), even more so when living close to settlements (column 2). This means that, although actors in the field like NGO or government officials mutually state that the situation of the local population has improved because of the presence of the refugees through increased economic activity and access to infrastructure, the Ugandans themselves do not feel this way. A similar finding was presented by the Ugandan Participatory Poverty Assessment Report (Republic of Uganda 2000) which revealed that despite a decrease in poverty in objective measures (notably consumption), the population in the project districts described their welfare situation as having deteriorated over the same period. ${ }^{49}$ Possibly the positive effects shown in the analysis above are overlain in the perceptions by a sense of competition for resources and threat through the presence of strangers. This impression holds for the feeling of identity (columns 4 to 6). Here, the host population is more inclined to identify with their nationality, i.e., as being Ugandan, rather than with their ethnic background, which they often share with the refugees and could thus

\footnotetext{
${ }^{49}$ The districts included in this analysis, however, were not part of this study. While to our knowledge nobody has analysed the reasons for this contradiction, the results of the poverty assessment might stem from the fact that the seven poorest districts were selected then so that people might have judged their situation relative to the one of districts that were better off.
} 
be a source of sympathy and solidarity. As stated above, the host population is an important stakeholder in the process of local integration and should thus be considered. Unfortunately, the Afrobarometer does not include occupation information for all waves, hence a disaggregated analysis as in the case for welfare is not possible and a more nuanced picture cannot be drawn.

\subsubsection{Discussion and Robustness}

From the findings in section 3.4.3 one can see a rather robust positive effect of refugees on the consumption and private education access of host communities. The effects in the health sector are slightly less stable but indicate a negative impact. Households' perceptions of their own economic situation as well as their feeling towards their national state have also been shown to be negatively affected in different specifications.

Overall, the main effect stems from the level of refugees in survey years, i.e., the steady increase, rather than from the shock variable. This could mean that long-term effects dominate short-term fluctuations. This makes sense considering structures that have already been set up and personnel that is already present. However, the survey only asks about the existence of a public service, it does not make any statement about its quality. It is thus still possible (and likely) that schools and clinics have been built to provide for the long-term population but are overrun by an unexpected influx. Teachers and implementing organisations report that there are up to 150 pupils per classroom (personal interviews 2014). Yet, this would not appear in this data.

In order to put the robustness of the findings to an additional test and to get a sense of the size of the coefficients, the models are re-run implementing the indicator applied by Maystadt and Verwimp (2014) (see Table 3.6 in the appendix). They use the number of refugees weighted by the distance to the nearest settlement at the sub-county level. ${ }^{50}$ This means that, keeping district fixed effects, the variation between sub-counties within the same district is exploited. For a Ugandan household living nearby the settlement the distance would be equal to one so that the measure would be identical to the one applied in this study. For this case, the estimated marginal effect on consumption would be larger than in the main specification $(0.008$ as compared with 0.003 ) but would decrease with increasing distance. This is exactly what one would expect in case of spill-overs between sub-counties within a district. As sub-counties are a smaller administrative unit and distances between them are more easily travelled spill-overs are not surprising here. This finding underlines the appropriateness of districts rather than sub-counties as level of treatment. In their study, Maystadt and Verwimp (2014) find a marginal

\footnotetext{
${ }^{50}$ Sub-counties are an administrative unit below the level of districts.
} 
effect that is slightly smaller than the one estimated here. This was anticipated because of the more direct interaction between locals and refugees, the policy of local integration and the longer duration of the refugee presence. The other effects on government health services, private primary schooling and perceptions can also be confirmed with this measure.

When calculating the model at the district level (i.e., the level where the number of refugees is measured), some of the effects turn insignificant but especially the impact on private schooling and national identity does not vary (see Table 3.7 in the appendix).

\subsubsection{Instrumental Variable Approach}

It has been shown above that the crucial assumptions for an identification of the effect of refugees on the host population hold in the context of a natural experiment. In order to address possible remaining doubts about enodogeneity through unobserved heterogeneity an additional instrumental variable approach is applied. ${ }^{51}$ I take the total number of Congolese refugees entering Uganda in a given year and divide it by the districts' distance to the Congolese border. To provide for an adequate instrument, this measure should be a sufficient determinant of the number of refugees within a district. At the same time, it must not have a direct effect on households' consumption and perceptions as well as public service provision that does not work through the presence of refugees and is not controlled for given the other regressors in equation (2.1). The relevance of the instrument is benchmarked by the explanatory power of the first stage regression.

As for the exclusion restriction, the identifying assumption is made that the total number of Congolese refugees divided by the distance to the border affects the outcomes of interest only through a change in refugee intensity within the districts. The total number of refugees entering Uganda from the DRC flee from violent outbreaks in their own country. These are very unlikely to be directly linked to the outcomes under observation here. Additionally, violent events on the specific district's territory are controlled for. As explained above, settlements are set up close to the displaced persons' point of entry in order to facilitate their administration. This should also not be directly related to the outcomes of interest, especially as district fixed effects and the rural or urban status of a community are included in the estimation equation. Consequently, the resulting indicator is very highly correlated with the size of the settlements but both the variables that it consists of are arguably exogenous to the dependent variables analysed here.

Econometrically, to isolate the refugee-related component of the outcomes, I instrument refugee

\footnotetext{
${ }^{51}$ I would like to thank James Fenske who shared this idea at the Annual Bank Conference for Africa 2014 in Paris.
} 
Table 3.10: Instrumental Variable Approach, 2SLS Models, Second Stage, 2002-2010 (UNHS)

\begin{tabular}{|c|c|c|c|c|c|}
\hline & $\begin{array}{c}(1) \\
\log (\text { Consumption })\end{array}$ & $\begin{array}{l}(2) \\
\text { Gov. health }\end{array}$ & $\begin{array}{l}(3) \\
\text { Priv. health }\end{array}$ & $\begin{array}{c}(4) \\
\text { Gov. school }\end{array}$ & $\begin{array}{l}\quad(5) \\
\text { Priv. school }\end{array}$ \\
\hline Refugees per 1,000 & $\begin{array}{c}0.003^{* * *} \\
(0.001)\end{array}$ & $\begin{array}{c}-0.0003 \\
(0.002)\end{array}$ & $\begin{array}{c}-0.006^{* *} \\
(0.003)\end{array}$ & $\begin{array}{c}0.003 \\
(0.003)\end{array}$ & $\begin{array}{c}0.006^{* * *} \\
(0.002)\end{array}$ \\
\hline Wage*Refugees per 1,000 & $\begin{array}{l}-0.002^{*} \\
(0.0009)\end{array}$ & & & & \\
\hline Self-employed*Refugees per 1,000 & $\begin{array}{l}-0.002 \\
(0.001)\end{array}$ & & & & \\
\hline Property*Refugees per 1,000 & $\begin{array}{c}0.007 \\
(0.006)\end{array}$ & & & & \\
\hline Transfers*Refugees per 1,000 & $\begin{array}{c}-0.006^{* * *} \\
(0.001)\end{array}$ & & & & \\
\hline Year $=2005$ & $\begin{array}{c}0.1^{* * *} \\
(0.02)\end{array}$ & $\begin{array}{l}0.04^{*} \\
(0.02)\end{array}$ & $\begin{array}{c}0.2^{* * *} \\
(0.04)\end{array}$ & $\begin{array}{c}0.1^{* * *} \\
(0.04)\end{array}$ & $\begin{array}{c}0.03 \\
(0.04)\end{array}$ \\
\hline Year $=2010$ & $\begin{array}{l}0.4^{* * *} \\
(0.02)\end{array}$ & $\begin{array}{l}0.07^{* *} \\
(0.03)\end{array}$ & $\begin{array}{l}0.1^{* * *} \\
(0.05)\end{array}$ & $\begin{array}{l}0.2^{* * *} \\
(0.05)\end{array}$ & $\begin{array}{l}0.1^{* * *} \\
(0.05)\end{array}$ \\
\hline Observations & 10609 & 1126 & 1080 & 1124 & 990 \\
\hline Mean Outcome & 10.64 & 0.0879 & 0.337 & 0.384 & 0.348 \\
\hline Adj. R Squared & 0.328 & 0.0208 & 0.144 & 0.0375 & 0.146 \\
\hline
\end{tabular}

District fixed effects and control variables are included in all specifications.

Robust standard errors in parentheses. ${ }^{*} p<0.1,{ }^{* *} p<0.05,{ }^{* * *} p<0.01$

intensity using varying total annual numbers of refugees and distance to the border as an instrument in a two-stage least squares estimation. As presented in Tables 3.10 and 3.11, the results hold for the UNHS analysis and for the dominant identity both in terms of significance and of the size of the coefficients. Although the size of the coefficient remains similar to the main specifications for perceived living conditions, it turns insignificant. These tables only include the second stages of the estimations, the full tables showing also the first stage and the respective $\mathrm{F}$ statistics can be found in the appendix (Tables 3.8, 3.9, and 3.10). In all cases, the F statistics are above 30, thus indicating a strong instrument confirming the findings from the difference-in-difference models above.

Table 3.11: Instrumental Variable Approach, 2SLS Models, Second Stage, 2002-2010 (Afrobarometer)

\begin{tabular}{lcc}
\hline & $(1)$ & $(2)$ \\
& Living conditions & Ethnic identity \\
\hline Refugees per 1,000 & -0.005 & $0.005^{*}$ \\
& $(0.003)$ & $(0.003)$ \\
Year=2005 & 0.005 & $-0.05^{* *}$ \\
& $(0.02)$ & $(0.02)$ \\
Year=2010 & $0.05^{*}$ & $0.07^{* * *}$ \\
& $(0.03)$ & $(0.03)$ \\
\hline Observations & 3741 & 3608 \\
Mean Outcome & 0.400 & 0.233 \\
Adj. R Squared & 0.116 & 0.0379 \\
\hline District fixed effects and control variables are included in all specifications. \\
Robust standard errors in parentheses. ${ }^{*} p<0.1,{ }^{* *} p<0.05,{ }^{* * *} p<0.01$
\end{tabular}




\subsection{Conclusion}

This chapter carries out an analysis of both the impact of protracted refugee situations as well as of additional sudden inflows on the host population in Uganda, employing a differencein-differences and an instrumental variable approach. This case is especially interesting as Uganda is in the course of combining public service provision for refugees and hosts and of giving refugees more freedom to work and freedom of movement. These policy reforms affect the population living in nearby villages and at the same time they can only succeed if these important stakeholders are sufficiently included in the process.

The results presented here indicate that there is a division of tasks between the public and private sector regarding public infrastructure. While communities are more likely to have access to primary schools run by NGOs or other private organisations which raises their overall provision with this service, in the health sector the state appears to be overrun by demand and communities in refugee-hosting districts are less likely to have access to public clinics. This implies that, although already carried out, the coordination between international donors and local Ugandan governments can be improved, especially when it comes to common budgeting for refugees and hosts. While the official yardstick for successful integration is that Ugandans and displaced persons should be equally well off and, consequently, that refugee-hosting regions should not be better or worse off than non-hosting districts, a slight over-provision with public services (as seem in Table 3.8, columns 4 to 6 ) might be desirable. As representatives of international aid agencies and the Ugandan government stress, it is important for local populations to clearly perceive the benefits of hosting refugees in order to avoid conflicts between the two groups (personal interviews 2014).

While all employment groups can benefit from the increased population in their neighbourhood, some groups benefit significantly less and are vulnerable to losses due to sudden influxes, as they are directly forced into competition with refugees entering the labour market or requiring assisting transfers. Especially in the latter case, a sound analysis of the local contexts should be carried out in order to find a way to mitigate these negative effects. Those depending on financial assistance in the communities surrounding refugee settlements are very likely to be the most vulnerable share of the population. As they are not only unable to take a share in the beneficial effects of the refugees' presence but on top of that are negatively affected by them, ways have to be found to aim assistance at them, e.g., in the form of food aid or money.

Furthermore, the negative perceptions of the Ugandan population should not be ignored as they could threaten the whole approach of local integration. Subjective assessments can be confounded by multiple psychological effects and thus divert from objective measures, so that 
policy makers should not just rely on the latter ones. Further approaches should be sought to bring both groups together and allow them to reduce possible prejudices. Already, UNHCR organises meetings and workshops including the two groups; it appears that even more effort should be carried out in that direction. Again, it is important that the local population becomes aware of the benefits the refugees bring with them.

Yet, as none of the surveys considered refugees and the policies related to them, conclusions from this work should be taken with caution. There needs to be more data and research in general in order to get a clearer view of both the impact of refugees on their host populations in general as well as the Ugandan reforms specifically. 


\subsection{Appendix}

Table B1: Reduced Models for All Outcome Variables, Linear Probability Models, 2002-2010

\begin{tabular}{|c|c|c|c|c|c|c|c|}
\hline & $\begin{array}{c}(1) \\
\log (\text { Consumption })\end{array}$ & $\begin{array}{c}(2) \\
\text { Gov. health unit }\end{array}$ & $\begin{array}{c}(3) \\
\text { Priv. health unit }\end{array}$ & $\begin{array}{c}(4) \\
\text { Gov. primary school }\end{array}$ & $\begin{array}{c}(5) \\
\text { Priv. primary school }\end{array}$ & $\begin{array}{c}\text { (6) } \\
\text { Living conditions }\end{array}$ & $\begin{array}{c}(7) \\
\text { National or ethnic identity }\end{array}$ \\
\hline Refugees per 1,000 & $\begin{array}{c}0.002^{* * *} \\
(0.000)\end{array}$ & $\begin{array}{c}-0.0008^{* *} \\
(0.024)\end{array}$ & $\begin{array}{c}-0.003^{*} \\
(0.09)\end{array}$ & $\begin{array}{c}0.002^{* *} \\
(0.018)\end{array}$ & $\begin{array}{c}0.007^{* * *} \\
(0.000)\end{array}$ & $\begin{array}{c}-0.004^{* *} \\
(0.012)\end{array}$ & $\begin{array}{c}0.005^{* * *} \\
(0.000)\end{array}$ \\
\hline Year $=2005$ & $\begin{array}{l}0.08^{* * *} \\
(0.000)\end{array}$ & $\begin{array}{c}0.02 \\
(0.338)\end{array}$ & $\begin{array}{l}0.2^{* * * *} \\
(0.000)\end{array}$ & $\begin{array}{l}0.1^{* * *} \\
(0.008)\end{array}$ & $\begin{array}{l}-0.005 \\
(0.958)\end{array}$ & $\begin{array}{c}0.04 \\
(0.304)\end{array}$ & $\begin{array}{c}-0.05^{* * *} \\
(0.002)\end{array}$ \\
\hline Year $=2010$ & $\begin{array}{l}0.4^{* * *} \\
(0.000)\end{array}$ & $\begin{array}{l}0.05^{* *} \\
(0.042)\end{array}$ & $\begin{array}{l}0.1^{* * *} \\
(0.01)\end{array}$ & $\begin{array}{l}0.2^{* * *} \\
(0.000)\end{array}$ & $\begin{array}{l}0.1^{* * *} \\
(0.006)\end{array}$ & $\begin{array}{l}0.1^{* * *} \\
(0.002)\end{array}$ & $\begin{array}{l}0.06^{*} \\
(0.06)\end{array}$ \\
\hline Observations & 10831 & 1126 & 1080 & 1124 & 990 & 3764 & 3628 \\
\hline Mean outcome & 10.64 & 0.088 & 0.34 & 0.38 & 0.35 & 0.400 & 0.233 \\
\hline R Squared & 0.149 & 0.0422 & 0.126 & 0.0671 & 0.150 & 0.0451 & 0.0445 \\
\hline
\end{tabular}

P-values from bootstrapping standard errors in parentheses. Standard errors are clustered at the district level.

District fixed effects are included in all specifications.

${ }^{*} p<0.1,{ }^{* *} p<0.05,{ }^{* * *} p<0.01$ 
Table 3.2: Household Welfare by Main Income Source, Displaying Control Variables, Linear Probability Models, 2002-2010

\begin{tabular}{|c|c|c|c|}
\hline & \multicolumn{3}{|c|}{$\log ($ Consumption $)$} \\
\hline & (1) & (2) & (3) \\
\hline Refugees per 1,000 & $\begin{array}{c}0.003^{* * *} \\
(0.0009)\end{array}$ & $\begin{array}{c}0.001 \\
(0.0007)\end{array}$ & $\begin{array}{c}0.002^{* * *} \\
(0.0005)\end{array}$ \\
\hline Maximum increase & & $\begin{array}{c}8.4^{* * *} \\
(1.8)\end{array}$ & \\
\hline Radius 60 km & & & $\begin{array}{l}0.05 \\
(0.05)\end{array}$ \\
\hline Wage & $\begin{array}{l}0.1^{* * *} \\
(0.03)\end{array}$ & $\begin{array}{l}0.1^{* * *} \\
(0.03)\end{array}$ & $\begin{array}{l}0.1^{* * *} \\
(0.03)\end{array}$ \\
\hline Self-employed & $\begin{array}{l}0.2^{* * *} \\
(0.02)\end{array}$ & $\begin{array}{l}0.2^{* * *} \\
(0.02)\end{array}$ & $\begin{array}{l}0.2^{* * *} \\
(0.02)\end{array}$ \\
\hline Property & $\begin{array}{c}0.3^{* * *} \\
(0.1)\end{array}$ & $\begin{array}{l}0.3^{* * *} \\
(0.10)\end{array}$ & $\begin{array}{c}0.3^{* * *} \\
(0.1)\end{array}$ \\
\hline Transfers & $\begin{array}{l}0.2^{* * *} \\
(0.05)\end{array}$ & $\begin{array}{l}0.1^{* * *} \\
(0.05)\end{array}$ & $\begin{array}{l}0.2^{* * *} \\
(0.05)\end{array}$ \\
\hline Year $=2005$ & $\begin{array}{l}0.1^{* * *} \\
(0.02)\end{array}$ & $\begin{array}{l}0.1^{* * *} \\
(0.02)\end{array}$ & $\begin{array}{l}0.1^{* * *} \\
(0.02)\end{array}$ \\
\hline Year $=2010$ & $\begin{array}{l}0.4^{* * *} \\
(0.03)\end{array}$ & $\begin{array}{l}0.4^{* * *} \\
(0.03)\end{array}$ & $\begin{array}{l}0.4^{* * *} \\
(0.03)\end{array}$ \\
\hline Night-time light $(\log )$ & $\begin{array}{l}0.001 \\
(0.004)\end{array}$ & $\begin{array}{c}0.001 \\
(0.004)\end{array}$ & $\begin{array}{c}0.001 \\
(0.005)\end{array}$ \\
\hline Urban & $\begin{array}{l}0.3^{* * *} \\
(0.03)\end{array}$ & $\begin{array}{l}0.3^{* * *} \\
(0.03)\end{array}$ & $\begin{array}{l}0.3^{* * *} \\
(0.03)\end{array}$ \\
\hline Population in 1,000 & $\begin{array}{c}0.0000006^{* * *} \\
(0.0000001)\end{array}$ & $\begin{array}{c}0.0000006^{* * *} \\
(0.0000001)\end{array}$ & $\begin{array}{c}0.0000006^{* * *} \\
(0.0000001)\end{array}$ \\
\hline Distance border & $\begin{array}{c}0.002^{*} \\
(0.0008)\end{array}$ & $\begin{array}{c}0.002^{*} \\
(0.0008)\end{array}$ & $\begin{array}{c}0.002^{*} \\
(0.0008)\end{array}$ \\
\hline Distance Kampala & $\begin{array}{l}-0.0002 \\
(0.0008)\end{array}$ & $\begin{array}{l}-0.0002 \\
(0.0008)\end{array}$ & $\begin{array}{l}-0.0003 \\
(0.0008)\end{array}$ \\
\hline Violent events & $\begin{array}{l}0.008 \\
(0.02)\end{array}$ & $\begin{array}{l}0.005 \\
(0.02)\end{array}$ & $\begin{array}{l}0.008 \\
(0.02)\end{array}$ \\
\hline Age & $\begin{array}{c}0.004 \\
(0.004)\end{array}$ & $\begin{array}{c}0.004 \\
(0.004)\end{array}$ & $\begin{array}{c}0.004 \\
(0.004)\end{array}$ \\
\hline Age squared & $\begin{array}{l}-0.00002 \\
(0.00004)\end{array}$ & $\begin{array}{l}-0.00002 \\
(0.00004)\end{array}$ & $\begin{array}{l}-0.00001 \\
(0.00004)\end{array}$ \\
\hline Male & $\begin{array}{c}0.02 \\
(0.01)\end{array}$ & $\begin{array}{c}0.02 \\
(0.01)\end{array}$ & $\begin{array}{c}0.02 \\
(0.01)\end{array}$ \\
\hline Household members & $\begin{array}{c}-0.04^{* * *} \\
(0.003)\end{array}$ & $\begin{array}{c}-0.04^{* * *} \\
(0.003)\end{array}$ & $\begin{array}{c}-0.04^{* * *} \\
(0.003)\end{array}$ \\
\hline Highest grade & $\begin{array}{l}0.04^{* * *} \\
(0.001)\end{array}$ & $\begin{array}{l}0.04^{* * *} \\
(0.001)\end{array}$ & $\begin{array}{l}0.04^{* * *} \\
(0.001)\end{array}$ \\
\hline Observations & 10623 & 10623 & 10623 \\
\hline Mean Consumption & 10.64 & 10.64 & 10.64 \\
\hline R Squared & 0.331 & 0.332 & 0.331 \\
\hline
\end{tabular}


Table 3.3: Public and Private Health Service Provision, Displaying Control Variables, Linear Probability Models, 2002-2010

\begin{tabular}{|c|c|c|c|c|c|c|}
\hline & \multicolumn{3}{|c|}{ Government health unit } & \multicolumn{3}{|c|}{ Private health unit } \\
\hline & (1) & (2) & (3) & (4) & (5) & (6) \\
\hline Refugees per 1,000 & $\begin{array}{c}-0.0008^{* *} \\
(0.0003)\end{array}$ & $\begin{array}{c}-0.0009^{* * *} \\
(0.0003)\end{array}$ & $\begin{array}{c}-0.001 \\
(0.0007)\end{array}$ & $\begin{array}{c}-0.003^{*} \\
(0.001)\end{array}$ & $\begin{array}{c}-0.002^{*} \\
(0.001)\end{array}$ & $\begin{array}{c}-0.002 \\
(0.002)\end{array}$ \\
\hline Maximum increase & & & $\begin{array}{c}0.8 \\
(1.9)\end{array}$ & & & $\begin{array}{l}-2.5^{*} \\
(1.5)\end{array}$ \\
\hline Radius $60 \mathrm{~km}$ & & $\begin{array}{l}0.08^{* *} \\
(0.04)\end{array}$ & & & $\begin{array}{l}-0.06 \\
(0.05)\end{array}$ & \\
\hline Year $=2005$ & $\begin{array}{l}0.04^{*} \\
(0.02)\end{array}$ & $\begin{array}{l}0.04^{*} \\
(0.02)\end{array}$ & $\begin{array}{l}0.04^{*} \\
(0.02)\end{array}$ & $\begin{array}{l}0.2^{* * *} \\
(0.03)\end{array}$ & $\begin{array}{l}0.2^{* * *} \\
(0.03)\end{array}$ & $\begin{array}{l}0.2^{* * *} \\
(0.03)\end{array}$ \\
\hline Year $=2010$ & $\begin{array}{c}0.07^{* *} \\
(0.03)\end{array}$ & $\begin{array}{c}0.08^{* *} \\
(0.03)\end{array}$ & $\begin{array}{c}0.07^{* *} \\
(0.03)\end{array}$ & $\begin{array}{l}0.1^{* *} \\
(0.05)\end{array}$ & $\begin{array}{l}0.1^{* *} \\
(0.05)\end{array}$ & $\begin{array}{l}0.1^{* *} \\
(0.05)\end{array}$ \\
\hline Night-time light (log) & $\begin{array}{c}0.002 \\
(0.001)\end{array}$ & $\begin{array}{l}0.0010 \\
(0.002)\end{array}$ & $\begin{array}{c}0.002 \\
(0.001)\end{array}$ & $\begin{array}{l}-0.004 \\
(0.007)\end{array}$ & $\begin{array}{l}-0.003 \\
(0.007)\end{array}$ & $\begin{array}{l}-0.003 \\
(0.007)\end{array}$ \\
\hline Urban & $\begin{array}{c}0.07^{* * *} \\
(0.03)\end{array}$ & $\begin{array}{c}0.07^{* * *} \\
(0.02)\end{array}$ & $\begin{array}{c}0.07^{* * *} \\
(0.03)\end{array}$ & $\begin{array}{l}0.3^{* * *} \\
(0.04)\end{array}$ & $\begin{array}{l}0.3^{* * *} \\
(0.04)\end{array}$ & $\begin{array}{l}0.3^{* * *} \\
(0.04)\end{array}$ \\
\hline Population in 1,000 & $\begin{array}{c}-0.00000008 \\
(0.0000002)\end{array}$ & $\begin{array}{c}-0.00000008 \\
(0.0000002)\end{array}$ & $\begin{array}{c}-0.00000008 \\
(0.0000002)\end{array}$ & $\begin{array}{c}0.0000003 \\
(0.0000002)\end{array}$ & $\begin{array}{c}0.0000003 \\
(0.0000002)\end{array}$ & $\begin{array}{c}0.0000003 \\
(0.0000002)\end{array}$ \\
\hline Distance border & $\begin{array}{l}-0.0008 \\
(0.0006)\end{array}$ & $\begin{array}{l}-0.0005 \\
(0.0005)\end{array}$ & $\begin{array}{l}-0.0008 \\
(0.0006)\end{array}$ & $\begin{array}{c}-0.0004 \\
(0.0008)\end{array}$ & $\begin{array}{l}-0.0005 \\
(0.0008)\end{array}$ & $\begin{array}{l}-0.0004 \\
(0.0008)\end{array}$ \\
\hline Distance Kampala & $\begin{array}{l}-0.001^{*} \\
(0.0005)\end{array}$ & $\begin{array}{c}-0.001^{* *} \\
(0.0005)\end{array}$ & $\begin{array}{l}-0.001^{*} \\
(0.0005)\end{array}$ & $\begin{array}{l}-0.001 \\
(0.001)\end{array}$ & $\begin{array}{c}-0.001 \\
(0.0010)\end{array}$ & $\begin{array}{l}-0.001 \\
(0.001)\end{array}$ \\
\hline Violent events & $\begin{array}{l}0.007 \\
(0.02)\end{array}$ & $\begin{array}{l}0.007 \\
(0.02)\end{array}$ & $\begin{array}{l}0.007 \\
(0.02)\end{array}$ & $\begin{array}{c}0.03 \\
(0.02)\end{array}$ & $\begin{array}{c}0.03 \\
(0.02)\end{array}$ & $\begin{array}{c}0.03 \\
(0.02)\end{array}$ \\
\hline Observations & 1126 & 1126 & 1126 & 1080 & 1080 & 1080 \\
\hline Mean Provision & 0.0879 & 0.0879 & 0.0879 & 0.337 & 0.337 & 0.337 \\
\hline R Squared & 0.0559 & 0.0595 & 0.0559 & 0.178 & 0.178 & 0.178 \\
\hline
\end{tabular}


Table 3.4: Public and Private Primary Education, Displaying Control Variables, Linear Probability Models, 2002-2010

\begin{tabular}{|c|c|c|c|c|c|c|}
\hline & \multicolumn{3}{|c|}{ Government primary school } & \multicolumn{3}{|c|}{ Private primary school } \\
\hline & (1) & $(2)$ & $(3)$ & (4) & $(5)$ & (6) \\
\hline Refugees per 1,000 & $\begin{array}{c}0.0009 \\
(0.0008)\end{array}$ & $\begin{array}{c}0.0010 \\
(0.0008)\end{array}$ & $\begin{array}{c}-0.0002 \\
(0.001)\end{array}$ & $\begin{array}{c}0.006^{* * *} \\
(0.002)\end{array}$ & $\begin{array}{c}0.006^{* *} \\
(0.002)\end{array}$ & $\begin{array}{l}0.006^{* * *} \\
(0.0005)\end{array}$ \\
\hline Maximum increase & & & $\begin{array}{c}5.1 \\
(5.9)\end{array}$ & & & $\begin{array}{c}1.9 \\
(10.9)\end{array}$ \\
\hline Radius 60 km & & $\begin{array}{l}-0.06 \\
(0.09)\end{array}$ & & & $\begin{array}{c}0.08 \\
(0.08)\end{array}$ & \\
\hline Year $=2005$ & $\begin{array}{l}0.1^{* *} \\
(0.05)\end{array}$ & $\begin{array}{l}0.1^{* *} \\
(0.05)\end{array}$ & $\begin{array}{l}0.1^{* *} \\
(0.05)\end{array}$ & $\begin{array}{c}0.03 \\
(0.04)\end{array}$ & $\begin{array}{c}0.02 \\
(0.04)\end{array}$ & $\begin{array}{c}0.03 \\
(0.04)\end{array}$ \\
\hline Year $=2010$ & $\begin{array}{l}0.2^{* * *} \\
(0.06)\end{array}$ & $\begin{array}{l}0.2^{* * *} \\
(0.06)\end{array}$ & $\begin{array}{l}0.2^{* * *} \\
(0.06)\end{array}$ & $\begin{array}{l}0.1^{* * *} \\
(0.04)\end{array}$ & $\begin{array}{l}0.1^{* * *} \\
(0.04)\end{array}$ & $\begin{array}{l}0.1^{* * *} \\
(0.04)\end{array}$ \\
\hline Night-time light (log) & $\begin{array}{c}0.008 \\
(0.006)\end{array}$ & $\begin{array}{c}0.008 \\
(0.006)\end{array}$ & $\begin{array}{c}0.007 \\
(0.006)\end{array}$ & $\begin{array}{c}-0.0004 \\
(0.005)\end{array}$ & $\begin{array}{l}-0.001 \\
(0.005)\end{array}$ & $\begin{array}{l}-0.0005 \\
(0.005)\end{array}$ \\
\hline Urban & $\begin{array}{l}-0.02 \\
(0.04)\end{array}$ & $\begin{array}{l}-0.01 \\
(0.04)\end{array}$ & $\begin{array}{l}-0.02 \\
(0.04)\end{array}$ & $\begin{array}{l}0.2^{* * *} \\
(0.03)\end{array}$ & $\begin{array}{l}0.2^{* * *} \\
(0.03)\end{array}$ & $\begin{array}{l}0.2^{* * *} \\
(0.03)\end{array}$ \\
\hline Population in 1,000 & $\begin{array}{c}0.00000002 \\
(0.0000003)\end{array}$ & $\begin{array}{l}0.00000002 \\
(0.0000003)\end{array}$ & $\begin{array}{l}0.00000002 \\
(0.0000003)\end{array}$ & $\begin{array}{c}0.0000006^{* * *} \\
(0.0000002)\end{array}$ & $\begin{array}{c}0.0000006^{* * *} \\
(0.0000002)\end{array}$ & $\begin{array}{c}0.0000006^{* * *} \\
(0.0000002)\end{array}$ \\
\hline Distance border & $\begin{array}{l}-0.002 \\
(0.0009)\end{array}$ & $\begin{array}{l}-0.002^{*} \\
(0.0009)\end{array}$ & $\begin{array}{l}-0.002 \\
(0.0009)\end{array}$ & $\begin{array}{l}0.003^{* *} \\
(0.001)\end{array}$ & $\begin{array}{l}0.003^{* *} \\
(0.001)\end{array}$ & $\begin{array}{l}0.003^{* *} \\
(0.001)\end{array}$ \\
\hline Distance Kampala & $\begin{array}{l}-0.001 \\
(0.0010)\end{array}$ & $\begin{array}{l}-0.001 \\
(0.0010)\end{array}$ & $\begin{array}{l}-0.0010 \\
(0.001)\end{array}$ & $\begin{array}{r}-0.00010 \\
(0.0010)\end{array}$ & $\begin{array}{c}-0.0002 \\
(0.001)\end{array}$ & $\begin{array}{r}-0.00008 \\
(0.0010)\end{array}$ \\
\hline Violent events & $\begin{array}{c}-0.04 \\
(0.03)\end{array}$ & $\begin{array}{l}-0.04 \\
(0.03)\end{array}$ & $\begin{array}{l}-0.04 \\
(0.03)\end{array}$ & $\begin{array}{l}-0.03 \\
(0.02)\end{array}$ & $\begin{array}{l}-0.03 \\
(0.02)\end{array}$ & $\begin{array}{l}-0.03 \\
(0.02)\end{array}$ \\
\hline Observations & 1124 & 1124 & 1124 & 990 & 990 & 990 \\
\hline Mean Provision & 0.384 & 0.384 & 0.384 & 0.348 & 0.348 & 0.348 \\
\hline R Squared & 0.0717 & 0.0724 & 0.0725 & 0.185 & 0.186 & 0.185 \\
\hline
\end{tabular}


Table 3.5: Households' Perceptions, Displaying Control Variables, Linear Probability Models, 2002-2010

\begin{tabular}{|c|c|c|c|c|c|c|}
\hline & \multicolumn{3}{|c|}{ Living conditions } & \multicolumn{3}{|c|}{ Ethnic rather than national identity } \\
\hline & (1) & (2) & (3) & (4) & $(5)$ & (6) \\
\hline Refugees per 1,000 & $\begin{array}{c}-0.004^{*} \\
(0.002)\end{array}$ & $\begin{array}{l}-0.004^{*} \\
(0.002)\end{array}$ & $\begin{array}{l}-0.005^{*} \\
(0.003)\end{array}$ & $\begin{array}{c}0.007^{* * *} \\
(0.002)\end{array}$ & $\begin{array}{c}0.007^{* * *} \\
(0.002)\end{array}$ & $\begin{array}{c}0.009^{* * * *} \\
(0.003)\end{array}$ \\
\hline Maximum increase & & & $\begin{array}{c}2.3 \\
(3.5)\end{array}$ & & & $\begin{array}{l}-6.4 \\
(4.6)\end{array}$ \\
\hline Radius $60 \mathrm{~km}$ & & $\begin{array}{c}-0.08^{* * *} \\
(0.03)\end{array}$ & & & $\begin{array}{c}0.04 \\
(0.04)\end{array}$ & \\
\hline Year $=2005$ & $\begin{array}{l}-0.02 \\
(0.03)\end{array}$ & $\begin{array}{l}-0.01 \\
(0.03)\end{array}$ & $\begin{array}{l}-0.02 \\
(0.04)\end{array}$ & $\begin{array}{c}-0.05^{* *} \\
(0.02)\end{array}$ & $\begin{array}{c}-0.05^{* *} \\
(0.02)\end{array}$ & $\begin{array}{l}-0.04^{*} \\
(0.02)\end{array}$ \\
\hline Year $=2010$ & $\begin{array}{c}0.04 \\
(0.03)\end{array}$ & $\begin{array}{c}0.04 \\
(0.03)\end{array}$ & $\begin{array}{c}0.04 \\
(0.03)\end{array}$ & $\begin{array}{l}0.08^{*} \\
(0.04)\end{array}$ & $\begin{array}{l}0.07^{*} \\
(0.04)\end{array}$ & $\begin{array}{l}0.07^{*} \\
(0.04)\end{array}$ \\
\hline Night-time light $(\log )$ & $\begin{array}{c}-0.01^{* * * *} \\
(0.002)\end{array}$ & $\begin{array}{c}-0.01^{* * *} \\
(0.002)\end{array}$ & $\begin{array}{c}-0.01^{* * *} \\
(0.003)\end{array}$ & $\begin{array}{l}-0.002 \\
(0.002)\end{array}$ & $\begin{array}{l}-0.002 \\
(0.002)\end{array}$ & $\begin{array}{l}-0.001 \\
(0.003)\end{array}$ \\
\hline Urban & $\begin{array}{l}-0.02 \\
(0.03)\end{array}$ & $\begin{array}{l}-0.02 \\
(0.03)\end{array}$ & $\begin{array}{l}-0.02 \\
(0.03)\end{array}$ & $\begin{array}{c}0.01 \\
(0.02)\end{array}$ & $\begin{array}{c}0.01 \\
(0.02)\end{array}$ & $\begin{array}{c}0.01 \\
(0.02)\end{array}$ \\
\hline Population in 1,000 & $\begin{array}{c}0.0000006^{* * *} \\
(0.0000002)\end{array}$ & $\begin{array}{c}0.0000006^{* * *} \\
(0.0000002)\end{array}$ & $\begin{array}{c}0.0000006^{* * *} \\
(0.0000002)\end{array}$ & $\begin{array}{l}-0.0000004 \\
(0.0000002)\end{array}$ & $\begin{array}{l}-0.0000004 \\
(0.0000002)\end{array}$ & $\begin{array}{l}-0.0000003 \\
(0.0000002)\end{array}$ \\
\hline Distance border & $\begin{array}{c}0.002 \\
(0.005)\end{array}$ & $\begin{array}{c}0.001 \\
(0.005)\end{array}$ & $\begin{array}{c}0.003 \\
(0.006)\end{array}$ & $\begin{array}{l}-0.002 \\
(0.007)\end{array}$ & $\begin{array}{l}-0.001 \\
(0.007)\end{array}$ & $\begin{array}{l}-0.005 \\
(0.006)\end{array}$ \\
\hline Distance Kampala & $\begin{array}{l}0.02^{* * *} \\
(0.005)\end{array}$ & $\begin{array}{c}0.02^{* * *} \\
(0.005)\end{array}$ & $\begin{array}{c}0.02^{* * *} \\
(0.005)\end{array}$ & $\begin{array}{l}-0.003 \\
(0.006)\end{array}$ & $\begin{array}{l}-0.004 \\
(0.006)\end{array}$ & $\begin{array}{l}-0.007 \\
(0.005)\end{array}$ \\
\hline Violent events & $\begin{array}{c}0.02 \\
(0.01)\end{array}$ & $\begin{array}{c}0.02 \\
(0.01)\end{array}$ & $\begin{array}{c}0.02 \\
(0.01)\end{array}$ & $\begin{array}{l}0.03^{* *} \\
(0.01)\end{array}$ & $\begin{array}{l}0.03^{* *} \\
(0.02)\end{array}$ & $\begin{array}{l}0.03^{* *} \\
(0.01)\end{array}$ \\
\hline Age & $\begin{array}{l}-0.007^{*} \\
(0.003)\end{array}$ & $\begin{array}{c}-0.007^{*} \\
(0.003)\end{array}$ & $\begin{array}{l}-0.007^{*} \\
(0.003)\end{array}$ & $\begin{array}{l}-0.002 \\
(0.003)\end{array}$ & $\begin{array}{l}-0.002 \\
(0.003)\end{array}$ & $\begin{array}{l}-0.002 \\
(0.003)\end{array}$ \\
\hline Age squared & $\begin{array}{c}0.00007 \\
(0.00004)\end{array}$ & $\begin{array}{c}0.00007 \\
(0.00004)\end{array}$ & $\begin{array}{c}0.00007 \\
(0.00004)\end{array}$ & $\begin{array}{l}0.000008 \\
(0.00004)\end{array}$ & $\begin{array}{l}0.000008 \\
(0.00004)\end{array}$ & $\begin{array}{l}0.000008 \\
(0.00004)\end{array}$ \\
\hline Male & $\begin{array}{l}-0.02 \\
(0.02)\end{array}$ & $\begin{array}{l}-0.02 \\
(0.02)\end{array}$ & $\begin{array}{l}-0.02 \\
(0.02)\end{array}$ & $\begin{array}{l}0.01 \\
(0.01)\end{array}$ & $\begin{array}{c}0.01 \\
(0.01)\end{array}$ & $\begin{array}{l}0.01 \\
(0.01)\end{array}$ \\
\hline Highest grade & $\begin{array}{l}0.02^{* * *} \\
(0.005)\end{array}$ & $\begin{array}{l}0.02^{* * *} \\
(0.005)\end{array}$ & $\begin{array}{l}0.02^{* * *} \\
(0.005)\end{array}$ & $\begin{array}{l}-0.004 \\
(0.005)\end{array}$ & $\begin{array}{l}-0.004 \\
(0.005)\end{array}$ & $\begin{array}{l}-0.004 \\
(0.005)\end{array}$ \\
\hline Gone w/o food & $\begin{array}{c}-0.06^{* * *} \\
(0.01)\end{array}$ & $\begin{array}{c}-0.06^{* * *} \\
(0.01)\end{array}$ & $\begin{array}{c}-0.06^{* * *} \\
(0.01)\end{array}$ & $\begin{array}{r}-0.0010 \\
(0.009)\end{array}$ & $\begin{array}{l}-0.0010 \\
(0.009)\end{array}$ & $\begin{array}{l}-0.0006 \\
(0.009)\end{array}$ \\
\hline Gone w/o water & $\begin{array}{l}-0.002 \\
(0.008)\end{array}$ & $\begin{array}{l}-0.002 \\
(0.008)\end{array}$ & $\begin{array}{l}-0.002 \\
(0.008)\end{array}$ & $\begin{array}{l}0.01^{* *} \\
(0.005)\end{array}$ & $\begin{array}{l}0.01^{* *} \\
(0.005)\end{array}$ & $\begin{array}{l}0.01^{* *} \\
(0.005)\end{array}$ \\
\hline Gone w/o medical care & $\begin{array}{c}-0.07^{* * *} \\
(0.01)\end{array}$ & $\begin{array}{c}-0.07^{* * *} \\
(0.01)\end{array}$ & $\begin{array}{c}-0.07^{* * *} \\
(0.01)\end{array}$ & $\begin{array}{l}-0.005 \\
(0.008)\end{array}$ & $\begin{array}{l}-0.005 \\
(0.008)\end{array}$ & $\begin{array}{l}-0.005 \\
(0.008)\end{array}$ \\
\hline Radio news & $\begin{array}{l}0.02^{* * *} \\
(0.008) \\
\end{array}$ & $\begin{array}{l}0.02^{* * *} \\
(0.008) \\
\end{array}$ & $\begin{array}{l}0.02^{* * *} \\
(0.008) \\
\end{array}$ & $\begin{array}{c}-0.004 \\
(0.009) \\
\end{array}$ & $\begin{array}{l}-0.004 \\
(0.009) \\
\end{array}$ & $\begin{array}{l}-0.004 \\
(0.009) \\
\end{array}$ \\
\hline Observations & 3741 & 3741 & 3741 & 3608 & 3608 & 3608 \\
\hline Mean Perception & 0.400 & 0.400 & 0.400 & 0.233 & 0.233 & 0.233 \\
\hline R Squared & 0.128 & 0.129 & 0.128 & 0.0492 & 0.0493 & 0.0497 \\
\hline
\end{tabular}


Table 3.6: Replacing Refugee Levels with the M-V Indicator, Linear Probability Models, 2002-2010

\begin{tabular}{|c|c|c|c|c|c|}
\hline & $\begin{array}{c}(1) \\
\log (\text { Consumption })\end{array}$ & Gov. health & $\begin{array}{l}(3) \\
\text { Priv. health }\end{array}$ & $\begin{array}{c}(4) \\
\text { Gov. school }\end{array}$ & $\begin{array}{l}\text { (5) } \\
\text { Priv. school }\end{array}$ \\
\hline Maystadt/ Verwimp indicator & $\begin{array}{c}0.009^{*} \\
(0.08)\end{array}$ & $\begin{array}{c}-0.01^{* * *} \\
(0.002)\end{array}$ & $\begin{array}{c}0.00008 \\
(1.0)\end{array}$ & $\begin{array}{l}0.0004 \\
(0.994)\end{array}$ & $\begin{array}{l}0.07^{* * *} \\
(0.000)\end{array}$ \\
\hline Year $=2005$ & $\begin{array}{l}0.1^{* * *} \\
(0.000)\end{array}$ & $\begin{array}{l}0.04^{*} \\
(0.06)\end{array}$ & $\begin{array}{l}0.2^{* * *} \\
(0.000)\end{array}$ & $\begin{array}{c}0.1^{* *} \\
(0.028)\end{array}$ & $\begin{array}{c}0.02 \\
(0.582)\end{array}$ \\
\hline Year $=2010$ & $\begin{array}{l}0.4^{* * *} \\
(0.000)\end{array}$ & $\begin{array}{l}0.07^{* *} \\
(0.012)\end{array}$ & $\begin{array}{c}0.1^{* *} \\
(0.026)\end{array}$ & $\begin{array}{l}0.2^{* * *} \\
(0.006)\end{array}$ & $\begin{array}{l}0.1^{* * *} \\
(0.000)\end{array}$ \\
\hline Observations & 10609 & 1126 & 1080 & 1124 & 990 \\
\hline Mean outcome & 10.64 & 0.088 & 0.34 & 0.38 & 0.35 \\
\hline R Squared & 0.332 & 0.0549 & 0.176 & 0.0711 & 0.187 \\
\hline
\end{tabular}

\begin{tabular}{lcc}
\hline & $(6)$ & $(7)$ \\
& Living conditions & Ethnic identity \\
\hline Maystadt/ Verwimp measure & $-0.249^{* *}$ & $0.311^{* *}$ \\
& $(0.012)$ & $(.0 .014)$ \\
Year=2005 & 0.0006 & $-0.05^{* * *}$ \\
& $(1.0)$ & $(0.006)$ \\
Year=2010 & 0.04 & 0.07 \\
& $(0.132)$ & $(0.124)$ \\
\hline Observations & 3741 & 3608 \\
Mean outcome & 0.400 & 0.233 \\
R Squared & 0.126 & 0.0492 \\
\hline
\end{tabular}

P-values from bootstrapping standard errors in parentheses. Standard errors are clustered

at the district level. District fixed effects and control variables are included in all specifications.

${ }^{*} p<0.1,{ }^{* *} p<0.05,{ }^{* * *} p<0.01$ 
Table 3.7: District Level Analysis, Linear Probability Models, 2002-2010

\begin{tabular}{|c|c|c|c|c|c|}
\hline & $\begin{array}{c}(1) \\
\log (\text { Consumption })\end{array}$ & Gov. health & $\begin{array}{l}(3) \\
\text { Priv. health }\end{array}$ & $\begin{array}{l}(4) \\
\text { Gov. school }\end{array}$ & $\begin{array}{l}(5) \\
\text { Priv. school }\end{array}$ \\
\hline Refugees per 1,000 & $\begin{array}{c}0.002^{*} \\
(0.0009)\end{array}$ & $\begin{array}{l}-0.0008 \\
(0.0005)\end{array}$ & $\begin{array}{c}-0.002^{* * *} \\
(0.0007)\end{array}$ & $\begin{array}{c}0.0009 \\
(0.0008)\end{array}$ & $\begin{array}{l}0.006^{* * *} \\
(0.0005)\end{array}$ \\
\hline Wage & $\begin{array}{c}0.1^{* * *} \\
(0.02)\end{array}$ & & & & \\
\hline Self-employed & $\begin{array}{c}0.2^{* * *} \\
(0.02)\end{array}$ & & & & \\
\hline Property & $\begin{array}{l}0.4^{* * *} \\
(0.07)\end{array}$ & & & & \\
\hline Transfers & $\begin{array}{l}0.1^{* * *} \\
(0.03)\end{array}$ & & & & \\
\hline Year $=2005$ & $\begin{array}{l}0.1^{* * *} \\
(0.02)\end{array}$ & $\begin{array}{l}0.04^{* * *} \\
(0.007)\end{array}$ & $\begin{array}{l}0.2^{* * *} \\
(0.01)\end{array}$ & $\begin{array}{l}0.1^{* * *} \\
(0.01)\end{array}$ & $\begin{array}{l}0.03^{* *} \\
(0.01)\end{array}$ \\
\hline Year $=2010$ & $\begin{array}{l}0.4^{* * *} \\
(0.02)\end{array}$ & $\begin{array}{c}0.07 * * * \\
(0.01)\end{array}$ & $\begin{array}{l}0.1^{* * *} \\
(0.02)\end{array}$ & $\begin{array}{l}0.2^{* * *} \\
(0.02)\end{array}$ & $\begin{array}{l}0.1^{* * *} \\
(0.02)\end{array}$ \\
\hline Night-time light (log) & $\begin{array}{c}0.002 \\
(0.003)\end{array}$ & $\begin{array}{c}0.002 \\
(0.001)\end{array}$ & $\begin{array}{l}-0.003 \\
(0.002)\end{array}$ & $\begin{array}{c}0.007^{* * *} \\
(0.002)\end{array}$ & $\begin{array}{c}-0.00006 \\
(0.002)\end{array}$ \\
\hline Urban & $\begin{array}{l}0.3^{* * *} \\
(0.02)\end{array}$ & $\begin{array}{l}0.08^{* * *} \\
(0.007)\end{array}$ & $\begin{array}{l}0.2^{* * *} \\
(0.01)\end{array}$ & $\begin{array}{l}-0.01 \\
(0.01)\end{array}$ & $\begin{array}{l}0.2^{* * *} \\
(0.01)\end{array}$ \\
\hline Population in 1,000 & $\begin{array}{c}0.0000005^{* * *} \\
(0.0000002)\end{array}$ & $\begin{array}{l}-0.00000004 \\
(0.00000009)\end{array}$ & $\begin{array}{c}0.0000003^{* *} \\
(0.0000001)\end{array}$ & $\begin{array}{l}0.00000006 \\
(0.0000001)\end{array}$ & $\begin{array}{c}0.0000006^{* * *} \\
(0.0000001)\end{array}$ \\
\hline Distance border & $\begin{array}{l}0.002^{* * *} \\
(0.0004)\end{array}$ & $\begin{array}{l}-0.0001 \\
(0.0002)\end{array}$ & $\begin{array}{c}0.0005 \\
(0.0003)\end{array}$ & $\begin{array}{c}-0.0009^{* *} \\
(0.0004)\end{array}$ & $\begin{array}{c}0.003^{* * *} \\
(0.0004)\end{array}$ \\
\hline Violent events & $\begin{array}{l}0.010 \\
(0.01)\end{array}$ & $\begin{array}{c}0.007 \\
(0.006)\end{array}$ & $\begin{array}{l}0.03^{* * *} \\
(0.009)\end{array}$ & $\begin{array}{c}-0.04^{* * *} \\
(0.009)\end{array}$ & $\begin{array}{c}-0.03^{* * *} \\
(0.009)\end{array}$ \\
\hline Observations & 10609 & 10802 & 10347 & 10783 & 9455 \\
\hline Mean Outcome & 10.64 & 0.0873 & 0.333 & 0.384 & 0.346 \\
\hline R Squared & 0.332 & 0.0512 & 0.173 & 0.0699 & 0.186 \\
\hline
\end{tabular}

Standard errors in parentheses

District fixed effects and control variables included in all specifications.

${ }^{*} p<0.1,{ }^{* *} p<0.05,{ }^{* * *} p<0.01$

\begin{tabular}{lcc}
\hline & $(1)$ & $(2)$ \\
& Living conditions & National identity \\
\hline Refugees per 1,000 & $-0.006^{* * *}$ & $0.006^{* * *}$ \\
Year=2005 & $(0.002)$ & $(0.002)$ \\
& 0.03 & -0.02 \\
Year=2010 & $(0.04)$ & $(0.03)$ \\
& 0.05 & 0.04 \\
Night-time light (log) & $(0.04)$ & $(0.04)$ \\
& -0.008 & -0.002 \\
Urban & $(0.005)$ & $(0.004)$ \\
& 0.03 & 0.08 \\
Population in 1,000 & $(0.1)$ & $(0.09)$ \\
Distance border & $0.0000008^{* *}$ & -0.0000002 \\
& $(0.0000003)$ & $(0.0000003)$ \\
Violent events & $-0.02^{*}$ & -0.008 \\
& $(0.01)$ & $(0.008)$ \\
& 0.009 & $0.03^{* *}$ \\
Observations & $(0.02)$ & $(0.02)$ \\
Mean Outcome & 74 & 74 \\
R Squared & 0.388 & 0.212 \\
\hline Standard errors & 0.832 & 0.741 \\
\hline
\end{tabular}

Standard errors in parentheses

District fixed effects and control variables included in all specifications.

${ }^{*} p<0.1,{ }^{* *} p<0.05,{ }^{* * *} p<0.01$ 
Table 3.8: Replacing Refugee Levels with an Instrumental Variable, Two-Stage Least Squares (2SLS) Models, 2002-2010 (Consumption and Health Service Provision)

\begin{tabular}{|c|c|c|c|c|c|c|}
\hline & $\begin{array}{c}(1) \\
\log (\text { Consumption })\end{array}$ & $\begin{array}{c}(2) \\
\text { First stage }\end{array}$ & $\begin{array}{c}(3) \\
\text { Gov. health }\end{array}$ & $\begin{array}{c}(4) \\
\text { First stage }\end{array}$ & $\begin{array}{l}(5) \\
\text { Priv. health }\end{array}$ & $\begin{array}{c}(6) \\
\text { First stage }\end{array}$ \\
\hline Refugees per 1,000 & $\begin{array}{c}0.003^{* * *} \\
(0.001)\end{array}$ & & $\begin{array}{c}-0.0003 \\
(0.002)\end{array}$ & & $\begin{array}{c}-0.006^{* *} \\
(0.003)\end{array}$ & \\
\hline Wage*Refugees per 1,000 & $\begin{array}{l}-0.002^{*} \\
(0.0009)\end{array}$ & & & & & \\
\hline Self-employed*Refugees per 1,000 & $\begin{array}{l}-0.002 \\
(0.001)\end{array}$ & & & & & \\
\hline Property*Refugees per 1,000 & $\begin{array}{c}0.007 \\
(0.006)\end{array}$ & & & & & \\
\hline Transfers*Refugees per 1,000 & $\begin{array}{c}-0.006^{* * *} \\
(0.001)\end{array}$ & & & & & \\
\hline Instrumental variable & & $\begin{array}{c}0.129^{* * *} \\
(0.004)\end{array}$ & & $\begin{array}{l}0.1^{* * *} \\
(0.009)\end{array}$ & & $\begin{array}{l}0.1^{* * *} \\
(0.009)\end{array}$ \\
\hline Wage*IV & & $\begin{array}{c}0.215^{* * *} \\
(0.003)\end{array}$ & & & & \\
\hline Self-employed*IV & & $\begin{array}{c}0.243^{* * *} \\
(0.011)\end{array}$ & & & & \\
\hline Property*IV & & $\begin{array}{c}0.386^{* * *} \\
(0.087)\end{array}$ & & & & \\
\hline Transfers*IV & & $\begin{array}{c}0.222^{* * * *} \\
(0.011)\end{array}$ & & & & \\
\hline Year $=2005$ & $\begin{array}{l}0.1^{* * * *} \\
(0.02)\end{array}$ & $\begin{array}{c}0.2^{*} \\
(0.09)\end{array}$ & $\begin{array}{l}0.04^{*} \\
(0.02)\end{array}$ & $\begin{array}{c}0.2 \\
(0.3)\end{array}$ & $\begin{array}{l}0.2^{* * * *} \\
(0.04)\end{array}$ & $\begin{array}{c}0.3 \\
(0.3)\end{array}$ \\
\hline Year $=2010$ & $\begin{array}{l}0.4^{* * *} \\
(0.02)\end{array}$ & $\begin{array}{l}0.6^{* * *} \\
(0.06)\end{array}$ & $\begin{array}{r}0.07^{* *} \\
(0.03)\end{array}$ & $\begin{array}{c}0.6^{* * *} \\
(0.2)\end{array}$ & $\begin{array}{l}0.1^{* * *} \\
(0.05)\end{array}$ & $\begin{array}{c}0.6^{* * *} \\
(0.2)\end{array}$ \\
\hline Observations & 10609 & 10609 & $\begin{array}{l}1126 \\
0.0879\end{array}$ & 1126 & 1080 & 1080 \\
\hline $\begin{array}{l}\text { Mean outcome } \\
\text { Adj. R Squared }\end{array}$ & $\begin{array}{l}10.64 \\
0.328\end{array}$ & 0.959 & $\begin{array}{l}0.0879 \\
0.0208\end{array}$ & 0.958 & $\begin{array}{l}0.337 \\
0.144\end{array}$ & 0.958 \\
\hline F Statistic & 94.64 & 599.6 & 2.373 & 75.20 & 9.128 & 65.41 \\
\hline
\end{tabular}

Robust standard errors in parentheses. District fixed effects and control variables are included in all specifications.

Note that in column 2 first stages for the instrument and the interaction terms have been combined.

${ }^{*} p<0.1,{ }^{* *} p<0.05,{ }^{* * *} p<0.01$ 
Table 3.9: Replacing Refugee Levels with an Instrumental Variable, Two-Stage Least Squares (2SLS) Models, 2002-2010 (Primary School Provision)

\begin{tabular}{lcccc}
\hline & $(1)$ & $(2)$ & $(3)$ & $(4)$ \\
& Gov. school & First stage & Priv. school & First stage \\
\hline Refugees per 1,000 & 0.003 & & $0.006^{* * *}$ & \\
& $(0.003)$ & & $(0.002)$ & \\
Instrumental variable & & $0.1^{* * *}$ & & $0.1^{* * *}$ \\
& & $(0.009)$ & & $(0.008)$ \\
Year=2005 & $0.1^{* * *}$ & 0.2 & 0.03 & 0.08 \\
& $(0.04)$ & $(0.3)$ & $(0.04)$ & $(0.3)$ \\
Year=2010 & $0.2^{* * *}$ & $0.6^{* * *}$ & $0.1^{* * *}$ & $0.6^{* * *}$ \\
& $(0.05)$ & $(0.2)$ & $(0.05)$ & $(0.2)$ \\
\hline Observations & 1124 & 1124 & 990 & 990 \\
Mean outcome & 0.384 & & 0.348 & \\
Adj. R Squared & 0.0375 & 0.958 & 0.146 & 0.960 \\
F Statistic & 2.807 & 75.19 & 16.63 & 71.50 \\
\hline Robust standard errors in parentheses. & &
\end{tabular}

Robust standard errors in parentheses.

District fixed effects and control variables are included in all specifications. ${ }^{*} p<0.1,{ }^{* *} p<0.05,{ }^{* * *} p<0.01$ 
Table 3.10: Replacing Refugee Levels with an Instrumental Variable, Two-Stage Least Squares (2SLS) Models, 2002-2010 (Households' Perceptions)

\begin{tabular}{lcccc}
\hline & $(1)$ & $(2)$ & $(3)$ & $(4)$ \\
& Living conditions & First stage & Ethnic identity & First stage \\
\hline Instrumental variable & & $0.1^{* * *}$ & & $0.1^{* * *}$ \\
& & $(0.004)$ & & $(0.004)$ \\
Refugees per 1,000 & -0.005 & & $0.005^{*}$ & \\
& $(0.003)$ & & $(0.003)$ & \\
Year=2005 & 0.005 & -0.1 & $-0.05^{* *}$ & -0.2 \\
& $(0.02)$ & $(0.2)$ & $(0.02)$ & $(0.2)$ \\
Year=2010 & $0.05^{*}$ & -0.1 & $0.07^{* * *}$ & -0.1 \\
& $(0.03)$ & $(0.1)$ & $(0.03)$ & $(0.1)$ \\
Log(mean light) & $-0.009^{* *}$ & $-0.02^{* *}$ & -0.002 & $-0.03^{* * *}$ \\
& $(0.004)$ & $(0.010)$ & $(0.003)$ & $(0.010)$ \\
Urban & -0.01 & 0.07 & 0.01 & 0.07 \\
& $(0.02)$ & $(0.08)$ & $(0.02)$ & $(0.08)$ \\
Population in 1,000 & $0.0006^{* *}$ & $0.01^{* * *}$ & -0.0002 & $0.01^{* * *}$ \\
& $(0.0002)$ & $(0.001)$ & $(0.0002)$ & $(0.001)$ \\
Violent events & 0.008 & $-1.1^{* * *}$ & $0.03^{*}$ & $-1.2^{* * *}$ \\
& $(0.02)$ & $(0.1)$ & $(0.01)$ & $(0.1)$ \\
\hline Observations & 3741 & 3741 & 3608 & 3608 \\
Mean Outcome & 0.400 & & 0.233 & \\
Adj. R Squared & 0.116 & 0.962 & 0.0379 & 0.964 \\
F Statistic & 16.48 & 2171.5 & 4.698 & 1964.2 \\
\hline Robust standard errors in parentheses & & &
\end{tabular}

Robust standard errors in parentheses

District fixed effects and control variables are included in all specifications.

${ }^{*} p<0.1,{ }^{* *} p<0.05,{ }^{* * *} p<0.01$ 


\title{
4 Missing Men: Differential Effects of War and Socialism on Female Labour Force Participation in Vietnam
}

\begin{abstract}
We investigate the effect of the Vietnam War and the socialist regime in the Northern part of the country on female labour force participation. We differentiate the effect across birth cohorts, thus comparing immediate and long-term impacts. After presenting a theoretical model implying effects due to the role played by the 'added workers' and cultural change, we use data from three national household censuses in 1989, 1999, and 2009 to estimate probit models of determinants of women's choice to enter the labour market. Proxying war intensity with the provincial share of female population after the war, the effect of 'missing men' on the work status of women is found to be positive and significant for those cohorts directly affected by the war. For those cohorts entering working age after the end of the conflict, the effect is still positive but smaller and in some specifications insignificant. Living in the Northern part of the country increases the likelihood of a woman working by around eleven percentage points, suggesting a larger and more persistent effect of socialism on female labour force participation.
\end{abstract}

\subsection{Introduction}

In general, changing the way societies define the roles of women and men and their position in the household and the labour market is a very slow process (see World Bank 2011b, Gaddis and Klasen 2014, and Fernàndez 2007 for a discussion). It depends on many factors, among others on urbanisation, education, and the political context. However, violence can act as an external shock: In times of war, it is mainly men who leave to fight and might be killed. Consequently, women take over positions and tasks that would have been unusual and partly unacceptable before - they become 'replacement workers' and heads of household. At some point, however, the men will return and a next generation will grow up to take over responsibility in the family and the community and the question arises whether women remain in their newly gained positions or whether the society returns to the pre-conflict status.

In this chapter, we examine this dynamic for a conflict with very high military mobilisation, the Vietnam War. In particular, we focus on how wartime mobilisation and destruction has had persistent effects on the labour force participation of Vietnamese women. As the conflict took place between 1965 - $^{-} 75$, it is possible to differentiate short-term from long-term and direct from indirect effects. Vietnam also provides an interesting case study as we can directly compare the impact of socialist ideology on female labour force participation which affected the North of Vietnam for much longer and more persistently with the effect of wartime mobilisation and destruction.

This is joint work with Stephan Klasen. 
We analyse these questions using a theoretical model of structural change and econometric analyses where we identify the effect of the conflict with the share of female population shortly after the war, and the effect of socialism with the length of pre-economic reform socialist rule in Vietnam. Applying three waves of national censuses for the years 1989, 1999, and 2009, we find that women who were of working age during the conflict are significantly more likely to work in areas that were more heavily affected by fighting. For younger women, the effect of 'missing men' on their decision to work is still visible but much smaller. However, the impact of living under the socialist system of North Vietnam appears to be more influential and persistent than the one of wartime mobilisation.

In the next section, we summarise the literature that this work contributes to. To the best of our knowledge, this is the first study to look at the long-term consequences of war on the labour force status of women and thus, indirectly, culture and gender roles, in a developing country. We are also the first ones to include a comparison with the impact of a political system such as socialism. In our theoretical model in section 4.3, we determine the labour market participation of women by the political context and the impact of war through the channels of changing values and economic necessities. After giving some background information in section 4.4, we describe our econometric approach and our results before section 4.6 concludes.

\subsection{Literature}

This work contributes to three strands of literature: The determinants of female labour force participation in general, as well as the 'added worker' hypothesis and cultural change more specifically. All of these are also combined in a small literature analysing the impact of war on women, in which most of the articles deal with the consequences of World War II (WWII), particularly in the United States of America (USA).

At the country level, the relationship between economic development and female labour force participation is often found to follow a U shape (Goldin 1994, Mammen and Paxson 2000). The narrative prevalent in the literature posits that, in very poor societies, every household member has to work to contribute to the common income. Furthermore, employment is often in agriculture which means that women stay close to their homes and can easily look after their children while working. As economies grow, they are often industrialised which makes combining market and housework more complicated. At the same time, men earn enough to provide for their families so that the cultural norm for women becomes to stay at home. As countries become even richer, education - also of women - increases so that it becomes costlier for them to stay at home. In addition, fertility decreases and women increasingly enter the 
workforce. While this 'feminisation U-hypothesis' is intuitively appealing and can be found in cross-country studies, panel data have produced mixed results and there appears to be a great persistence in female labour force participation differences between countries, suggesting that more deep-seated cultural and institutional factors are very important (Cagatay and Özler 1995, Gaddis and Klasen 2014, and Tam 2011).

When trying to explain these cross-country differences in women's participation in the labour market, a range of factors have been found to play a role. The historical structure of the economy can either include or exclude women from labour markets. If, for example, the region was historically more suitable for the usage of a plough requiring more strength and less manual work, women are more likely to be confined to housework (Boserup 1970, Alesina et al. 2011a, and Alesina et al. 2013). Similarly, economies that heavily rely on the extraction of mineral resources mainly depend on male workers (Ross 2008).

Another aspect that operates in the rather long run are religious beliefs, which can have a differentiated effect on the intra-family division of labour (Amin and Alam 2008 and Lehrer 1995). Specifically, Protestantism has been found to foster work ethics in general (Weber 1905 and Feldmann 2007) while overall, all religions are apparently discouraging female employment (Guiso et al. 2003). Specifically, more religious women haven been shown to react less to family benefits aiming at an increase in working mothers than more secular ones (Jaeger 2010). Closely linked, cultural values are generally strong predictors of women's working behaviour and have a lasting impact: Attitudes towards working women are developed during youth, influenced by parental education and religious affiliation, and are then reflected in adult daughters' or daughter-in-laws' working decisions (Farré and Vella 2013, Fernàndez et al. 2004, and Fortin 2005). A range of studies finds that culture is not only important within a country or context (e.g., Clark et al. 1991 and Kevane and Wydick 2001) but is actually a mobile factor, that people take with them when moving across countries. First- and second-generation immigrants in the USA still reflect attitudes and behaviour that are linked to their country of origin (Antecol 2000, Fernàndez 2007, and Fernàndez and Fogli 2009).

In the shorter run, policy makers have the possibility to set incentives, e.g., in the different ways of taxing married couples' incomes or regarding issues such as child care, paid parental leave, child benefits, or the organisation of a school day (Gustafsson 1992, Gustafsson et al. 1996, Priebe 2010, and Alesina et al. 2011b). Especially in the case of the East Asian Tigers, basing their fast growth on strategic openness of the export sector, the inclusion of women as additional workforce and human capital has been found to be crucial for promoting growth as well as female economic participation (Klasen and Lamanna 2009, Seguino 2000). 
Socialist countries represent an extreme example of a policy environment that particularly encourages female labour force participation. This is the case for both the former socialist states of Eastern Europe and the former Soviet Union as well as for some present-day socialist states such as Cuba. Women's labour force participation in these socialist regimes was or is promoted through high investment in female education and generous provision of state-provided child care and other family support measures. While the descriptive statistic of higher rates of working women in socialist states as compared to other political systems is undisputed, the degree to which it stems from an ideological commitment to gender equality or from a necessity of increased labour due to inefficient production processes is controversially discussed (e.g., Klasen 1994 and Kornai 1992).

At the micro level, female education and the economic situation of the household play important roles (Fortin 2005, Klasen and Pieters 2015). Going back to the seminal works by Mincer (1962), Ashenfelter (1980), and Lundberg (1985), the decision of women to enter the labour market or to increase their labour supply when their husbands become unemployed or earn less has been termed the 'added-worker effect'. This means of consumption smoothing has been found to hold in different contexts, e.g., in Argentina, Mexico, and Europe (McKenzie 2004, Parker and Skoufias 2004, Prieto-Rodrìguez and Rodrìguez-Gutiérrez 2003). Bhalotra and Umaña-Aponte (2010) point out that many households in developing countries do not have access to mechanisms of coping with income shortages such as insurance, credit, or social security. Especially in times of macroeconomic crises they often lack assets to sell or networks to fall back on. As a result, households use the one asset they control, their labour. Bhalotra and Umaña-Aponte (2010) find this relationship to be present in Latin American and Asian countries, while African women have the tendency of falling out of employment during recession. They explain these heterogeneous results with different family structures and varying structures of the economies.

Violent conflicts are extreme cases of exogenous shocks generating the 'added worker effect'. The first studies analysing the effect of conflict on women's roles dealt with the impact of World War II (WWII). As Goldin (1991) and Clark and Summers (1982) show for the USA, after female labour force participation had increased from 28 per cent to 34 per cent between 1940 and 1945, more than half of the women drawn into the labour force by the war left again by 1950, leaving the direct impact on the war generation to be moderate. The authors explain the first rapid increase with both a labour demand shock following the mobilisation of men and the necessity to replace their forgone earnings at the household level. When the men returned from war, preference was given to them when assigning jobs. Akbulut-Yuksel et al. (2011) find similar results for the German 'rubble women' who were drawn into the labour force by post-war 
mandatory employment laws. They do not find evidence for any long-term effects on daughters and grand-daughters of the war generation. Along the same line, Ridd and Callaway (1987) caution that gender roles are modified only temporarily for the duration of conflict, but often return to the pre-conflict norm when conflict ends. In contrast to this, Fernàndez et al. (2004) find an impact of WWII on post-war generations' working status. They argue that due to the formation of preferences and norms during childhood (see also section 4.3), wives of men whose mothers worked are themselves significantly more likely to work. Following Acemoglu et al. (2004), they use mobilisation rates of US American men as an instrument for female labour force participation, as they are considered to represent an exogenous variation in female labour supply.

Looking at developing countries, Schindler (2010) and Brück and Schindler (2009, 2011) analyse the consequences of the Rwandan genocide. The loss of men and children is visible both in women's fertility decisions where a clear 'replacement effect' is found as well as in the new roles that women take in private and public life. Interestingly, this applies mainly to widows and female household heads while young women appear to conform especially strongly with traditional gender roles, arguably in order to increase their chances on the marriage market. In line with this, an emancipatory effect cannot be identified within male-headed households. In El Salvador, Nepal, Tajikistan, Peru, Sri Lanka, and Sierra Leone, women also acquired new skills and became the breadwinners of the household during civil wars replacing men who were either dead, fighting or absent (Ibàñez 2001, Menon and van der Meulen Rodgers 2013, Shemyakina 2015, and Wood 2008). All of these conflicts, however, are too recent to make a statement about long-term effects.

Summarising, while there is a considerable literature on determinants of female labour force participation and differences in this regard between both countries and households, most of these works focus on developed countries or cross-country analyses. This paper thus contributes to the existing research by including the 'added worker' perspective, the role of the political framework as well as a long-term viewpoint in developing countries.

\subsection{Model}

The simple theoretical framework developed in this chapter aims at modelling the combined effect of wartime mobilisation and socialism on female labour force participation in Vietnam. Both the necessity of the wartime mobilisation of men taking away the breadwinner of the family as well as the political influence on peoples' values and the role of women for the working decisions of females are taken into account. 
The static neoclassical model of labour force participation suggests that an individual will maximise her utility by choosing a specific combination of leisure and consumption. In order to finance the consumption, the person has to work in the market at a particular wage rate and at the expense of leisure. This way of modelling implies that time out of work is a result of choices. In many developing countries, however, this is not likely to fit the reality of the population. The seminal paper modelling unemployment as a constraint rather than a choice, thus recognising its character as a disequilibrium, is Ashenfelter (1980). When one household member is unemployed, i.e., they face the binding constraint of not being able to sell the desired number of hours on the labour market, the other household members factor this constraint into their decision. Through both the income and the substitution effect, in the case of an exogenous spell of unemployment for the husband, Ashenfelter's model predicts that the wife would seek to work more outside the house. This is the so-called 'added worker effect' also described in section 4.2. During conflict, the man is rather absent than unemployed. Yet, his reduced income and the assumption that the other household members take this into account when making there working decisions is equivalent to the case of unemployment.

While Ashenfelter's model considers an unspecified household size of $n$ members, we simplify the approach by only taking into account $n=2$, i.e., husband and wife. Together, they act in a way that maximises the household's utility at time $t, U_{H H}\left(C_{t}, I_{t}, S_{t}\right)$. As in the neoclassical models, the utility depends on the household's consumption, $C_{t}$. Additionally, the social stigma assigned to a woman working, $S_{t}$, results from the society's perception of the woman's role being one of housewife and mother. This social stigma is rarely taken into account (exceptions being Hazan and Maoz 2002, Fernàndez et al. 2004, Fernàndez 2013, and Fogli and Veldkamp 2011) but it is crucial to understand the dynamics of female labour force participation (FLFP). $I_{t}$ is an indicator variable equal to one if the wife works. One work closely related to the way of modelling presented here is Hazan and Maoz (2002) who proxy the stigma attached to a woman being active in the labour market today by the previous generation's share of working women. In Fernàndez et al. (2004), the specific channel from one generation to the next is the share of men's mothers working in the previous period, making it more likely that men's wives today will take up employment. Fernàndez (2013) models cultural change as the result of a rational, intergenerational learning process based on the public beliefs towards a woman's role in society represented by the share of women working in the past and private information about the costs of working. Fogli and Veldkamp (2011) model the learning process in the form of geographical clusters where women learn from their older female neighbours who worked previously, a higher share of neighbours working in the past having an encouraging effect on young women at present. 
What all of these models have in common and what will also be applied here is that cultural perceptions of the role of women play a role when households decide whether a woman should work and that this social rule is reflected in how many females worked in the past.

We add to this literature by specifically combining the 'added worker' and the cultural change models, assuming that perceptions about the role of women today are shaped by economic necessities in the past. Another augmentation is the inclusion of political measures or ideology into the model. Both these factors are expected to have the ability to 'fast forward' social change.

Specifically, the model is designed as an overlapping generations model, with couples working in period $t$ and consuming in period $t+1$. With

$$
\operatorname{Max}_{I_{t}} U_{H H}\left(C_{H H, t+1}, I_{t}, S_{t}\right)=\log \left(C_{H H, t+1}\right)-I_{t} * S_{t},
$$

the social stigma only affects the household's utility, if $I_{t}=1$, i.e., if the wife works. As the consumption is included in its logarithmic form, it has decreasing marginal returns with regard to utility, i.e., additional consumption becomes less important at higher levels. Furthermore, $U_{H H}$ is separable, so that the utility of consumption is independent from the stigma. The couple's consumption in $t+1$ is made up of the husband's income, $y_{t}^{h}$, and - if she works - the wife's income, $y_{t}^{w}$ in period $t$ and multiplied with the interest rate:

$$
C_{H H, t+1}=\left(y_{t}^{h}+I_{t} * y_{t}^{w}\right) *(1+r) .
$$

Consequently, the wife will work in the market if and only if the additional consumption in the future outweigh the contemporaneous social stigma, i.e., if the household's utility is at least as high when she works as when she does not work:

$I_{t}=1 \mathrm{iff}$

$$
U_{H H}\left(C_{H H, t+1}, S_{t}\right) \geq U_{H H}\left(C_{H H, t+1}, 0\right),
$$

or

$$
\log \left[\left(y_{t}^{h}+y_{t}^{w}\right) *(1+r)\right]-S_{t} \geq \log \left[y_{t}^{h} *(1+r)\right],
$$

which reduces to

$$
\log \left(1+\frac{y_{t}^{w}}{y_{t}^{h}}\right) \geq S_{t}
$$

so that the wife works either if her own wage is so high that it offsets the social stigma or if 
her husband's wage is low enough to have the same effect. As can be seen, $S_{t}$ is taken to be statically exogenous and constant. However, dynamically, it is endogenous and depends on the situation in the period before, i.e., on the share of the women who participated in the labour market in the previous generation, $P_{t-1}\left(0 \leq P_{t-1} \leq 1\right)$. Specifically, the stigma is assumed to be smaller the more women worked in period $t$-1, as they are considered to be a proxy for past beliefs and to represent a social learning process. ${ }^{52}$ Furthermore, a country-wide 'crisis and policy effect', $E_{t}$, is included, that weakens the stigma in the current period (for example because the absence of men makes it generally more necessary for women to work) but has the potential to be reduced in the following period, thus allowing the stigma to unfold again.

$$
S_{t}=S_{t}\left(P_{t-1}, E_{t}\right)=D-\beta\left(P_{t-1}+E_{t}\right),
$$

with $D$ denoting a random variable with the cumulative density function $\mathrm{F}(\mathrm{D}), \beta>0$, and $0 \leq C_{t} \leq 1$. In the case of Vietnam, $E_{t}$ comprises the direct impact of war destruction as well as the political context, i.e., the duration of socialism. Depending on the household's $D$ the stigma can even turn out to be positive, e.g., in socialism a family could gain utility when the woman works, too.

Plugging equation 4.6 into equation 4.5 shows that a married woman will work iff

$$
D \leq \log \left[1+\frac{y_{t}^{w}}{y_{t}^{h}}\right]+\beta\left(P_{t-1}+E_{t}\right)
$$

Consequently, the total number of women working in $t$ can be denoted as a function of the previous period's female labour force participation rate (FLFPR) and the current economic and political situation:

$$
P_{t}=F\left(y_{t}^{w}, y_{t}^{h}, P_{t-1}, E_{t}\right)
$$

Thus, the static increase of FLFP due to a general slump in male income would persist dynamically in 'fast-forwarding' cultural change because of a drastically reduced stigma $S_{t}$ in the following periods. A fall back into old gender roles after a resurgence of male earnings would be possible to the extent that $E_{t}$ would return to its pre-crisis level but limited by the lasting effect of a higher $P_{t-1}$.

\footnotetext{
${ }^{52}$ See also above for works following this approach.
} 


\subsection{Background}

The traditional Vietnamese society during the French colonial rule ${ }^{53}$ could be characterised as rather patriarchal, authoritarian, and reliant on subsistence agriculture, where women's activities were confined to the household and the family's plot (Bunck 1997). In the course of the 1930s, the communist nationalist movement linked women's rights and the struggle against colonialism. Feminism was seen as a theme cutting across classes, thus increasing the base for mobilisation, as women would participate in the revolution on a basis of equality with men. After independence from the French in 1954, the country was divided at the $17^{\text {th }}$ parallel, separating the socialist North ruled by Ho Chi Minh from the pro-Western South, governed by Diem. In the Northern part of the country, the government of the Democratic Republic of Vietnam codified in their 1960 constitution that 'women enjoy equal rights with men in all spheres of political, economic, cultural, social, and domestic life' (Turley 1972).

While already the fight for independence (1946-'54) brought turbulence over the country, the Vietnam (or American) War (1965-'75) induced massive changes to its social, economic, and political structure. In 1946, women played only a minor role in political life and their labour force participation was very low. Although by 1965, their public visibility had increased slightly, a major shift was seen by 1971/ '72 (Werner 1981). In the whole country, increasing numbers of men entered the armed forces from the mid-1960s onwards, resulting in a severe shortage of male labour. Many of the young men who were drafted never returned. Compared to non-war mortality, the risk of dying for males between the age of 15 and 29 was more than seven times higher, at age 30 to 44 it was still two and a half times greater. During the years 1965 - $^{\circ} 75$, mortality among all Vietnamese men older than 15 was twice as high as it would have been expected in times of peace - for women the likelihood of dying was 35 to 39 per cent higher (Hirschman et al. 1995). It is estimated that the conflict made around 1,000,000 Vietnamese women widows (Stewart 1993). Consequently, women entered the workforce in large numbers and in all sectors, but especially in agriculture where the share of women among all workers increased from 60 to 70 per cent in 1966 to 80 to 90 per cent in 1971 (Turley 1972).

In the North, it was the combination of war necessities and the socialist restructuring of the economy which is seen to have made the increase on female labour force participation specifically lasting (Goodkind 1995 and Werner 1981). In line with the political agenda but also faced with the severe shortage of male workers, policies were implemented to draw women into the workforce, such as nurseries, paid parental leave and equal pay as men's (Einhorn 1995). At the same time, family farms were converted into state cooperatives which were often led and

\footnotetext{
${ }^{53}$ French Indochina, i.e., the French colonial rule in Southeast Asia lasted from 1887 to 1954.
} 
administered by women, leading to a 'feminisation of agriculture' with women performing tasks that would have previously been thought unfit for them (Bunck 1997). In fact, this was part of a political calculation with party leaders being convinced that war-time mobilisation of women could alter values, self-concepts and perceptions of women's role sufficiently to make it unlikely for them to reverse after war, which would be useful with regard to reconstruction (Turley 1972). In fact, when looking at the World Values Survey for Vietnam in 2001 (World Values Survey Association 2001), a significantly lower share of the population in the North than in the South (41.3 vs. 50.6 per cent) would agree with the statement 'when jobs are scarce men should have more right to a job than women' even a long time after reunification.

With the defeat of the South and reunification at the end of the war, the whole of Vietnam became a socialist Republic in 1976. However, in the course of the Doi Moi reforms of 1986, it underwent a massive change towards a 'market-oriented socialist economy under state guidance', leading to high economic growth rates throughout the 1990s and 2000s. This meant a re-privatisation of ownership, an abandonment of central planning and allowing the farmers to sell excess production (Beresford 2008 and Corfield 2008). Following privatisation, the state laid off around 900,000 workers and closed thousands of state enterprises. Of the people losing their jobs, around 60 per cent were women, yet many of them were absorbed by the rapidly growing private sector (Bunck 1997). Another challenge to female employment were the returning men who also required jobs. The political stance on the issue changed towards the idealisation of the family and the woman's role within it as opposed to new technologies being the domain of men. This also led to policies such as child care and parental leave being severely cut. Consequently, the advances made by women during the war were partly reversed and partly diverted into high occupational segregation (Goodkind 1995, Tuyen 1999, and Werner 1981).

Thus, after approximately fifty years of increases in female labour force participation due to conflict and political ideology, at a least a partial turnaround has been observable over the last twenty years. However, a quantification of the two positive effects as well as an analysis of their development over time offers valuable insights.

\subsection{Empirical Analysis}

Based on the theoretical model in section 4.3 and the historical background described in section 4.4, we will empirically test the following hypotheses in this section: Women living in provinces that were more severely hit by the Vietnam War should be significantly more likely to take up work than those living in more peaceful areas. Specifically, the effect should be more pronounced for the birth cohorts directly affected by the war, i.e., those of working age in the 1965- ${ }^{\circ} 75$ period. 
This reasoning is based on the 'added worker' effect in equation 4.5 as husband's income, $y_{t}^{h}$, equals zero (or is very small) when the husband has been drafted to fight, thus overruling stigma $S_{t}$. At the same time, $S_{t}$ is reduced because of a high 'crisis term' $E_{t} .{ }^{54}$ For the following generations, and thus visible in the overall effect, the impact of war is passed on through cultural change as depicted in equations 4.5 and 4.8. Independent from the Vietnam War, the longer exposure to socialism in the North of the country (the Democratic Republic of Vietnam) should increase the FLFPR relative to the Southern part of the country, according to equation 4.7, as $E_{t}$ is permanently higher.

\subsubsection{Data}

The dataset applied is a combination of the Vietnamese Population and Housing Censuses of the years 1989, 1999, and 2009 (Vietnamese General Statistics Office 2009). It is an ever-married, all-female sample at working age, i.e., aged 15 to 60 , comprising 3,154,587 women in 47 provinces.

Table 4.1: Descriptive Statistics

\begin{tabular}{|c|c|c|c|c|c|}
\hline & Min. & Max. & Mean & SD & $\mathrm{N}$ \\
\hline Working & 0.00 & 1.00 & 0.85 & 0.36 & 3701971 \\
\hline Percent female population in 1979 & 44.25 & 53.64 & 51.39 & 1.33 & 3701971 \\
\hline Total U.S. bombs, missiles, and rockets per km2 & 0.01 & 335.47 & 25.15 & 41.37 & 3701971 \\
\hline Age & 15.00 & 60.00 & 39.46 & 10.34 & 3701971 \\
\hline Less than primary completed & 0.00 & 1.00 & 0.38 & 0.48 & 3699562 \\
\hline Primary completed & 0.00 & 1.00 & 0.48 & 0.50 & 3699562 \\
\hline Secondary completed & 0.00 & 1.00 & 0.10 & 0.30 & 3699562 \\
\hline University completed & 0.00 & 1.00 & 0.04 & 0.20 & 3699562 \\
\hline Husband working & 0.00 & 1.00 & 0.81 & 0.39 & 3698409 \\
\hline Husband less than primary completed & 0.00 & 1.00 & 0.30 & 0.46 & 3219655 \\
\hline Husband primary completed & 0.00 & 1.00 & 0.53 & 0.50 & 3219655 \\
\hline Husband secondary completed & 0.00 & 1.00 & 0.11 & 0.32 & 3219655 \\
\hline Husband university completed & 0.00 & 1.00 & 0.05 & 0.22 & 3219655 \\
\hline Husband absent & 0.00 & 1.00 & 0.08 & 0.28 & 3701971 \\
\hline No. of children under 5 & 0.00 & 6.00 & 0.35 & 0.61 & 3701971 \\
\hline Household migrated in past 5 years & 0.00 & 1.00 & 0.02 & 0.15 & 3700087 \\
\hline Urban & 0.00 & 1.00 & 0.30 & 0.46 & 3701971 \\
\hline Province FLFPR & 0.46 & 0.97 & 0.85 & 0.11 & 3701971 \\
\hline Change in population density, 1990-2001 & 2.23 & 670.98 & 86.04 & 148.48 & 3701971 \\
\hline Consumption expenditures p.c., 1992/3 (in 1998 Dong) & 1407.42 & 5453.99 & 2586.94 & 791.36 & 3701971 \\
\hline Proportion born in current village, $1997 / 8$ & 0.00 & 1.00 & 0.72 & 0.22 & 3631847 \\
\hline Province literacy rate, 1999 & 0.55 & 0.97 & 0.88 & 0.08 & 3701971 \\
\hline Proportion of HH with access to electricity, 1999 & 0.30 & 1.00 & 0.73 & 0.20 & 3701971 \\
\hline Proportion of land cultivated, 1999 & 0.00 & 54.57 & 11.30 & 12.48 & 3701971 \\
\hline Southern province & 0.00 & 1.00 & 0.47 & 0.50 & 3701971 \\
\hline Year $=1989$ & 0.00 & 1.00 & 0.11 & 0.31 & 3701971 \\
\hline Year $=1999$ & 0.00 & 1.00 & 0.11 & 0.32 & 3701971 \\
\hline Year $=2009$ & 0.00 & 1.00 & 0.78 & 0.42 & 3701971 \\
\hline
\end{tabular}

Table 4.1 shows the descriptive statistics of the sample. ${ }^{55}$ The outcome variable is a binary variable taking the value of 1 if the woman is part of the labour force and the value of 0 if she is

\footnotetext{
${ }^{54} \mathrm{As}$ we do not have any information whether or not the husband fought in war, we cannot distinguish these two channels empirically.

${ }^{55}$ For descriptive statistics by census wave, see the appendix.
} 
coded as 'inactive'. Specifically, a woman is considered to participate in the labour market if she is employed or self-employed and has worked for at least six out of the preceding twelve months (for at least one hour per day) or if she is unemployed but looking for work. ${ }^{56}$ As can be seen in Table C1, the FLFP is rather high in Vietnam; specifically, the average increased from 78 per cent in 1989 to 86 per cent in 2009. Overall, the vast majority of women in the sample (64.71 per cent) works in agriculture, fishing, and forestry, followed by wholesale and retail trade (11.89 per cent), manufacturing (8.19 per cent), and education (5.05 per cent). While most women work on their own account (58.69 per cent), another large share are unpaid family workers (23.31 per cent) or wage/ salary workers (17.78 per cent, half of which work in the private and public sector, respectively).

The main variable of interest is the share of female population at the province level in 1979, i.e., very shortly after the end of the Vietnam War (Vietnamese General Statistics Office 1982). ${ }^{57}$ The variable is taken from the report on the 1979 census and directly captures the outcome of the conflict of interest here, the absence of men. Although a large share of drafted men should have returned home by that time, it is still a proxy for the death rate and the gender bias therein mentioned in section 4.4. As such, it is used as a proxy for stigma $S_{t}$ in the model in section 4.3, as it influences both the 'crisis term' $E_{t}$ at the province level and indicates a very low (or zero) husband's income $y_{t}^{h}$, which in turn reduce the stigma. Figure 4.1 shows the spatial distribution of this variable.

An alternative measure of war intensity would be to use a measure of wartime fighting. Miguel and Roland (2011) use an indicator for the total number of U.S. bombs, missiles, and rockets dropped per $\mathrm{km}^{2}$ in 1965-' 75 to estimate the 'long-run impact of bombing Vietnam' on economic development. They do not find any effect on local poverty rates, consumption levels, infrastructure, literacy or population density still detectable in 2002. However, their indicator of physical destruction is not significantly correlated with our measure of human harm. ${ }^{58}$ This might be because men did not fight and were not killed by bombings close to where they were drafted and where their families lived. Thus, where bombing was heaviest might not be where men were missing. As what we wish to measure is the effect on the Vietnamese population, specifically on male mortality, the share of female population is a more direct indicator than the amount of ordnance dropped.

A considerable concern regarding our main variable of interest are spill-overs, e.g., through

\footnotetext{
${ }^{56}$ We choose this specification of the 'working' variable as it follows the definition of FLFP. Only 0.78 per cent of the women in our sample are unemployed. Dropping these observations does not change our results.

${ }^{57} \mathrm{We}$ are extremely grateful to Charles Hirschman for sharing this report.

${ }^{58}$ The bombing intensity indicator is also not significantly related to FLFPR.
} 


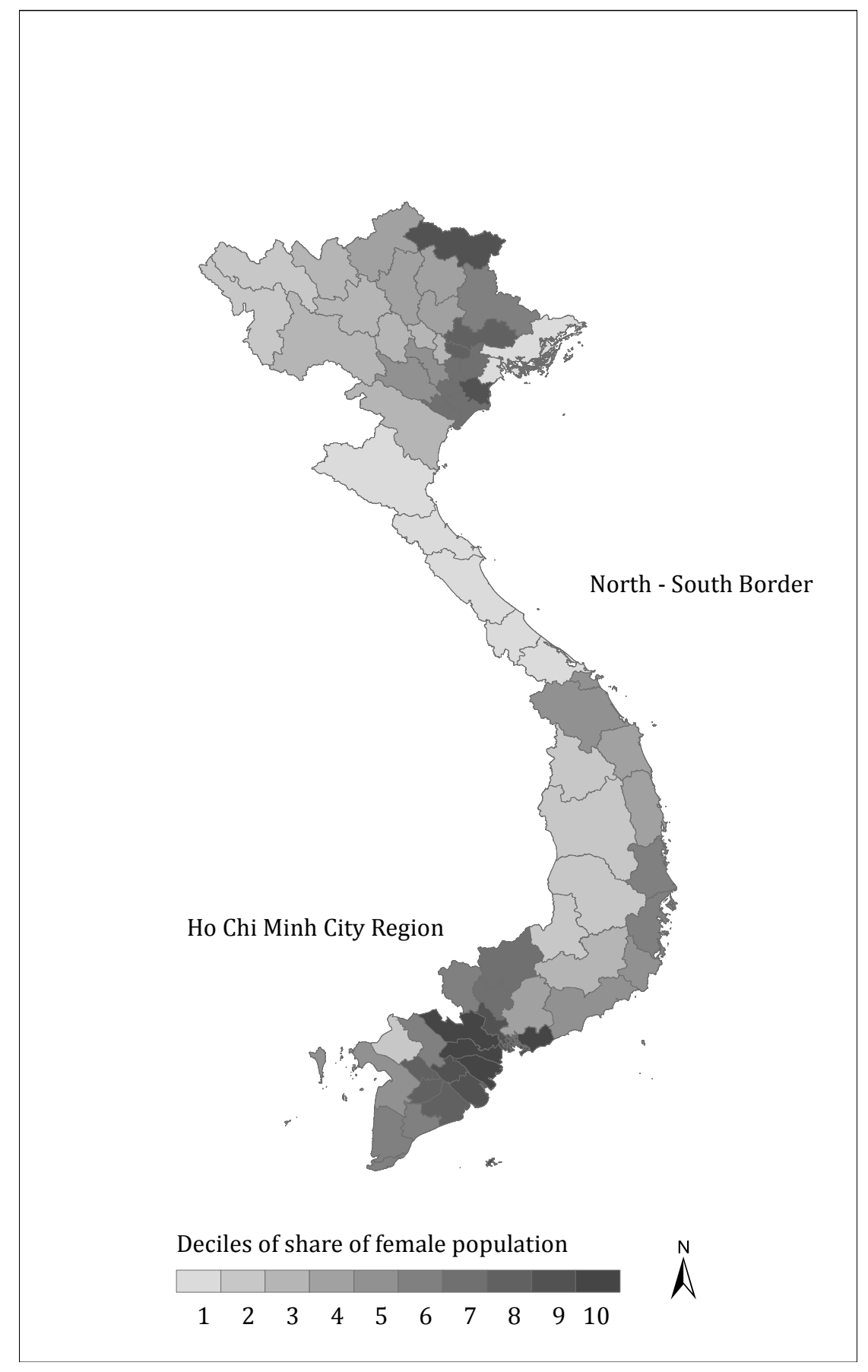

Figure 4.1: Share of Female Population by Province, 1979 
migration. While we carry out a robustness check averaging our conflict intensity indicator across three provinces (see section 4.5.4 below), we also include the proportion of the population born in the current village (province averages for the year 1997/8), the change in population density over the course of the 1990s (both taken from Miguel and Roland 2011) as well as the individual level variable whether the household migrated in the last five years to address this issue. Staying in the framework of cultural change, the issue of people moving to a region after the end of war should not dissolve the effect of conflict as long as the migrants form a minority that is too small to affect values. Should there be a bias from migration left, it would be downward, rendering our estimates to be lower bound effects.

In order to control for other (non-cultural) channels for the long-run effect of war intensity on FLFP, for example through increased reconstruction or industrialisation efforts, we include a number of further covariates at the province level. Namely, we use the average consumption expenditures per capita, the province literacy rate, the proportion of households with access to electricity, and the proportion of land cultivated as a proxy for the importance of the agricultural sector, which employs the majority of women (all time invariant, measured in the 1990s and taken from Miguel and Roland 2011).

Household level indicators following the general FLFP literature are also added to the estimation equation. Specific to our context is the variable 'husband absent', representing a possible transmission channel at the household level. It indicates that a woman has been married but her husband is not currently present in the household, e.g., because he migrated or because she is a widow or divorced. The province level FLFPR is not included in the model but reported here to give an impression of the general likelihood of women taking up work.

\subsubsection{Model and Findings}

Following the common specifications in the FLFP literature, we run a number of probit models, each of them with the current work status of the women in the sample as the dependent variable $\left(W_{i, t}\right)$. We also control for a number of individual, household, and province variables $\left(X_{i, t}\right)$ as described above in section 4.5.1 and include region and year fixed effects to control for unobserved heterogeneity ( $\alpha_{r}$ and $\delta_{t}$, respectively). As the variable of interest, the share of female population in 1979 (Share_Female S $_{\text {) }}$, is measured at the province level, standard errors are clustered at this level, too $\left(\epsilon_{p}\right)$. Thus, the estimation equation takes the form:

$$
W_{i, t}=\beta_{1} \text { Share_Female }_{p}+\beta_{2} X_{i, t}+\alpha_{r}+\delta_{t}+\epsilon_{p}
$$


In a second step, interaction terms of the conflict indicator with the birth cohort will be added in order to see if there is a distinct effect of conflict for different generations.

A reduced model estimation only including the share of female population as an explanatory variable of a woman's likelihood to work as well as region and year fixed effects is presented in Table 4.2, column 1. Average marginal effects are presented. It can be seen that, on average, a one percentage point increase in the share of female population in 1979 (approximately equivalent to one standard deviation) increases the likelihood of a woman being active in the labour market more than 15 years after the end of the war by around 1.4 percentage points. The effect is statistically significant at the 0.1 per cent level. In column 2 , control variables are added, which does not change the finding regarding the share of female population. The covariates included have the expected signs: Age follows an inverted U shape, while own education has a positive and husband's education a negative effect. A larger number of children below the age of five reduces a woman's propensity to work. Regarding the huge presence of women in the agricultural sector, the negative effect of living in urban centres is also not surprising and in line with the positive effect of the proportion of land cultivated.

In a second step, interaction effects of the share of female population with binary variables for birth cohorts are included in order to see if the effect differs from one generation to the next. One cohort represents women being born in the same decade between the 1920s and 1980s. As marginal effects in non-linear models are not straightforward to interpret (Ai and Norton 2003), they are not presented in a table but rather plotted in Figure 4.2.59 It can be seen that the marginal effect is positive and statistically significant for all cohorts except for those born in the 1920s, but that there is a decrease for younger age groups. The women born in the 1920s were already approaching the end of their working life (at least 45 years old) when the war started, thus it is possible that it did not affect them as much. Furthermore, their husbands were probably too old to be drafted to fight. When testing whether the change from one group to the next is statistically significant, only the marginal effect for those born in the 1950s and in the 1960s is different from the one for those born in the 1940s and 1950s, respectively. Thus, there are two groups: Women who were directly affected by the conflict during their working age react more strongly than women entering the labour force afterwards. This is in line with the anecdotal evidence presented in section $4.4 .^{60}$

Another explanation for the decreasing effects across cohorts, following for example Fogli and Veldkamp (2011), might be the diffusion of values and knowledge regarding working women

\footnotetext{
${ }^{59}$ Results displaying coefficients for the interaction terms rather than marginal effects are presented in appendix C2. Stata does not produce tables of average marginal effects for interaction terms as they cannot be interpreted. ${ }^{60}$ The 1950 s cohort forms their own group as they were partly affected and partly too young during the conflict.
} 
Table 4.2: Determinants of Women's Choice to Work, Probit Models, 1989-2009

\begin{tabular}{|c|c|c|c|}
\hline & $(1)$ & $(2)$ & $(3)$ \\
\hline Percent female population in 1979 & $\begin{array}{l}0.0144^{* * *} \\
(0.00399)\end{array}$ & $\begin{array}{l}0.0127^{* * *} \\
(0.00193)\end{array}$ & $\begin{array}{c}0.00914^{* * *} \\
(0.00277)\end{array}$ \\
\hline Age & & $\begin{array}{c}0.0239^{* * *} \\
(0.00119)\end{array}$ & $\begin{array}{c}0.0237^{* * *} \\
(0.00130)\end{array}$ \\
\hline Age squared & & $\begin{array}{c}-0.000351^{* * *} \\
(0.0000179)\end{array}$ & $\begin{array}{c}-0.000348^{* * *} \\
(0.0000195)\end{array}$ \\
\hline Primary completed & & $\begin{array}{c}0.00571 \\
(0.00352)\end{array}$ & $\begin{array}{l}0.00966^{*} \\
(0.00378)\end{array}$ \\
\hline Secondary completed & & $\begin{array}{c}0.00581 \\
(0.00637)\end{array}$ & $\begin{array}{c}0.0101 \\
(0.00682)\end{array}$ \\
\hline University completed & & $\begin{array}{c}0.120^{* * *} \\
(0.0146)\end{array}$ & $\begin{array}{c}0.126^{* * *} \\
(0.0153)\end{array}$ \\
\hline Husband primary completed & & $\begin{array}{l}-0.00485 \\
(0.00312)\end{array}$ & $\begin{array}{c}-0.00231 \\
(0.00346)\end{array}$ \\
\hline Husband secondary completed & & $\begin{array}{c}-0.0122^{* *} \\
(0.00408)\end{array}$ & $\begin{array}{c}-0.00974^{*} \\
(0.00460)\end{array}$ \\
\hline Husband university completed & & $\begin{array}{c}-0.0409^{* * *} \\
(0.00469)\end{array}$ & $\begin{array}{c}-0.0385^{* * *} \\
(0.00527)\end{array}$ \\
\hline Husband absent & & $\begin{array}{l}0.00775 \\
(0.0164)\end{array}$ & $\begin{array}{l}0.00676 \\
(0.0167)\end{array}$ \\
\hline No. of children under 5 & & $\begin{array}{c}-0.0342^{* * *} \\
(0.00209)\end{array}$ & $\begin{array}{c}-0.0335^{* * *} \\
(0.00234)\end{array}$ \\
\hline Household migrated in past 5 years & & $\begin{array}{l}-0.00411 \\
(0.0125)\end{array}$ & $\begin{array}{l}-0.00271 \\
(0.0122)\end{array}$ \\
\hline Urban & & $\begin{array}{c}-0.114^{* * *} \\
(0.00687)\end{array}$ & $\begin{array}{c}-0.115^{* * *} \\
(0.00688)\end{array}$ \\
\hline Change in population density, 1990-2001 & & $\begin{array}{l}-0.0000276 \\
(0.0000622)\end{array}$ & $\begin{array}{c}0.0000433 \\
(0.0000524)\end{array}$ \\
\hline Consumption expenditures p.c., 1992/3 (in 1998 Dong) & & $\begin{array}{l}-0.0000162 \\
(0.0000202)\end{array}$ & $\begin{array}{c}-0.0000445^{*} \\
(0.0000209)\end{array}$ \\
\hline Proportion born in current village, 1997/8 & & $\begin{array}{l}0.0654^{*} \\
(0.0312)\end{array}$ & $\begin{array}{c}0.0317 \\
(0.0450)\end{array}$ \\
\hline Province literacy rate, 1999 & & $\begin{array}{l}-0.0190 \\
(0.0937)\end{array}$ & $\begin{array}{l}-0.163 \\
(0.141)\end{array}$ \\
\hline Proportion of HH with access to electricity, 1999 & & $\begin{array}{c}0.0469 \\
(0.0407)\end{array}$ & $\begin{array}{c}0.106 \\
(0.0630)\end{array}$ \\
\hline Proportion of land cultivated, 1999 & & $\begin{array}{c}0.00178^{*} \\
(0.000894)\end{array}$ & $\begin{array}{c}0.00275^{* * *} \\
(0.000499)\end{array}$ \\
\hline Year $=1999$ & $\begin{array}{c}-0.0478^{* * *} \\
(0.00717)\end{array}$ & $\begin{array}{c}-0.0475^{* * *} \\
(0.00683)\end{array}$ & $\begin{array}{c}-0.0464^{* * *} \\
(0.00738)\end{array}$ \\
\hline Year $=2009$ & $\begin{array}{c}0.0399^{* * *} \\
(0.00807)\end{array}$ & $\begin{array}{l}0.0191^{* *} \\
(0.00697)\end{array}$ & $\begin{array}{c}0.0198^{* *} \\
(0.00699)\end{array}$ \\
\hline Southern province & & & $\begin{array}{c}-0.112^{* * *} \\
(0.0289)\end{array}$ \\
\hline Observations & $3,701,971$ & $3,154,587$ & $3,154,587$ \\
\hline Mean Work & 0.85 & 0.85 & 0.85 \\
\hline Pseudo R Squared & 0.0754 & 0.1648 & 0.1560 \\
\hline
\end{tabular}

Marginal effects are presented. Region fixed effects are included in columns 1 and 2. Standard errors are clustered at the province level and shown in parentheses.

${ }^{*} p<0.05,{ }^{* *} p<0.01,{ }^{* * *} p<0.001$ 
rather than the levelling off of the impact of war. The idea is that, while at first women take their regional context to derive information and make a decision, leading to a divergence of FLFPR across provinces, at some point the learning effect will cross borders inducing a catching-up. This would mean that the effect of the conflict is not reduced from one generation to the other but it is less geographically bound and, consequently, no longer identifiable by statistical means.

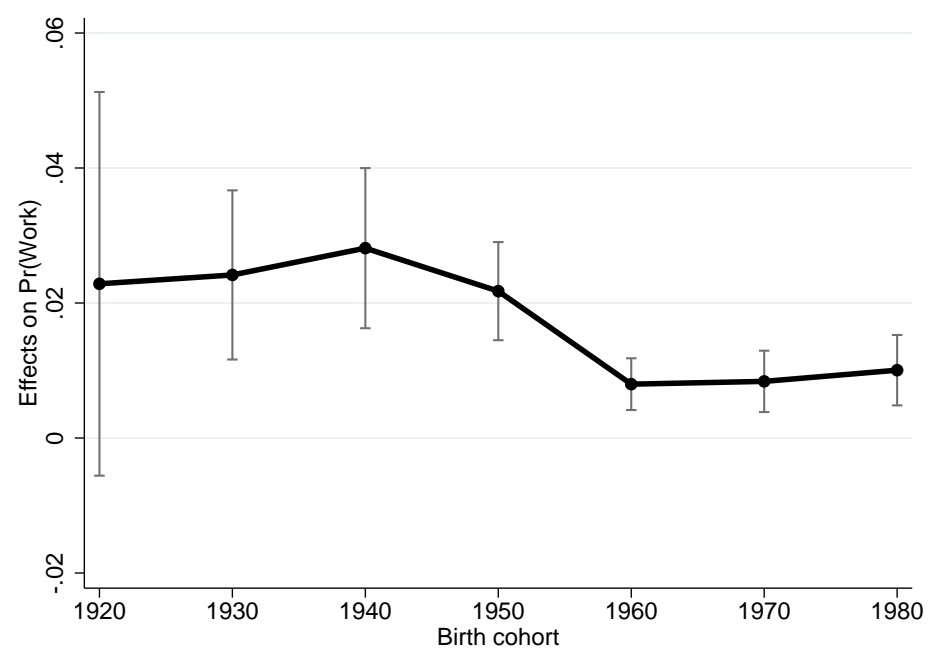

Figure 4.2: Marginal Effects Across Cohorts, Including 95\% Confidence Intervals

\subsubsection{The North-South Divide}

As was described in section 4.4, Vietnam is an interesting case for two reasons: FLFP was influenced by the war and the lack of male labour caused by it as shown above. Additionally, whether a woman lived and lives in the North or South of Vietnam matters as the timing of the introduction of communism differs which impacted the perception of working women in society. In terms of the model in section 4.3 this means that we expect $E_{t}$ to be larger (and thus the stigma to be smaller) for a longer period of time, even after the impact of violence has ceased. In the North, political considerations and reconstruction efforts drew women into the work force even after the end of the war.

In column 3 of Table 4.2, this is represented by the large and highly significant negative marginal effect of living in a Southern province. Just this geographical difference makes it 11.2 percentage points less likely that a woman will enter the labour force. Another descriptive argument in favour of this expectation is the observation that the average probability of a woman working across all three census waves is 91 per cent in the North and 78 per cent in the South, the average province FLFPR are 91 per cent and 77 per cent, respectively. Both these differences are statistically significant at the 1 per cent level. Additionally, region fixed effects provide 


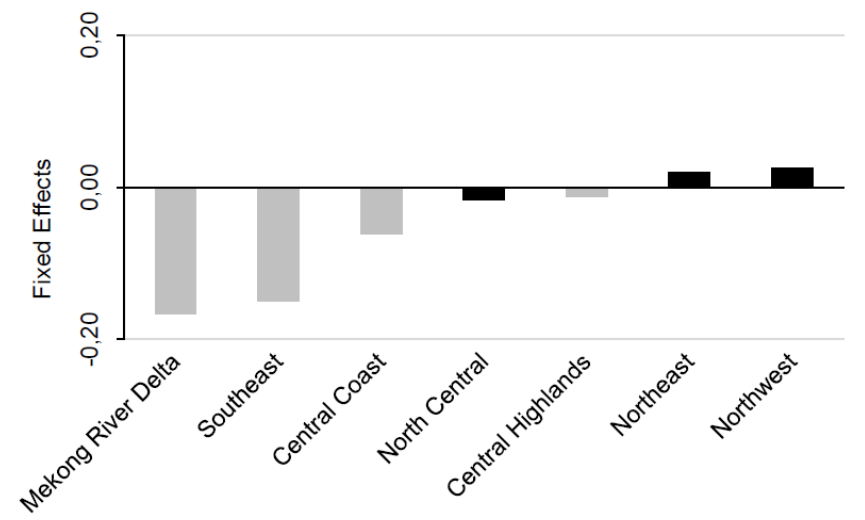

Figure 4.3: Region Fixed Effects (North = Black)

valuable information in this regard as they capture all the differences in FLFP that cannot be explained by any of the variables included in the models or over-time changes. ${ }^{61}$ Figure 4.3 shows the marginal effects of the region fixed effects from the main specification, the left out category being the Red River Delta which has the lowest mean FLFPR of all Northern regions. In contrast to the simple summary statistics, these are now conditional on all the factors controlled for in the specification. While the relationship is not perfect, it is striking that the positive fixed effects are all for Northern provinces, while with one close exception the negative ones are all of Southern regions. Especially for the South, the fixed effects are larger than the effect of 'missing men', underlining the longer-lasting impact of socialism on the Vietnamese society's attitude towards working women and, consequently, female labour force outcomes.

Summarising, we find a positive and lasting effect of conflict intensity measured by the share of females in the province population on women's labour market decisions. However, the impact is smaller for generations entering the labour market after the conflict ended as compared with those ones directly affected by the war. Having lived under a socialist system for longer, proxied by regions situated in the Northern part of the country, has played an even larger and more lasting role in shaping women's choice to enter the labour force.

\subsubsection{Tests for Robustness}

This section puts the findings above to several robustness tests. As described in section 4.5.1, a large number of Vietnamese migrated both within the country and abroad, voluntarily and involuntarily, both during and after the war. This could be one cause of spill-overs between provinces. We therefore take the average share of female population of the province itself and

\footnotetext{
${ }^{61}$ Gaddis and Klasen (2014) use a similar approach in their country level regression.
} 
two neighbouring areas as the explanatory variable. ${ }^{62}$ This is done in a way that we keep the same degree of variation with 47 values in our variable of interest, making sure to take varying combinations of neighbours. The results are very similar to the main findings: We estimate an overall positive effect of a higher share of females among the post-war population on women's likelihood to be part of the workforce. The marginal effect is now 0.0178 and thus of a similar size as above. Also the three groups, comprising of the women born in the 1920s to '40s, the 1950s cohort, and the women born during the 1960s to '80s are confirmed. However, now the interaction effects for the post-war generations (1960s onwards) are no longer statistically significantly different from zero.

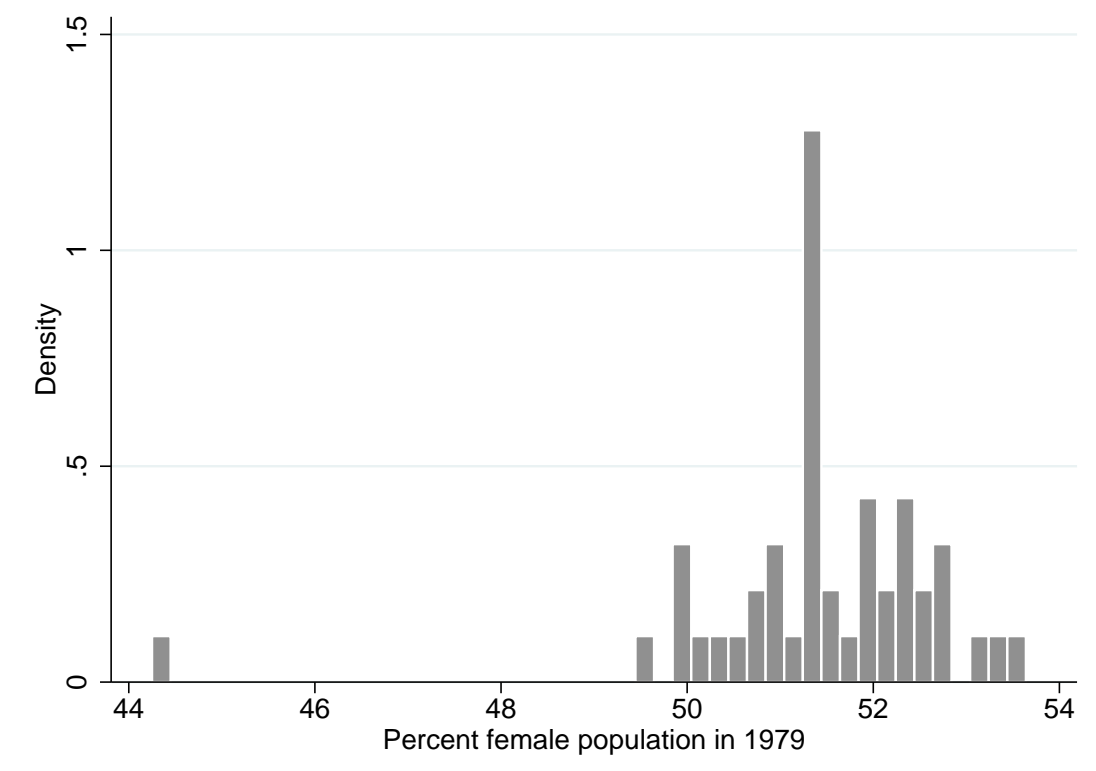

Figure 4.4: Distribution of Conflict Intensity

As the histogram of the conflict intensity variable in Figure 4.4 shows, there is one province which is a clear outlier in terms of female population, Quang Ninh. As a second robustness check, we thus drop observations from this province which again gives very similar results. ${ }^{63}$ The overall effect is positive and significant at the 1 per cent level (with a marginal effect of 0.014) and we find the three groups in terms of birth cohorts. Just as when averaging across neighbours, the 1960s to 1980s cohorts are no longer significantly affected by the war.

Overall, the robustness checks leave our results qualitatively unchanged although rather than displaying a small but significant effect of 'missing men' on generations entering working age after the war, we now find the effect to be confined to those women directly affected by the

\footnotetext{
${ }^{62}$ Results are presented in the appendix $\mathrm{C} 3$ and $\mathrm{C} 1$.

${ }^{63}$ Results without Quang Ninh province are presented in appendix C3 and C2.
} 
conflict.

\subsection{Conclusion}

This chapter analyses political and economic factors determining the decision of a woman to enter the labour market, namely the impact of 'missing men' due to mobilisation and an increased death toll during war and of living under a socialist regime. For the case of Vietnam, we find that conflict measured by the share of female population shortly after the end of the Vietnam War has a positive effect on the cohorts directly affected by it, i.e., those of working age during 1965 and '75. For younger generations, the effect is still positive but smaller and less robust. This indicates that while the absence of men in the household and in the labour force both pushed and pulled the women into market work, it only produced a muted long-term cultural change in perceptions regarding gender roles.

From our theoretical model in section 4.3 , which is motivated by the Vietnamese case but in principle valid more widely, it would also have been possible for the economic necessities of war to 'fast forward' cultural change. Yet it appears that norms need a more prolonged influence rather than just a short-term shock to change and otherwise have the tendency to fall back to the pre-crisis equilibrium (Ridd and Callaway 1987). In this case, the emergency lasted for ten years, stressing the extremely slow pace at which social norms evolve.

In Vietnam, the Northern half of the country has been under a socialist regime since the mid-1950s while this has only applied to the South since reunification in 1976. As socialist ideology has been significantly muted with the Doi Moi reforms in the course of the 1980s, its influence in the South is likely to be much more limited than in the North. Indeed, in our analysis we find that living in the North as such substantially increases the likelihood of a woman working. Thus, while the government actively supported women to enter the labour market in the Democratic Republic of Vietnam, twenty years also appear to be a time period more prone to have a lasting effect than the decade of war.

Of course, a mere regional binary variable is a rather crude measure for the exposure to socialism so that more research is needed in this direction. The division of the country offers an interesting natural experiment to exploit. Furthermore, although there is a growing literature on the effect of war on women, most of these conflicts are relatively recent so that it will be interesting to observe if the outcome of more women working in conflict-affected countries will still be visible in ten years or so (see for example Menon and van der Meulen Rodgers 2013 on Nepal).

While we suggest two channels for the relationship between conflict and FLFP in our theoretical 
model, this paper cannot say anything about their empirical validity - there is no information on whether or not the husband of a woman was involved in the conflict and the variable whether or not the mother of a woman in our sample worked has only very few observations. This would also be an interesting area of further research.

From a policy point of view, we conclude that shocks such as conflicts can catapult the society from one equilibrium to the next, represented by the increased labour force participation of women directly affected by the war. Well-formulated and well-timed reforms can stabilise the desired aspects of this new status quo as is visible in Northern Vietnam where a combination of economic dire straits and political ideology pulled and kept women in the workforce. 


\subsection{Appendix}

Table C1: Descriptive Statistics by Census Wave

\begin{tabular}{|c|c|c|c|c|c|c|c|c|c|c|c|c|c|c|c|}
\hline & \multicolumn{5}{|c|}{1989} & \multicolumn{5}{|c|}{1999} & \multicolumn{5}{|c|}{2009} \\
\hline & Min. & Max. & Mean & SD & $\mathrm{N}$ & Min. & Max. & Mean & $\mathrm{SD}$ & $\mathrm{N}$ & Min. & Max. & Mean & SD & $\mathrm{N}$ \\
\hline Working & 0 & 1 & 0.78 & 0.41 & 408877 & 0 & 1 & 0.77 & 0.42 & 416727 & 0 & 1 & 0.86 & 0.34 & 2876367 \\
\hline Percent female population in 1979 & 44 & 54 & 51.40 & 1.49 & 408877 & 44 & 54 & 51.44 & 1.33 & 416727 & 44 & 54 & 51.38 & 1.31 & 2876367 \\
\hline Total U.S. bombs, missiles, and rockets per km2 & 0 & 335 & 24.72 & 36.93 & 408877 & 0 & 335 & 26.72 & 47.47 & 416727 & 0 & 335 & 24.99 & 41.01 & 2876367 \\
\hline Age & 15 & 60 & 37.47 & 10.79 & 408877 & 15 & 60 & 38.13 & 9.86 & 416727 & 15 & 60 & 39.94 & 10.30 & 2876367 \\
\hline Less than primary completed & 0 & 1 & 0.53 & 0.50 & 407669 & 0 & 1 & 0.35 & 0.48 & 415672 & 0 & 1 & 0.36 & 0.48 & 2876221 \\
\hline Primary completed & 0 & 1 & 0.36 & 0.48 & 407669 & 0 & 1 & 0.46 & 0.50 & 415672 & 0 & 1 & 0.50 & 0.50 & 2876221 \\
\hline Secondary completed & 0 & 1 & 0.09 & 0.29 & 407669 & 0 & 1 & 0.16 & 0.37 & 415672 & 0 & 1 & 0.09 & 0.29 & 2876221 \\
\hline University completed & 0 & 1 & 0.02 & 0.15 & 407669 & 0 & 1 & 0.02 & 0.15 & 415672 & 0 & 1 & 0.05 & 0.22 & 2876221 \\
\hline Husband working & 0 & 1 & 0.69 & 0.46 & 408561 & 0 & 1 & 0.78 & 0.42 & 416690 & 0 & 1 & 0.82 & 0.38 & 2873158 \\
\hline Husband less than primary completed & 0 & 1 & 0.38 & 0.49 & 330548 & 0 & 1 & 0.27 & 0.44 & 359123 & 0 & 1 & 0.30 & 0.46 & 2529984 \\
\hline Husband $\mathrm{p}$ & 0 & 1 & 0.45 & 0.50 & 330548 & 0 & 1 & 0.51 & 0.50 & 359123 & 0 & 1 & 0.54 & 0.50 & 2529984 \\
\hline Husband secondary & 0 & 1 & 0.12 & 0.32 & 330548 & 0 & 1 & 0.18 & 0.38 & 359123 & 0 & 1 & 0.10 & 0.30 & 2529984 \\
\hline Husband university completed & 0 & 1 & 0.04 & 0.21 & 330548 & 0 & 1 & 0.05 & 0.22 & 359123 & 0 & 1 & 0.05 & 0.23 & 2529984 \\
\hline Husband absent & 0 & 1 & 0.10 & 0.30 & 408877 & 0 & 1 & 0.08 & 0.27 & 416727 & 0 & 1 & 0.08 & 0.27 & 2876367 \\
\hline No. of & 0 & 6 & 0.68 & 0.82 & 408877 & 0 & 5 & 0.39 & 0.62 & 416727 & 0 & 6 & 0.30 & 0.55 & 2876367 \\
\hline Household migrated in past 5 years & 0 & 1 & 0.03 & 0.18 & 408839 & 0 & 1 & 0.03 & 0.16 & 416652 & 0 & 1 & 0.02 & 0.15 & 2874596 \\
\hline Urban & 0 & 1 & 0.38 & 0.49 & 408877 & 0 & 1 & 0.50 & 0.50 & 416727 & 0 & 1 & 0.25 & 0.44 & 2876367 \\
\hline Province FLFPR & 0 & 1 & 0.76 & 0.13 & 408877 & 0 & 1 & 0.76 & 0.12 & 416727 & 1 & 1 & 0.86 & 0.10 & 2876367 \\
\hline Consumption expenditures p.c., 1992/3 (in 1998 Dong) & 1407 & 5454 & 2606.58 & 763.60 & 408877 & 1407 & 5454 & 2504.06 & 687.04 & 416727 & 1407 & 5454 & 2596.15 & 808.45 & 2876367 \\
\hline Proportion born in current village, $1997 / 8$ & 0 & 1 & 0.71 & 0.23 & 400047 & 0 & 1 & 0.74 & 0.21 & 410230 & 0 & 1 & 0.72 & 0.22 & 2821570 \\
\hline Province literacy ra & 1 & 1 & 0.88 & 0.08 & 408877 & 1 & 1 & 0.88 & 0.08 & 416727 & 1 & 1 & 0.89 & 0.08 & 2876367 \\
\hline Proportion of HH with access to electricity, 1999 & 0 & 1 & 0.74 & 0.20 & 408877 & 0 & 1 & 0.72 & 0.20 & 416727 & 0 & 1 & 0.73 & 0.20 & 2876367 \\
\hline Proportion of land cultivated, 1999 & 0 & 55 & 11.13 & 12.96 & 408877 & 0 & 55 & 11.13 & 12.18 & 416727 & 0 & 55 & 11.35 & 12.45 & 2876367 \\
\hline Southern province & 0 & 1 & 0.49 & 0.50 & 408877 & 0 & 1 & 0.46 & 0.50 & 416727 & 0 & 1 & 0.47 & 0.50 & 2876367 \\
\hline
\end{tabular}


Table C2: Determinants of Women's Choice to Work, Probit Models, 1989-2009, Including Cohort Interaction Effects

\begin{tabular}{|c|c|}
\hline & $(1)$ \\
\hline Percent female population in 1979 & $\begin{array}{c}0.0660 \\
(0.0417)\end{array}$ \\
\hline 1930s Birth cohort & $\begin{array}{l}-0.482 \\
(1.203)\end{array}$ \\
\hline 1940s Birth cohort & $\begin{array}{l}-1.310 \\
(1.302)\end{array}$ \\
\hline 1950s Birth cohort & $\begin{array}{c}-0.901 \\
(1.581)\end{array}$ \\
\hline 1960s Birth cohort & $\begin{array}{l}1.380 \\
(2.312)\end{array}$ \\
\hline 1970s Birth cohort & $\begin{array}{l}1.006 \\
(2.600)\end{array}$ \\
\hline 1980s Birth cohort & $\begin{array}{c}0.871 \\
(2.357)\end{array}$ \\
\hline Interaction 1930s cohort & $\begin{array}{c}0.0109 \\
(0.0234)\end{array}$ \\
\hline Interaction 1940s cohort & $\begin{array}{c}0.0292 \\
(0.0254)\end{array}$ \\
\hline Interaction 1950s cohort & $\begin{array}{c}0.0248 \\
(0.0309)\end{array}$ \\
\hline Interaction 1960 s cohort & $\begin{array}{c}-0.0181 \\
(0.0450)\end{array}$ \\
\hline Interaction 1970s cohort & $\begin{array}{c}-0.0125 \\
(0.0505)\end{array}$ \\
\hline Interaction 1980s cohort & $\begin{array}{c}-0.0114 \\
(0.0458)\end{array}$ \\
\hline Year $=1999$ & $\begin{array}{c}-0.282^{* * *} \\
(0.0317)\end{array}$ \\
\hline Year $=2009$ & $\begin{array}{c}0.0195 \\
(0.0350)\end{array}$ \\
\hline Observations & 3144828 \\
\hline Pseudo R Squared & 0.167 \\
\hline
\end{tabular}


Table C3: Determinants of Women's Choice to Work: Robustness Checks, Probit Models, 1989-2009

\begin{tabular}{|c|c|c|}
\hline Percent female population in 1979 & $\begin{array}{c}(1) \\
0.0178^{* *} \\
(0.00669)\end{array}$ & $\begin{array}{c}(2) \\
0.0140^{* *} \\
(0.00511)\end{array}$ \\
\hline Age & $\begin{array}{l}0.0239^{* * *} \\
(0.00120)\end{array}$ & $\begin{array}{c}0.0238^{* * *} \\
(0.00121)\end{array}$ \\
\hline Age squared & $\begin{array}{c}-0.000351^{* * *} \\
(0.0000181)\end{array}$ & $\begin{array}{c}-0.000349^{* * *} \\
(0.0000183)\end{array}$ \\
\hline Primary completed & $\begin{array}{c}0.00630 \\
(0.00353)\end{array}$ & $\begin{array}{c}0.00632 \\
(0.00353)\end{array}$ \\
\hline Secondary completed & $\begin{array}{c}0.00631 \\
(0.00629)\end{array}$ & $\begin{array}{c}0.00705 \\
(0.00645)\end{array}$ \\
\hline University completed & $\begin{array}{l}0.120^{* * *} \\
(0.0145)\end{array}$ & $\begin{array}{l}0.120^{* * *} \\
(0.0150)\end{array}$ \\
\hline Husband primary completed & $\begin{array}{l}-0.00462 \\
(0.00311)\end{array}$ & $\begin{array}{l}-0.00406 \\
(0.00308)\end{array}$ \\
\hline Husband secondary completed & $\begin{array}{l}-0.0114^{* *} \\
(0.00408)\end{array}$ & $\begin{array}{c}-0.0121^{* *} \\
(0.00409)\end{array}$ \\
\hline Husband university completed & $\begin{array}{c}-0.0406^{* * *} \\
(0.00465)\end{array}$ & $\begin{array}{c}-0.0411^{* * *} \\
(0.00472)\end{array}$ \\
\hline Husband absent & $\begin{array}{l}0.00842 \\
(0.0163)\end{array}$ & $\begin{array}{l}0.00714 \\
(0.0167)\end{array}$ \\
\hline No. of children under 5 & $\begin{array}{c}-0.0342^{* * *} \\
(0.00211)\end{array}$ & $\begin{array}{c}-0.0343^{* * *} \\
(0.00213)\end{array}$ \\
\hline Household migrated in past 5 years & $\begin{array}{l}-0.00372 \\
(0.0124)\end{array}$ & $\begin{array}{l}-0.00314 \\
(0.0126)\end{array}$ \\
\hline Urban & $\begin{array}{l}-0.114^{* * *} \\
(0.00710)\end{array}$ & $\begin{array}{l}-0.113^{* * *} \\
(0.00680)\end{array}$ \\
\hline Change in population density, 1990-2001 & $\begin{array}{l}-0.0000558 \\
(0.0000681)\end{array}$ & $\begin{array}{l}-0.0000230 \\
(0.0000697)\end{array}$ \\
\hline Consumption expenditures p.c., 1992/3 (in 1998 Dong) & $\begin{array}{l}-0.0000158 \\
(0.0000213)\end{array}$ & $\begin{array}{l}-0.0000177 \\
(0.0000219)\end{array}$ \\
\hline Proportion born in current village, $1997 / 8$ & $\begin{array}{l}0.0621^{*} \\
(0.0304)\end{array}$ & $\begin{array}{l}0.0634^{*} \\
(0.0314)\end{array}$ \\
\hline Province literacy rate, 1999 & $\begin{array}{l}-0.0439 \\
(0.0915)\end{array}$ & $\begin{array}{l}-0.0232 \\
(0.0934)\end{array}$ \\
\hline Proportion of HH with access to electricity, 1999 & $\begin{array}{c}0.0459 \\
(0.0391)\end{array}$ & $\begin{array}{c}0.0449 \\
(0.0400)\end{array}$ \\
\hline Proportion of land cultivated, 1999 & $\begin{array}{c}0.00174^{*} \\
(0.000879)\end{array}$ & $\begin{array}{c}0.00179^{*} \\
(0.000898)\end{array}$ \\
\hline Year $=1999$ & $\begin{array}{c}-0.0468^{* * *} \\
(0.00692)\end{array}$ & $\begin{array}{c}-0.0463^{* * *} \\
(0.00692)\end{array}$ \\
\hline Year $=2009$ & $\begin{array}{l}0.0199^{* *} \\
(0.00690)\end{array}$ & $\begin{array}{l}0.0209^{* *} \\
(0.00692)\end{array}$ \\
\hline $\begin{array}{l}\text { Observations } \\
\text { Pseudo R Squared }\end{array}$ & $\begin{array}{c}3,154,587 \\
0.1637\end{array}$ & $\begin{array}{c}3,090,756 \\
0.1652\end{array}$ \\
\hline \multicolumn{3}{|c|}{$\begin{array}{l}\text { In column 1, the female share of population is averaged over three provinces. } \\
\text { In column 2, the outlier Quang Ninh province is dropped. } \\
\text { Marginal effects are presented. Region fixed effects are included. } \\
\text { Standard errors are clustered at the province level and presented in parentheses } \\
{ }^{*} p<0.05,{ }^{* *} p<0.01,{ }^{* * *} p<0.001\end{array}$} \\
\hline
\end{tabular}




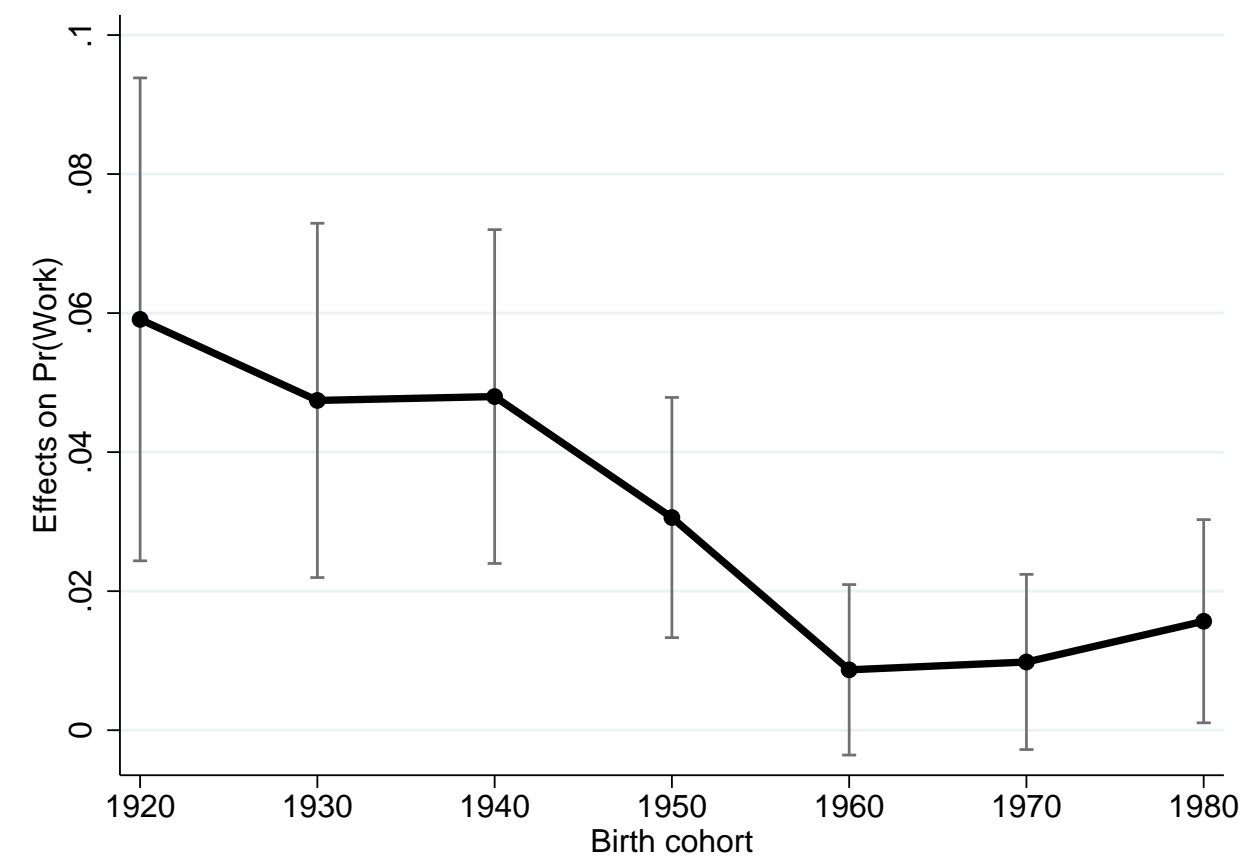

Figure C1: Marginal Effects Across Cohorts, Averaging Over Three Provinces, Including 95\% Confidence Intervals

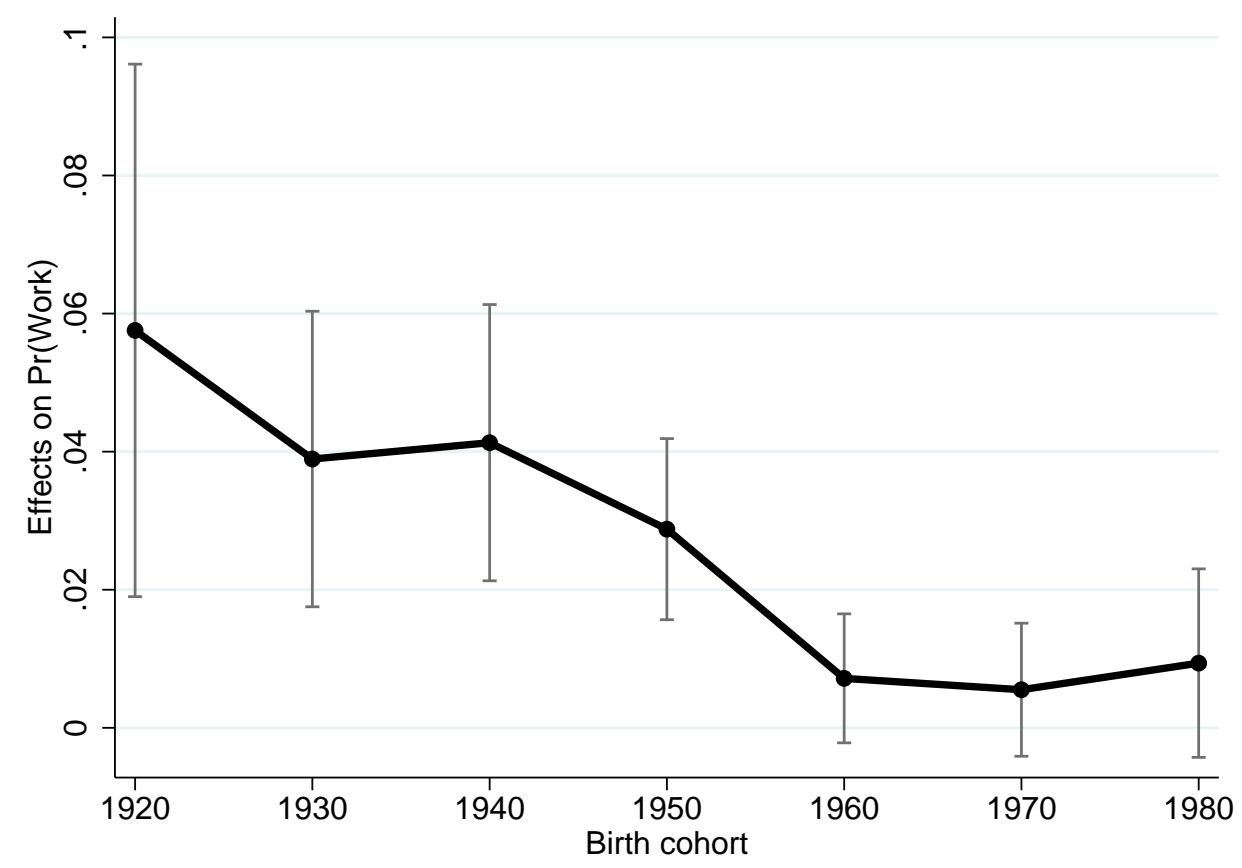

Figure C2: Marginal Effects Across Cohorts, Dropping Quang Ninh Province, Including 95\% Confidence Intervals 


\section{Bibliography}

Abadie, A. (2005). Poverty, Political Freedom, and the Roots of Terrorism. American Economic Review, 95:50-56.

Abrahms, M. (2012). The Political Effectiveness of Terrorism Revisited. Comparative Political Studies, 45:366-393.

Acemoglu, D., Autor, D. H., and Lyle, D. (2004). Women, War, and Wages: The Effect of Female Labor Supply on the Wage Structure at Midcentury. Journal of Political Economy, 112(3):497-551.

Afrobarometer $(2002,2005,2010)$. Afrobarometer Uganda: Waves 2, 3, and 4.5. Accessible on http://www.afrobarometer.org.

Agblorti, S. K. (2011). Refugee Integration in Ghana: The Host Community's Perspective. New Issues in Refugee Research Research Paper, 203.

Ai, C. and Norton, E. C. (2003). Interaction Terms in Logit and Probit Models. Economics Letters, 80:123-129.

Akbulut-Yuksel, M., Khamis, M., and Yuksel, M. (2011). Rubble Women: The Long-Term Effects of Postwar Reconstruction on Female Labor Market Outcomes. IZA DP, 6148.

Akresh, R. and De Walque, D. (2008). Armed Conflict and Schooling: Evidence from the 1994 Rwandan Genocide. Households in Conflict Network (HiCN) Working Paper, 47.

Akresh, R., Verwimp, P., and Bundervoet, T. (2011). Civil War, Crop Failure, and Child Stunting in Rwanda. Economic Development and Cultural Change, 59:777-810.

Alesina, A., Giuliano, P., and Nunn, N. (2011a). Fertility and the Plough. American Economic Review, 101(3):499-503.

Alesina, A., Giuliano, P., and Nunn, N. (2013). On the Origins of Gender Roles: Women and the Plough. The Quarterly Journal of Economics, 128(2):469-530.

Alesina, A., Ichino, A., and Karabarbounis, L. (2011b). Gender-Based Taxation and the Division of Family Chores. American Economic Journal: Economic Policy, 40:1-40.

Alix-Garcia, J. and Saah, D. (2009). The Effect of Refugee Inflows on Host Communities: Evidence from Tanzania. The World Bank Economic Review, 24(1):148-170.

Amin, S. and Alam, I. (2008). Women's Employment Decisions in Malaysia: Does Religion Matter? The Journal of Socio-Economics, 37(6):2368-2379. 
Antecol, H. (2000). An Examination of Cross- Country Differences in the Gender Gap in Labor Force Participation Rates. Labour Economics, 7(4):409-426.

Asal, V., Brown, M., and Schulzke, M. (2015). Kill Them All - Old and Young, Girls and Women and Little Children: An Examination of the Organizational Choice of Targeting Civilians. Political Science Research and Methods, forthcoming.

Asal, V., Deloughery, K., and Phillips, B. J. (2012). When politicians sell drugs: Examining why middle east ethnopolitical organizations are involved in the drug trade. Terrorism and Political Violence, 24(2):199-212.

Asal, V., Legault, R., Szekely, O., and Wilkenfeld, J. (2013). Gender ideologies and forms of contentious mobilization in the middle east. Journal of Peace Research, 50(3):305-318.

Asal, V., Pate, A., and Wilkenfeld, J. (2008). Minorities at Risk Organizational Behavior Data and Codebook Version 9/2008. Accessible on http://www.cidcm.umd.edu/mar/data.asp.

Asal, V. and Wilkenfeld, J. (2013). Ethnic conflict: An organizational perspective. Penn State Journal of Law and International Affairs, 2(1):91-102.

Ashenfelter, O. (1980). Unemployment as Disequilibrium in a Model of Aggregate Labor Supply. Econometrica, 48(3):547-564.

Baez, J. E. (2011). Civil Wars Beyond Their Borders: The Human Capital and Health Consequences of Hosting Refugees. Journal of Development Economics, 96(2):391-408.

Beresford, M. (2008). Doi Moi in Review: The Challenges of Building Market Socialism in Vietnam. Journal of Contemporary Asia, 38(2):221-243.

Berry, L. (2008). The Impact of Environmental Degradation on Refugee-Host Relations: A Case Study from Tanzania. New Issues in Refugee Research Research Paper, 151.

Besley, T. and Persson, T. (2009). The Incidence of Civil War: Theory and Evidence . Economic Organisation and Public Policy Programme Working Paper, EOPP/2009/5.

Besley, T. and Persson, T. (2011). The Logic of Political Violence. The Quarterly Journal of Economics, 126:1411-1445.

Bhalotra, S. and Umaña-Aponte, M. (2010). The Dynamics of Women's Labour Supply in Developing Countries. IZA DP, 4879.

Blattman, C. (2009). From Violence to Voting: War and Political Participation in Uganda. American Political Science Review, 103:231-247. 
Blattman, C. and Miguel, E. (2010). Civil war. Journal of Economic Literature, 48:3-57.

Boserup, E. (1970). Women's Role in Economic Development. St. Martin, New York.

Bravo, A. and Dias, C. (2006). An Empirical Analysis of Terrorism: Deprivation, Islamism and Geopolitical Factors. Defence and Peace Economics, 17:329-341.

Brück, T. and Schindler, K. (2009). The Impact of Violent Conflicts on Households: What Do We Know and What Should We Know about War Widows? Oxford Development Studies, 37(3):289-309.

Brück, T. and Schindler, K. (2011). The Effects of Conflict on Fertility in Rwanda. German Institute for Economic Research Discussion Paper, 1143.

Buis, M. (2010). Stata Tip 87: Interpretation of Interactions in Non-Linear Models. The Stata Journal, 10:305-308.

Bunck, J. M. (1997). Women and Post-Cold War Socialism: The Cases of Cuba and Vietnam. In Cuba in Transition: Volume 7, pages 21-31, Miami, Florida.

Byenkya, K. (2012). Uganda and the Danger of Veiled Bantustans. http://www.compareafrique.com/uganda-and-the-danger-of-veiled-bantustans, accessed April 9, 2014.

Cagatay, N. and Özler, S. (1995). Feminization of the Labor Force: The Effects of Long- Term Development and Structural Adjustment. World Development, 23(11):1883-1894.

Carter, D. (2012). A Blessing or a Curse? State Support for Terrorist Groups. International Organization, 66:129-151.

Carter, D. (2014). Territoriality, Non-State Actors, and Military Strategy. Paper presented at the Terrorism and Policy Conference 2014.

Cassar, A., Grosjean, P., and Whitt, S. (2013). Legacies of Violence: Trust and Market Development. Journal of Economic Growth, 18:285-318.

Chambers, R. (1986). Hidden Losers? The Impact of Rural Refugees and Refugee Programs on Poorer Hosts. International Migration Review, 20(2):245-263.

Chulov, M. (2009). Kurds Lay Claim to Oil Riches in Iraq as Old Hatreds Flare. The Guardian/ The Observer. http://www.theguardian.com/world/2009/jun/14/kurds-iraq-kirkuk-oil, accessed on May 9, 2014. 
Clark, C. R. (2008). Borders of Everyday Life: Congolese Young People's Political Identification in Contexts of Conflict-Induced Displacement. Households in Conflict Network (HiCN) Working Paper, 38.

Clark, K. and Summers, L. (1982). Labour Force Participation: Timing and Persistence. Review of Economic Studies, 49(5):825-844.

Clark, R., Ramsbey, T. W., and Stier Adler, E. (1991). Culture, Gender, and Labor Force Participation: A Cross-National Study. Gender and Society, 5(1):47-66.

Collier, P. (2008). The Bottom Billion - Why the Poorest Countries are Failing and What Can Be Done About It. Oxford University Press, Oxford.

Collier, P. and Hoeffler, A. (1998). On Economic Causes of Civil War. Oxford Economic Papers, 50:563-573.

Collier, P. and Hoeffler, A. (2004). Greed and Grievance in Civil War. Oxford Economic Papers, 56:563-595.

Collier, P., Hoeffler, A., and Rohner, D. (2009). Beyond Greed and Grievance: Feasibility and Civil War. Oxford Economic Papers, 61:1-27.

Conteh-Morgan, E. (2003). Collective Political Violence: An Introduction to the Theories and Cases of Violent Conflicts. Routledge, New York, London.

Corfield, J. (2008). The History of Vietnam. The Greenwood Histories of Modern Nations. Greenwood Press, Westport, Connecticut.

Crisp, J. (2003). No Solutions in Sight: The Problem of Protracted Refugee Situations in Africa. New Issues in Refugee Research Research Paper, 75.

De Luca, G. and Verpoorten, M. (2011). From Vice to Virtue? Civil War and Social Capital in Uganda. Households in Conflict Network (HiCN) Working Paper, 111.

De Soysa, I. and Binningsb $\varnothing$, H. (2009). The Devil's Excrement as Social Cement: Natural Resources and Political Terror, 1980-2002. International Social Science Journal, 57:981-1002.

De Soysa, I. and Neumayer, E. (2007). Resource Wealth and the Risk of Civil War Onset: Results from a New Dataset of Natural Resource Rents, 1970-1999. Conflict Management and Peace Science, 24:201-218.

Denny, E. and Walter, B. (2014). Ethnicity and Civil War. Journal of Peace Research, 51:199212. 
Dolan, P., Peasgood, T., and White, M. (2008). Do We Really Know What Makes Us Happy? A Review of the Economic Literature on the Factors Associated with Subjective Well-Being. Journal of Economic Psychology, 29:94-122.

Dreher, A. and Fischer, J. (2012). Government Decentralization as a Disincentive for Transnational terror? An Empirical Analysis. International Economic Review, 51:981-1002.

Dryden-Peterson, S. and Hovil, L. (2003). Local Integration as a Durable Solution: Refugees, Host Populations and Education in Uganda. New Issues in Refugee Research Research Paper, 93.

Dryden-Peterson, S. and Hovil, L. (2004). A Remaining Hope for Durable Solutions: Local Integration of Refugees and Their Hosts in the Case of Uganda. Refuge, 22(1):26-38.

Duranton, G. and Maystadt, J.-F. (2013). The Development Push of Refugees : Evidence from Tanzania. Presented at the Households in Conflict Network Workshop, 20-22 November 2013 at the University of California Berkeley.

Einhorn, B. (1995). Introduction. In Einhorn, B. and Yeo, E. J., editors, Women and Market Societies: Crisis and Opportunity, pages 1-8. Edward Elgar Pub, Aldershot.

Enders, W., G.A., H., and Sandler, T. (2014). The Changing Nonlinear Relationship between Income and Terrorism. Journal of Conflict Resolution, forthcoming.

Enders, W. and Sandler, T. (2012). The Political Economy of Terrorism. Cambridge University Press, Cambridge.

Farré, L. and Vella, F. (2013). The Intergenerational Transmission of Gender Role Attitudes and its Implications for Female Labour Force Participation. Economica, 80(318):219-247.

Fearon, J. and Laitin, D. (2003). Ethnicity, Insurgency, and Civil War. American Political Science Review, 97:75-90.

Feldmann, H. (2007). Protestantism, Labor Force Participation, and Employment Across Countries. American Journal of Economics and Sociology, 66(4):795-816.

Fernàndez, R. (2007). Women, Work, and Culture. Journal of the European Economic Association, 5(2-3):305-332.

Fernàndez, R. (2013). Cultural Change as Learning: The Evolution of Female Labor Force Participation over a Century. American Economic Review, 103(1):472-500. 
Fernàndez, R. and Fogli, A. (2009). Culture: An Empirical Investigation of Beliefs, Work, and Fertility. American Economic Journal: Macroeconomics, 1(1):146-177.

Fernàndez, R., Fogli, A., and Olivetti, C. (2004). Mothers and Sons: Preference Formation and Female Labor Force Dynamics. The Quarterly Journal of Economics, 119(4):1249-1299.

Fielden, A. (2008). Local Integration: An Under-Reported Solution to Protracted Refugee Situations. New Issues in Refugee Research Research Paper, 158.

Findley, M. and Young, J. (2012). Terrorism and Civil War: A Spatial and Temporal Approach to a Conceptual Problem. Perspectives on Politics, 10:285-305.

Fogli, A. and Veldkamp, L. (2011). Nature or Nurture? Learning and the Geography of Female Labor Force Participation. Econometrica, 79(4):1103-1138.

Fortin, N. M. (2005). Gender Role Attitudes and the Labour-market Outcomes of Women across OECD Countries. Oxford Review of Economic Policy, 21(3):416-438.

Fortna, V. P. (2014). Do Terrorists Win? The Use of Terrorism and Civil War Outcomes 1989-2009. International Organization, forthcoming.

Freedom House (2014). Freedom in the World. Country and Territory Ratings and Status. Accessible on http://www.freedomhouse.org/report-types/freedom-world.

Gaddis, I. and Klasen, S. (2014). Economic Development, Structural Change, and Womens Labor Force Participation: A Reexamination of the Feminization U Hypothesis. Journal of Population Economics, 27:639-681.

Gaibulloev, K. and Sandler, T. (2014). An Empirical Analysis of Alternative Ways that Terrorist Groups End. Public Choice, 106:25-44.

Garimoi Orach, C. (2005). Integrating Refugee and Host Health Services in West Nile Districts, Uganda. Health Policy and Planning, 21(1):53-64.

Gassebner, M. and Luechinger, S. (2011). Lock, Stock, and Barrel: A Comprehensive Assessment of the Determinants of Terror. Public Choice, 149:235-261.

Gilligan, M. J., Pasquale, B. J., and Samii, C. D. (2014). Civil War and Social Cohesion: Lab-in-the-Field Evidence from Nepal. American Journal of Political Science, 58:604-619.

Goldin, C. (1991). The Role of World War II in the Rise of Women's Employment. The American Economic Review, 81(4). 
Goldin, C. (1994). The U-Shaped Female Labor Force Function in Economic Development and Economic History. NBER Working Paper, 4707.

Goodkind, D. (1995). Rising Gender Inequality in Vietnam Since Reunification. Pacific Affairs, $68(3): 342-359$.

Guiso, L., Sapienza, P., and Zingales, L. (2003). People's Opium? Religion and Economic Attitudes. Journal of Monetary Economics, 50(1):225-282.

Gustafsson, S. (1992). Separate Taxation and Married Women's Labor Supply: A Comparison of West Germany and Sweden. Journal of Population Economics, 5:61-85.

Gustafsson, S., Wetzels, C. M., Vlasbom, J. D., and Dex, S. (1996). Women's Labor Force Transitions in Connection with Childbirth: A Panel Data Comparison between Germany, Sweden and Great Britain. Journal of Population Economics, 9:223-246.

Hadnes, M. and Roggemann, H. (2014). My Risk - You Pay: Group Identity and Risk Sharing in an Ethnically Diverse Society. Presented at the Development Economics Research Group Goettingen, 14 May 2014.

Hazan, M. and Maoz, Y. D. (2002). Women's Labor Force Participation and the Dynamics of Tradition. Economics Letters, 75:193-198.

Hirschman, C., Preston, S., and Vu, M. L. (1995). Vietnamese Casualties During the American War: A New Estimate. Population and Development Review, 21(4):783-812.

Horn, M. (2010). Giant Oil and Gas Fields of the World. Accessible on http://www.datapages.com/Partners/AAPGGISPublicationsCommittee/GISOpenFiles/HornGiantFields.as

Humphreys, M. (2005). Natural Resources, Conflict, and Conflict Resolution: Uncovering the Mechanisms. Journal of Conflict Resolution, 49:508-537.

Hunziker, P. and Cederman, L.-E. (2012). No Extraction without Representation: Petroleum Production and Ethnonationalist Conflict. APSA 2012 Annual Meeting Paper.

Ibànez, A. (2001). El Salvador: War and Untold Stories - Women Guerillas. In Moser, C. and Clark, F., editors, Victims, perpetrators or actors? Gender, armed conflict and political violence, pages 117-130. Zed Books, London.

International Organization for Migration (2013). Migration in Uganda - A Rapid Country Profile 2013. Geneva, Switzerland. 
Jacobsen, K. (1996). Factors Influencing the Policy Responses of Host Governments to Mass Refugee Influxes. International Migration Review, 30(3):655-678.

Jacobsen, K. (2001). The Forgotten Solution: Local Integration for Refugees in Developing Countries. New Issues in Refugee Research Research Paper, 45.

Jacobsen, K. (2002). Can Refugees Benefit the State? Refugee Resources and African Statebuilding. Journal of Modern African Studies, 40(4):577-596.

Jaeger, U. (2010). Working or Stay-at-Home Mum? The Influence of Family Benefits and Religiosity. Ifo Working Paper, 84.

Justino, P. (2008). The Impact of Armed Civil Conflict on Household Welfare and Policy Responses. Background Paper for the World Economic and Social Survey 2008.

Justino, P. (2009). Poverty and Violent Conflict: A Micro-Level Perspective on the Causes and Duration of Warfare. Journal of Peace Research, 46(3):315-333.

Kaiser, T. (2000). UNHCR's Withdrawal from Kiryandongo: Anatomy of a Handover. New Issues in Refugee Research Research Paper, 32.

Kaiser, T. (2006). Between a Camp and a Hard Place: Rights, Livelihood and Experiences of the Local Settlement System for Longterm Refugees in Uganda. Journal of Modern African Studies, 44(4):597-621.

Karl, T. (2007). Oil-Led Development: Social, Political, and Economic Consequences. Encyclopedia of Energy, 4:661-672.

Keen, D. (2008). Complex Emergencies. Polity Press, Cambridge.

Kevane, M. and Wydick, B. (2001). Social Norms and the Time Allocation of Women's Labor in Burkina Faso. Review of Development Economics, 5(1):119-129.

Kibreab, G. (1985). African Refugees: Reflections on the African Refugee Problem. Africa World Press, Trenton, New Jersey, USA.

Kirui, P. and Mwaruvie, J. (2012). The Dilemma of Hosting Refugees: A Focus on the Insecurity in North-Eastern Kenya. International Journal of Business and Social Science, 3(8):161-171.

Klasen, S. (1994). Human Development and Women's Lives in a Restructured Eastern Bloc: Lessons from the Developing World. In Schipke, A. and Taylor, A. M., editors, The Economics of Transformation: Theory and Practice in the New Market Economies. Springer, Berlin, Heidelberg. 
Klasen, S. and Lamanna, F. (2009). The Impact of Gender Inequality in Education and Employment on Economic Growth: New Evidence for a Panel of Countries. Feminist Economics, 15(3):91-132.

Klasen, S. and Pieters, J. (2015). What Explains the Stagnation of Female Labor Force Participation in Urban India. The World Bank Economic Review, forthcoming.

Kornai, J. (1992). The Socialist System: The Political Economy of Communism. Princeton University Press, Princeton, NJ.

Kydd, A. H. and Walter, B. F. (2006). The Strategies of Terrorism. International Security, $31(1): 49-80$.

Leech, G. (2004). The War on Terror in Colombia. Colombia Journal, 54.

Lehrer, E. L. (1995). The Effects of Religion on the Labor Supply of Married Women. Social Science Research, 24:281-301.

Lohmann, S. (2015). Information Technologies and Subjective Well-Being: Does the Internet Raise Material Aspirations? Oxford Economic Papers, forthcoming.

Lundberg, S. (1985). The Added Worker Effect. Journal of Labor Economics, 3(1):11-37.

Mammen, K. and Paxson, C. (2000). Women's Work and Economic Development. The Journal of Economic Perspectives, 14(4):141-164.

Marshall, M., Gurr, T., and Jaggers, K. (2014). Polity IV Project, Political Regime Characteristics and Transitions, 1800-2013. Accessible on http://www.systemicpeace.org/inscrdata.html.

Maystadt, J.-F. and Verwimp, P. (2014). Winners and Losers Among a Refugee-Hosting Population. Economic Development and Cultural Change, 61:789-823.

McKenzie, D. J. (2004). Aggregate Shocks and Urban Labor Market Responses: Evidence from Argentina's Financial Crisis. Economic Development and Cultural Change, 52(4):719-758.

Meierrieks, D. and Krieger, T. (2014). The Roots of Islamist Armed Struggle. Paper presented at the Terrorism and Policy Conference 2014.

Menon, N. and van der Meulen Rodgers, Y. (2013). War and Women's Work: Evidence from the Conflict in Nepal. Journal of Conflict Resolution, 59(1):51-73.

Mickolus, E., Sandler, T., Murdock, J., and Flemming, P. (2004). International Terrorism: Attributes of Terrorist Events (ITERATE): 1968 - 2003, Data Codebook. 
Miguel, E. and Roland, G. (2011). The Long-Run Impact of Bombing Vietnam. Journal of Development Economics, 96:1-15.

Miguel, E., Satyanath, S., and Sergenti, E. (2004). Economic Shocks and Civil Conflict: An Instrumental Variables Approach. Journal of Political Economy, 112:725-753.

Mincer, J. (1962). Labor Force Participation of Married Women: A Study of Labor Supply. In Groves, H. M., editor, Aspects of Labor Economics, pages 63-106. Princeton University Press.

Montalvo, J. and Reynal-Querol, M. (2005). Ethnic Polarization, Potential Conflict, and Civil Wars. American Economic Review, 95:796-816.

Montalvo, J. G. and Reynal-Querol, M. (2007). Fighting against Malaria: Prevent Wars while Waiting for the 'Miraculous' Vaccine. The Review of Economics and Statistics, 89(1):165-177.

Muller, E. N. and Seligson, M. A. (1987). Inequality and Insurgency. The American Political Science Review, 81:425-452.

NOAA National Geophysical Data Center and US Air Force Weather Agency (2011). DMSP-OLS Nighttime Lights Time Series, Version 4. Accessible on http://ngdc.noaa.gov/eog/download.html.

Päivi, L., Rød, J., and Thieme, N. (2007). Fighting over Oil: Introducing A New Dataset. Conflict Management and Peace Science, 24:239-256.

Parker, S. W. and Skoufias, E. (2004). The Added Worker Effect over the Business Cycle: Evidence from Urban Mexico. Applied Economics Letters, 11(10):625-630.

Priebe, J. (2010). Child Costs and the Causal Effect of Fertility on Female Labor Supply: An investigation for Indonesia 1993-2008. Courant Research Centre: Poverty, Equity and Growth - Discussion Papers, 45.

Prieto-Rodrìguez, J. and Rodrìguez-Gutiérrez, C. (2003). Participation of Married Women in the European Labor Markets and the 'Added Worker Effect'. The Journal of Socio-Economics, $32(4): 429-446$.

Puerto Gomez, M. and Christensen, A. (2010). The Impacts of Refugees on Neighboring Countries: A Development Challenge. Technical report.

Rabe-Hesketh, S., Skrondal, A., and Pickles, A. (2004). Generalized Multilevel Structural Equation Modelling. Psychometrika, 69:167-190. 
Raleigh, C., Linke, A., Hegre, H., and Karlsen, J. (2010). Introducing ACLED-Armed Conflict Location and Event Data. Journal of Peace Research, 47(5):1-10.

Ranis, G. (2012). Vertical and Horizontal Decentralization and Ethnic Diversity in Sub-Saharan Africa. Yale University Economics Department Working Paper, 108.

Refugee Law Project (2008). Consolidated Report on the Field Visits by the Legal Aid and Counseling Department to Kyangwali Refugee Settlement 3-15 August 2007 and 10-22 June 2008 .

Regan, P. and Norton, D. (2005). Greed, Grievance, and Mobilization in Civil Wars. Journal of Conflict Resolution, 49:319-336.

Republic of Uganda (2000). Uganda Participatory Poverty Assessment Report. Technical report, Ministry of Finance, Planning and Economic Development.

Ridd, R. and Callaway (1987). Women and Political Conflict: Portraits of Struggle in Times of Crisis. New York University Press, New York.

Rohner, D., Thoenig, M., and Zilibotti, F. (2013). Seeds of Distrust: Conflict in Uganda. Journal of Economic Growth, 18:217-252.

Ross, M. (2004). How Do Natural Resources Influence Civil War? Evidence from Thirteen Cases. International Organization, 58:35-67.

Ross, M. (2013). Oil and Gas Data, 1932-2011. Accessible on http://thedata.harvard.edu/dvn/dv/mlross.

Ross, M. L. (2008). Oil, Islam, and Women. American Political Science Review, 102(01).

Rowley, E. A., Burnham, G. M., and Drabe, R. M. (2006). Protracted Refugee Situations: Parallel Health Systems and Planning for the Integration of Services. Journal of Refugee Studies, 19(2):158-186.

Ruiz, I. and Vargas-Silva, C. (2013). The Economics of Forced Migration. The Journal of Development Studies, 49(6):772-784.

Salehyan, I. and Gleditsch, K. S. (2006). Refugees and the Spread of Civil War. International Organization, 60(02):335-366.

Sambanis, N. (2004). What Is Civil War? Conceptual and Empirical Complexities of an Operational Definition. Journal of Conflict Resolution, 48:814-858. 
Sambanis, N. (2008). Terrorism and Civil War. In Terrorism, Economic Development, and Political Openness. Cambridge University Press, Cambridge.

Sandler, T. (1995). On the Relationship between Democracy and Terrorism. Terrorism and Political Violence, 7:1-9.

Schindler, K. (2010). Who Does What in a Household after Genocide? Evidence from Rwanda. German Institute for Economic Research Discussion Paper, 1072.

Schneider, L. (2014). Media Freedom Indices: What They Tell Us - And What They Dont. Edition DW Akademie 01/2014.

Seguino, S. (2000). Accounting for Asian Economic Growth: Adding Gender to the Equation. Feminist Economics, 6(3):27-58.

Serneels, P. and Verpoorten, M. (2012). The Impact of Armed Conflict on Economic Performance: Evidence from Rwanda. IZA Discussion Paper, 6737.

Shemyakina, O. N. (2015). Exploring the Impact of Conflict Exposure during Formative Years on Labor Market Outcomes in Tajikistan. Journal of Development Studies, forthcoming.

Sorenson, J. (1994). African Refugees: Development Aid and Repatriation. Westview Press, Boulder, Colorado, USA.

Sribney, W. (1996). Does Stata Provide a Test for Trend? http://www.stata.com/support/faqs/statistics/test-for-trend/, accessed December 27, 2013.

Stanton, J. (2013). Terrorism in the Context of Civil War. Journal of Politics, pages 1-14.

Stewart, F. (1993). War and Underdevelopment: Can Economic Analysis Help Reduce the Costs? Journal of International Development, 5(4):357-380.

Tam, H. (2011). U-Shaped Female Labor Participation with Economic Development: Some Panel Data Evidence. Economics Letters, 110:140-142.

Tarrow, S. (1998). Power in Movement: Social Movements and Contentious Politics. Cambridge University Press, Cambridge.

Tavares, J. (2004). The Open Society Assesses its Enemies: Shocks, Disasters and Terrorist Attacks. Journal of Monetary Economics, 51:1039-1070.

Turley, W. S. (1972). Women in the Communist Revolution in Vietnam. Asian Survey, $12(9): 793-805$. 
Tuyen, N. N. (1999). Transitional Economy, Technological Change and Women's Employment: The Case of Vietnam. Gender, Technology and Development, 3(1):43-64.

Ugandan Bureau of Statistics (2002, 2005, 2010). Uganda National Household Survey. Accessed through: Minnesota Population Center. Integrated Public Use Microdata Series, International: Version 6.3.

Ugandan Bureau of Statistics (2011). District Population Profile 2011. Accessible on http://www.ubos.org.

United Nations High Commissioner for Refugees (2005). Conclusion on Local Integration. Geneva, Switzerland.

United Nations High Commissioner for Refugees (2013). UNHCR Website. http://unhcr.org, accessed June 15, 2013.

United Nations High Commissioner for Refugees (2014). UNHCR Statistical Yearbook 2013. Geneva, Switzerland.

United Nations High Commissioner for Refugees and Intergovernmental Authority on Development (2010). HIV Behavioural Surveillance Survey (BSS): Kyaka II Refugee Settlement and Surrounding Host Community.

van Biesebroeck, J. (2010). Wages Equal Productivity. Fact or Fiction? Evidence from Sub Saharan Africa. World Development, 39:1333-1346.

Verwimp, P. (2012). Undernutrition, Subsequent Risk of Mortality and Civil War in Burundi. Economics \& Human Biology, 10:221-231.

Vietnamese General Statistics Office (1982). Report on the 1979 Population and Housing Census. Ha Noi, Vietnam.

Vietnamese General Statistics Office (1989, 1999, 2009). Population and Housing Census. Accessed through: Minnesota Population Center. Integrated Public Use Microdata Series, International: Version 6.3.

Voors, M. J., Nillesen, E. E. M., Verwimp, P., Bulte, E. H., Lensink, R., and van Soest, D. P. (2012). Violent Conflict and Behavior: A Field Experiment in Burundi. American Economic Review, 102(2):941-964.

Weber, M. (1905). The Protestant Ethic andThe Spirit of Capitalism. George Allen \& Unwin Ltd., London. 
Werker, E. (2002). Refugees in Kyangwali Settlement: Constraints on Economic Freedom. Refugee Law Project Working Paper, 7.

Werner, J. (1981). Women, Socialism, and the Economy of Wartime North Vietnam, 1960 1975. Studies in Comparative Communism, 14(2-3):165-190.

Whitaker, B. E. (2002). Refugees in Western Tanzania: The Distribution of Burdens and Benefits Among Local Hosts. Journal of Refugee Studies, 15(4):339-358.

Wimmer, A. (2002). From Subject to Object of History. The Kurdish Movement in Northern Iraq since 1991. Kurdische Studien, 2:115-129.

Wimmer, A., Cederman, L.-E., and Min, B. (2009). Ethnic Politics and Armed Conflict. A Configurational Analysis of a New Global Dataset. American Sociological Review, 74:316-337.

Wood, E. J. (2008). The Social Processes of Civil War: The Wartime Transformation of Social Networks. Annual Review of Political Science, 11(1):539-561.

World Bank (2011a). 2011 World Development Report on Conflict, Security. and Development. Washington DC.

World Bank (2011b). 2012 World Development Report on Gender Equality and Development. Washington DC.

World Bank (2015). World Development Indicators. http://data.worldbank.org/products/wdi, accessed April 3, 2015.

World Values Survey Association (2001). World Values Survey (Wave 4). Accessible on http://www.worldvaluessurvey.org.

Yeoh, E. (2012). Ethnic Fractionalization: The World, China and Malaysia in Perspective. China-ASAEN Perspective Forum, 2:161-206. 


\section{Eidesstattliche Erklärung}

\section{Versicherung gemäß $§ 16$ Prüfungs- und Studienordnung für den Promotionsstudiengang Wirtschaftswissenschaften}

1. Die Gelegenheit zum vorliegenden Promotionsvorhaben ist mir nicht kommerziell vermittelt worden. Insbesondere habe ich keine Organisation eingeschaltet, die gegen Entgelt Betreuerinnen und Betreuer für die Anfertigung von Dissertationen sucht oder die mir obliegenden Pflichten hinsichtlich der Prüfungsleistungen für mich ganz oder teilweise erledigt.

2. Ich versichere, dass ich die eingereichte Dissertation "Microeconomic Analyses of the Causes and Consequences of Political Violence" selbstständig und ohne unerlaubte Hilfsmittel verfasst habe; fremde Hilfe habe ich dazu weder unentgeltlich noch entgeltlich entgegengenommen und werde dies auch zukünftig so halten. Anderer als der von mir angegebenen Hilfsmittel und Schriften habe ich mich nicht bedient. Alle wörtlich oder sinngemäß den Schriften anderer Autoren entnommenen Stellen habe ich kenntlich gemacht.

3. Die Richtlinien zur Sicherung der guten wissenschaftlichen Praxis an der Universität Göttingen werden von mir beachtet.

4. Eine entsprechende Promotion wurde an keiner anderen Hochschule im In- oder Ausland beantragt; die eingereichte Dissertation oder Teile von ihr wurden nicht für ein anderes Promotionsvorhaben verwendet.

5. Des Weiteren ist mir bekannt, dass Unwahrhaftigkeiten hinsichtlich der vorstehenden Erklärung die Zulassung zur Promotion ausschließen bzw. später zum Verfahrensabbruch oder zur Rücknahme des erlangten Titels berechtigen.

Datum, Unterschrift 